
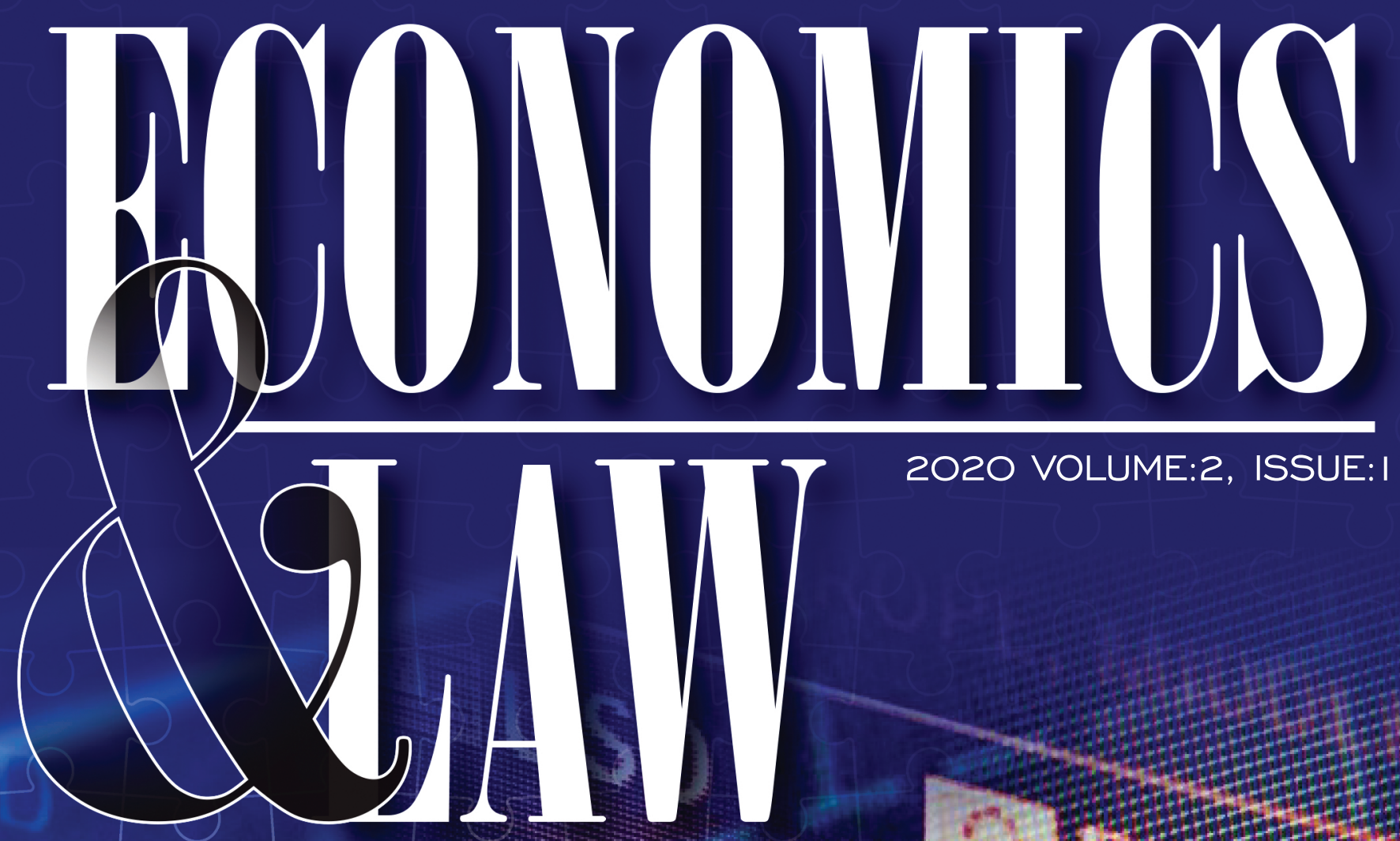

2020 VOLUME:2, ISSUE: I
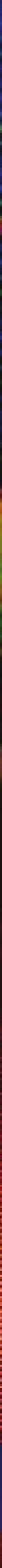


\section{Editor-in-Chief}

prof. Maria Kicheva, Ph.D., SWU “Neofit Rilski”, Bulgaria

\section{Deputy Chief Editor}

Vladislav Krastev, Ph.D., SWU “Neofit Rilski”, Bulgaria

\section{Editorial Board}

prof. Paul Leonard Gallina,

Ph.D., Williams School of Business, Bishop's University Sherbrooke, Québec, Canada

prof. José António Conceição Santos,

The School of Management, Hospitality and Tourism of the University of Algarve, Portugal

assoc. prof. Preslav Dimitrov, Ph.D.,

SWU "Neofit Rilski”, Bulgaria

prof. Dimitar Dimitrov, Ph.D.,

SWU “Neofit Rilski”, Blagoevgrad, Bulgaria

assoc. prof. Nikolay Marin, Ph.D.,

SWU “Neofit Rilski”, Blagoevgrad, Bulgaria

prof. d-r of Sc. Valeri Lazarov

SWU “Neofit Rilski”, Blagoevgrad, Bulgaria

assoc. prof. Yuliana Mladenova Mateeva, Ph.D.,

Varna Free University, Bulgaria

assoc. prof. Andriyana Andreeva, Ph.D.,

University of Economics - Varna, Bulgaria

prof. dr of Economic Sc. Stanka Tonkova,

University of National and World Economy, Bulgaria

prof. Gancho Ganchev, Ph.D.,

SWU "Neofit Rilski”, Bulgaria

assoc. prof. Almaz Kadyraliev, Ph.D.,

Musa Ruskulbekov Kyrgyz Economic University

assoc. prof. dr. of Economic Sc. Bakas Bakhtiyar uulu,

Musa Ruskulbekov Kyrgyz Economic University

assoc. prof. Tran Van Hoa, Ph.D.,

Hue University, Vietnam

assoc. prof. Truong Tan Quan, Ph.D.,

Hue University, Vietnam

Pham Xuan Hung, Ph.D.,

Hue University, Vietnam 
prof. Farhad Sariev, Ph.D.,

K. Tynystanov Issyk-Kul State University, Kyrgyzstan

prof. Maksat Erkimbaev, Ph.D.,

K. Tynystanov Issyk-Kul State University, Kyrgyzstan

assoc. prof Svetlana Sirmbard, Ph.D.,

Adam University, Kyrgyzstan

prof. dr. of Technical Sc. Abdyrakhman Subankulovich Mavlyanov, Adam University, Kyrgyzstan

prof. dr. of Economic Sc. Almakuchukov Keneshbek Mukashevich, Adam University, Kyrgyzstan

assoc. prof. Dimitris Aidonis, Ph.D.,

Technological Educational Institute of Central Macedonia at Serres

assoc. prof. Dimitris Folinas, Ph.D.,

Technological Educational Institute of Central Macedonia at Serres

chief. assist. prof. Petar Parvanov, Ph.D.,

SWU "Neofit Rilski”, Bulgaria

chief. assist. prof. Katarina Valaskova, Ph.D.,

University of Zilina, Slovakia

chief. assist. prof. Pavol Durana, Ph.D.,

University of Zilina, Slovakia 


\section{CONTENT}

THE „HAWALA SYSTEM“ - BETWEEN CUSTOMARY LAW AND ORGANIZED CRIME...p. 1 Ivan Geshev

Nikolay Marin

CONSTITUTIONAL AND FINANCIAL LEGAL ASPECTS OF THE STATE BUDGET IN THE

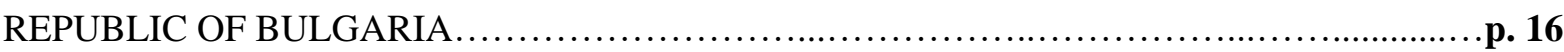

Valentina Goleva

Vesela Mircheva

COMPUTER TECHNOLOGY AND EHEALTH. TRENDS AND REGULATORY

FRAMEWORK.

p. 43

Andriyana Andreeva

Galina Yolova

Diana Dimitrova

THE ENTERPRISE MEMORY IN KNOWLEDGE MANAGEMENT OF MODERN

ORGANIZATION

p. 49

Larisa Shemyatikhina

CHALLENGES AND OPPORTUNITIES FOR SOCIAL ENTERPRISES

.p. 55

Mariela Bogdanova

STRATEGIES AND POLICIES WITHIN THE CONTEXT OF SUSTAINABLE DEVELOPMENT OF INDUSTRIAL ENTERPRISES

.p. 62

Gergana Yocheva

METHODS FOR TERMINATION OF EMPLOYMENT CONTRACTS IN THE BULGARIAN PRIVATE SECTOR.

Boryana Milusheva

JAPAN'S POLICY AGAINST THE CRIME OF STALKING.

p. 78

Nikol Nikolova

SOME ISSUES OF THE PROCEEDINGS UNDER ARTICLE 66 OF THE ADMINISTRATIVE PROCEDURE CODE IN THE CONTEXT OF THE ACTIVITY CARRIED OUT BY THE FARMERS p. 88

Svetlana Tsonchovska 


\title{
THE „HAWALA SYSTEM“ - BETWEEN CUSTOMARY LAW AND ORGANIZED CRIME
}

\author{
Ivan Geshev ${ }^{1}$ \\ Nikolay Marin ${ }^{2}$ \\ СИСТЕМАТА „ХАВАЛА“ - МЕЖДУ ОБИЧАЙНОТО ПРАВО И \\ ОРГАНИЗИРАНАТА ПРЕСТЬПНОСТ \\ ИВАН ГЕШЕВ \\ НИКОЛАЙ МАРИН
}

\begin{abstract}
The article aims to reveal the nature and specifics of the alternative method of modern banking 'Hawala', which makes it on the one hand, extremely convenient for use by organized criminal groups, and on the other, difficult to be investigated and proven. The authors trace Hawala's historical roots, referring to the ancient customary law, and point out the strict rules on which it operates. It highlights that, with the development of information technologies, the Hawala systems' principles have found a new application, from which organized criminal groups benefit. The article clarifies how the Bulgarian legislation incriminates money laundering and the possible use of the 'Hawala' system for this and other criminal activities. Attention is paid to the Bulgarian experience in the investigation of a network of persons involved in the use of the Hawala method for concealing, particularly serious crimes. The conclusion is made that the Hawala phenomenon poses a serious threat to the rule of law in any country, and the Bulgarian legislation needs to be adapted in order to provide effective mechanisms to counter such non-conventional type of crime.
\end{abstract}

Keywords: Hawala system, customary law, alternative methods of transferring funds, organized groups, money laundering

JEL Codes: $K 15$, F50

\section{Историческо развитие на системата „Хавала“}

В историческите извори съществуват сведения, че банковите и подобните на тях операции имат своите корени още от древността. Така например, банкови операции, макар и в опростен вид, са съществували още от древността в Египет. Свидетелство, че вид банкова и разплащателна дейност е била позната и във Вавилон и Асирия, е Сборникът от закони на Хамурапи $(1792$ - 1750 г. пр. Хр.), който също съдържа данни за използване на платежни средства в гражданските отношения. С развитието на

${ }^{1}$ Ivan Geshev is Prosecutor General of Republic of Bulgaria. PhD candidate in "International Law and International Relations" at "Law and History Faculty", South-West University "Neofit Rilski", Blagoevgrad, Bulgaria, ivdida@gmail.com

ORCID iDhttps://orcid.org/0000-0002-3078-0875

2 Assoc. prof. Nikolay Marin, PhD. Dean of "Law and History Faculty”, South-West University "Neofit Rilski", Blagoevgrad, Bulgaria, marin@law.swu.bg

ORCID iDhttps://orcid.org/0000-0001-5461-6546

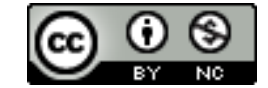

This work is licensed under a Creative Commons Attribution-NonCommercial 4.0 International License. 
обществените отношения на гражданския, а също и на търговския, оборот тези способи са били усъвършенствани и постепенно достигат вида, в който ги познаваме днес. Класическите банкови операции в днешно време се ползват с висока степен на доверие поради тяхната надеждност и достъпност. Същевременно обаче тези трансакции се характеризират в общия случай и с високо равнище на прозрачност и проследимост, което ги прави непривлекателни за определена категория субекти на правото, които по една или друга причина целят да избегнат същата тази прозрачност и проследимост на изпращаните или получаваните от тях парични средства. Причините за това могат да са много, но в общия случай се касае за стремеж към прикриване на определена незаконна дейност - укриване на доходи за целите на данъчното облагане, пране на пари, финансиране на организираната престьпност или тероризма и т.н. В резултат постепенно в съвременния свят се появяват нови методи за непроследимо или трудно проследимо „банкиране”, като типичен пример в тази насока са криптовалутите, където трансакциите отново могат да са анонимни.

Съществуват неформални системи за парични преводи. Тяхното наименование често е различно в зависимост от редица културни фактори и обичаи от географския регион, в който оперират - hawala, hundi, hawilaad и др. Тяхната същност е сходна и според Страхилова (2019), Алдимиров (2017) и Chene (2008) често се отьждествява с „подземно банкиране“, „нелегални банкови канали“ или „мрежи за целите на организираната престьпност“.

Най-известната от тях е системата „Хавала“. Думата има арабски корени и означава „превеждам”, „телеграфирам”, а често и “доверие”. Зараждането на системата може да бъде проследено до древността, като не може да се посочи или обособи някакъв конкретен период, в който е започнала да функционира. Данни за такива операции се откриват както в арабския свят, така и в Азия, а дори и във Филипините.

\section{Неформалната система „Хавала“ - функционираща и изградена въз основа на обичайното право в Близкия Изток}

По своята същност „Хавала“ представлява алтернативен метод на съвременно банкиране, който се използва на основата на културни традиции и обичаи и оперира извън банковата и финансовата система. Това нейно качество я прави трудноопределима като правен институт, именно защото тази дейност се развива извън поставените от законодателството изисквания и рамки, при която липсват писмени правила, приложими към нея. В тази връзка, заслужава да бъде споделено становището на Pathak (2003), който изследва опита на САЩ, трудностите и препятствията пред правната уредба на „Хавала“, определяйки нейната същност, основаваща се на културни традиции и норми.

Следва да се подчертае, че в България, например, банковата дейност се извършва само при наличието на определени изисквания, свързани с конкретен вид правноорганизационна форма - акционерно дружество, минимален капитал, който при учредяването му е не по-малък от 10 млн. лева съгласно Закона за кредитните институции (ЗКИ), чл. 7 , ал. 2 , и задължително лицензиране за извършване на банкова дейност от Българска народна банка. Същевременно, твърде наивно би било да се смята, че явление от такъв комплексен характер съществува, без да е подчинено на определени правила, които се спазват от участниците в него. Именно тази характеристика налага функционирането на „Хавала“ на основата на обичаите, известни в доктрината като обичайно право - система от неписани правила, чието продължително прилагане е създало у участниците съзнание за тяхната задължителност. Характерна особеност на „Хавала“ е принципът на доверие и широкото използване на роднински или приятелски връзки, посредством които се създава мрежа, покриваща различни региони. 
Така, за разлика от съвременното банкиране, „Хавала“ не се базира на установена по надлежния ред система за извършване на банкови преводи, нито пък използва публично известна и достъпна материална база (например банкови офиси и други подобни). Вместо това паричните преводи се извършват в рамките на неофициална и анонимна мрежа от лица (наричани хаваладари), които приемат и предават паричните средства в брой. На практика, посредством използването на този метод се постига трансакция на определена парична сума от едно място на друго, без реално предадените пари да бъдат изпращани на това място. По същество това практически се реализира като едно лице предава определена парична сума на приемащия я хаваладар с указания за данните за друго лице, което трябва да получи „превода”. Тук следва да се има предвид, че за разлика от класическия банков превод, не е необходимо, (а и едва ли и се практикува) предоставянето на пълния набор от лични данни на получателя или пък произход на средствата, както посочва в своя автореферат Алдимиров (2017).

Впоследствие хаваладарьт предава данните на получателя на друг хаваладар, участник в системата (като не се извършва физическо предаване на паричните суми между хаваладарите), който оперира на територията, на която следва да бъдат получени парите. Последният, от своя страна, предава сумата на посоченото от приемащия хаваладар лице. Какви са отношенията на самите хаваладари и как те уреждат помежду си това имуществено разместване е трудно да се определи и бихме могли само да предполагаме, тъй като официални данни, статистики или пък „общи условия” за това не са достьпни. Отново приложимо ще е обичайното право, но теорията все още не познава явлението достатъчно добре, за да определи със сигурност какви точно са прилаганите между самите хаваладари правила и обичаи и дали те са валидни за различните региони, или има отграничения между тях. Още повече, че дори по някакъв начин да бъде установено как определени лица, част от системата „Хавала“, са уредили отношенията помежду си, то не може да се достигне до извод, че това е универсалният принцип, приложим и във всички останали случаи. Причината за това, от една страна, се корени в липсата на писмени правила, а от друга, в обстоятелството, че за да се установи съществуването на определен обичай, са необходими множество сведения от различни източници.

Самото предаване на паричните средства на получателя им се случва единствено въз основа на легитимация на последния като надлежен получател на сумата. Както обаче посочихме по-горе, под легитимация не следва да се разбира класическият смисъл на понятието. Именно, защото „Хавала“ преследва анонимност и цели непроследимост, е напълно възможно, а и често практикувано, самоличността на получателя на сумата да остане скрита. Вместо това легитимацията се извършва посредством легитимационен код, предоставен от приемащия сумата хаваладар. Този код се предоставя на лицето, което следва да получи сумата и на лицето, участник в системата „Хавала“, което следва да я предаде. По този начин се създава хипотеза, в която се извършва паричен превод, без реално паричните средства да се преместват от едно място на друго, без да е известна причината, т.е. основанието за този превод, и дори без да е известна самоличността на който и да било от участващите в него лица. Този превод не оставя каквато и да било документна следа, което допълнително усложнява работата на правохранителните органи и на органите на съдебната власт, особено когато чрез системата „Хавала“ се извършва или се осуетява разкриването на престьпления. 


\section{дейности \\ Прилагане на системата „Хавала“ с цел пране на пари и други престыпни}

Прането на пари и други ценности, както е посочено в Работен документ относно изпирането на пари (2013) е предмет на уредба както от гледна на международното публично право, така и в законодателствата на голям брой държави благодарение на Конвенцията на ООН срещу транснационалната организирана престьпност (2000). В тази връзка в законодателството на Република България прането на пари, респективно на други ценности, е квалифицирано като противоправно деяние, в резултат на което и законодателят е предвидил санкции, форми и ред за борба с този вид престьпност. Този законодателен стремеж е намерил израз в Закона за мерките срещу изпирането на пари (ЗМСИП). Това ясно личи от самите цели, поставени от чл. 1 от ЗМСИП - създаването на мерки за превенция на изпирането на пари и организация и контрол по тяхното изпълнение. От своя страна, изпирането на пари е намерило своята легална дефиниция в чл. 2 от ЗМСИП, ал.1, от т.1 до т. 4. Цитираната разпоредба квалифицира като изпиране на пари (поставяйки изискването за наличие на умисьл) следните действия:

В т. 1 - Преобразуване или прехвърляне на имущество, със знанието, че това имущество е придобито от престьпление или от акт на участие в престъпление. Поставя се и изискване за специална цел на това преобразуване - същото да е извършено, за да бъде укрит или прикрит незаконният произход на имуществото или за да се подпомогне лице, което участва в извършването на такова действие с цел да се избегнат правните последици от деянието на това лице.

В т. 2 - Укриване или прикриване на естеството, източника, местонахождението, разположението, движението, правата по отношение на или собствеността върху имущество. Отново е налице и специално изискване по отношение на субективния елемент - наличие на знание, че това имущество е придобито от престьпление или от акт на участие в престьпление.

В т. 3 - Придобиване, владение, държане или използване на имущество със знание към момента на получаването, че е придобито от престъпление или от акт на участие в престьпление. Тук знанието за противозаконния характер на имуществото следва да е налице към момента да получаването.

На последно място, в т. 4 като изпиране на пари се квалифицира и участието в което и да е от предходните действия, сдружаването с цел извършване на такова действие, опитът за извършване на такова действие, както и подпомагането, подбуждането, улесняването или даването на съвети при извършването на такова действие. Изпиране на пари ще е налице и когато горепосочените действия са извършени за прикриване на пране на пари, макар и извършителят да не е взел каквото и да било участие в самото им изпиране (ЗМСИП).

По същество изпирането на пари е сложна, добре и последователно организирана престъпна дейност, изискваща отлично познаване на вида и размера на благата, които в резултат от определени действия да позволят тяхното легализиране. Заслужава да бъде споделено разбирането на представители на правната доктрина, че „изпирането на пари може накратко да бъде определено като заключителен етап от развитието на незаконна икономическа дейност, представляващ процес на навлизане на облагите от нея в законната икономика под привидността на законен капитал, годен да бъде усвояван в нея като законна икономическа полза" (Пушкарова, И., 2014, с. 2).

Като самостоятелна хипотеза на изпиране на пари е уреден случаят, когато престъплението, от което е придобито такова имущество, е извършено в друга държава членка на ЕС или в трета държава и не попада под юрисдикцията на Република България. 
От така даденото определение на понятието „пране на пари“ е видно, че характерните белези на системата „Хавала“ я правят предпочитано средство за финансиране на терористични организации или организирани престъпни групи, укриване на доходи и пране на пари или други ценности. Често „Хавала”, която съществува отдавна в някои райони на Централна Азия, Южна Азия и Близкия Изток, дори много преди съвременното банкиране да започне да функционира, е културна традиция, според която хората в тези райони превеждат пари чрез традиционния хавала механизъм. Системата е особено удобна за население, което е извън обсега на официалния финансов сектор. Често то живее в бедни и отдалечени райони, където не е оправдано да се създава и развива мрежа от местни банкови клонове (например в Сомалия, Непал, Пакистан). Според доклад на неправителствена организация Adeso (2012) в политически нестабилните райони като Сомалия, „Хавала” представлява един от най-удобните и надеждни методи за трансфериране на средства, тъй като за разлика от други системи, при които са ангажирани редица изпълнители и подизпълнители, при нея се редуцира рискът от подмяна на паричната сума, защото последната „преминава през по-мальк брой ръце“.

В много развити страни подобни канали се използват предимно от мигрантите поради споделените сходни обичаи, начин на живот и език между клиенти и хаваладари.

На пръв поглед, системата изглежда с ниска степен на надеждност, тъй като практически изпращачът на сумата просто я предава на хаваладара, без за това да получи документ и без възможност да реализира по съдебен ред правата си, в случай че хаваладарът не изпълни задълженията си. На практика обаче системата „Хавала“ (макар и оперираща на доверие) действа с висока ефективност и има изключително широко приложно поле дори в региони, в които тя не е съществувала доскоро. Това ясно говори за наличието на управление и вътрешен контрол в рамките на системата, които осигуряват нейното функциониране.

В принципен план „Хавала“ предоставя и определени предимства и улеснения спрямо банкирането, които обуславят използването й за посочените цели. Така например, за да бъде извършен банков превод, абсолютна предпоставка е наличието на регистрирана банкова сметка на получателя, който да е сключил договор със съответната банкова институция (в много страни се изисква и наличието на банкова сметка на изпращача на сумата), в който договор са посочени в пълнота неговите лични данни. Очевидно това не е необходима предпоставка за използването на услугите на хаваладара.

Същевременно тази система преодолява трудностите с конвертиране на валути и вниманието, което би привлякло подобно конвертиране в големи размери, ако същото бъде извършено по надлежния ред. Така например, ако изпращачът на сумата се намира на територията на държава, намираща се в Азия, разполага с местна валута и желае да изпрати на получател в Република България сума в български левове, то тяхното набавяне от изпращача би било трудно или най-малкото скъпо начинание. Този проблем се преодолява в рамките на системата „Хавала“, където най-често тази конверсия се извършва от самите хаваладари.

Таксите, начислявани от агентите на „Хавала““ при прехвърлянето на средства, са значително по-ниски от тези, заплащани в банки и други форми за превод на средства. Това често се дължи главно на минималните режийни разходи, освен това лихвите са забранени съгласно Шариата. За да насьрчат валутните преводи чрез тяхната система, хаваладарите понякога освобождават емигрантите от плащането на такси. За разлика от тях, те съобщават по-високи такси на тези, които използват системата, за да избегнат административния контрол или за стимулиране на престьпни актове. Според El-Qorchi 
(2002) тези по-високи такси често покриват всички разходи на хаваладарите. В публикувания доклад „ТTe Role of Hawala and Other Similar Service Providers in Money Laundering and Terrorist Financing“ (2013) за потребителите на „Хавала” таксите варират в диапазона от 0.1 до $0.5 \%$. За сравнение с банковата система, размерите за превод на средства е с по-висока стойност.

На следващо място, системата „Хавала“ разкрива висока ефективност и във времево отношение, което затруднява допълнително установяване на трансакцията и често прави практически невъзможно нейното предотвратяване. Така поради липсата на необходимост от каквито и да било регистрации и физическо преместване на парични средства е напълно възможно сумата по превода да бъде получена от крайния си адресат в рамките на часове. Причината за това е, че единственото, което е необходимо на получателя, за да получи в брой определената парична сума, е да се легитимира пред изплащащото я лице - например с определен код. Този код приемащият хаваладар съобщава в момента на приемането на сумата, при което е налице теоретичната възможност адресата на превода, легитимирайки се със съобщения му код, веднага да получи сумата.

Така системата „Хавала“ позволява анонимно прехвърляне на парични средства в брой, без ограничение за размера на сумите, без държавни регулации за начина на превода, без съставянето на каквито и да било документи за извършения превод и без посочване на неговото основание.

Според изследователя Chene (2008) системата „Хавала” придобива популярност и значимост за обществото поради две основни причини:

- липса на ефективна банкова система;

- $\quad$ много хора предпочитат да извършват парични преводи в брой чрез нея, тъй като според тях тя представлява традиционният начин на трансакция.

\section{„Хавала” и новите информационни технологии}

С развитието на технологиите принципите на действие на системата „Хавала” намират ново приложение, от което се възползват организираните престъпни групи. Съществуват редица проучвания, които доказват, че блокчейн технологията представлява съвременна „Хавала” система. Според Alsubaie (2017) системата „Хавала” е сходна с децентрализирана peer-to-peer мрежа. Блокчейн също е децентрализирана технология. Всичко, което се случва в нея, е функция на мрежата като цяло и се базира на доверието между потребителите в системата. Използвайки процес, наречен криптография, купувачът на един актив, получател на съответната валута, може да потвърди самоличността на продавача/подателя и това, че той наистина притежава съответния актив. Според Iansiti \& Lakhani (2017) блокчейн е „отворена технология, която може да записва трансакции, направени между двама потребители, по един ефективен, сигурен начин за постоянно “. И в действителност това са нейните основни качества. Блокчейн технологиите осигуряват връзка тип „потребител-къмпотребител“, използвайки протокол, за да валидира (да удостовери автентичността) новите блокове.

Друга прилика между биткойн и „Хавала” е анонимността, с която те се характеризират. Основна определяща характеристика на биткойн е децентрализираната мрежа, която няма централен орган за обработка или проверка на транзакциите, а вместо това е свързана чрез верига от мрежи на блокчейна, която проверява и потвърждава всяка транзакция. 


\section{„Хавала“ и организираната престъпност в Република България}

През м. януари 2019 г. в Република България бе разкрита мрежа от лица, участващи в използването на метода „Хавала” за прикриване на особено тежки престъпления. Това бе и първият сблъсък на практиката в лицето на правозащитните органи в Република България с това явление, поради което и към момента то продължава да се отличава с особена актуалност. Този случай създаде един особено интересен за юридическата наука прецедент и постави на преден план пред компетентните органи в Република България и особено пред Прокуратурата едно сериозно предизвикателство борбата с един новооткрит от нашата правна система (но съвсем не нововъзникнал) вид организирана престъпност. Предизвикателството е отправено и към правната теория, чиято задача е да изясни проблема и да способства за неговото институционализиране в правото, като даде ефективни и адекватни решения за неговата специфична уредба. В условията на относителна новост и анонимност на „Хавала“ в българската доктрина и практика е необходимо да се обърне по-голямо внимание на правилната квалификация на престьпленията, които са извършени чрез нейното прилагане.

Разбира се, появяването на този конкретен тип организирана престьпност в настоящия момент не е случайно, а има своето логично обяснение. Ако до момента на този въпрос не е било обръщано достатъчно внимание, то причината е, че в близкото минало същото не е имало толкова широко приложение в рамките на Европейския съюз. Това е така, тьй като, от една страна, то произхожда от други народи и общества, чието присъствие в Европа се увеличи значително през последните години, а от друга липсата на подобни традиции сред европейските нации, прави системата непривлекателна за европейските граждани. Все пак, както вече посочихме - един от основните задвижващи елементи на „Хавала“ е доверието, което обаче е изграждано в практикуващите я общества с хилядолетия, каквато хилядолетна традиция в Европа не се установява. Избухналата в Сирия гражданска война обаче доведе до засилено и двупосочно движение на маси от хора и капитали между различни региони на Азия, Африка и Европа. Съществена роля в това отношение изигра и безпрецедентният миграционен натиск към Европа, настъпил както в резултат на гражданската война в Сирия, така и от развитието други процеси, генериращи нестабилност. Безспорно е, че това движение, което често се осъществява неконтролируемо, постави на дневен ред порядките и обичаите на народностите, които участват в миграционния процес. Мащабът на този процес засили и насочи вниманието на държавните органи и институции към определени рискови групи от лица и, в крайна сметка, съществуването и използването на системата „Хавала“ за финансиране на организирана престьпност и тероризъм попадна в полезрението на компетентните институции.

Общоизвестен факт е, че към настоящия момент е внесен в съда обвинителен акт, с който Прокуратурата на Република България е поставила началото на първото наказателно преследване срещу разкрита на територията на страната престьпна група, използваща системата „Хавала“. Тук обаче е налице и една важна особеност. Както изяснихме по-горе, „Хавала“ е анонимен метод за извършване на парични преводи без реално движение на парични средства. В разкрития от Прокуратурата случай, наблюдаваме допълнително комплициран вариант, в който посредством системата „Хавала“ не просто се предоставят финансови средства на определи лица, а логистична подкрепа на терористични организации, опериращи на територията на друга държава. Така, установената от Прокуратурата мрежа от лица е организирала не просто движение на парични средства (финансиране в тесен смисъл), но и подпомагане посредством различни движими вещи, закупувани посредством системата „Хавала“. Оказва се, че 
„Хавала“ се използва не само за предаване на парични средства, но би могла да намери приложение и при закупуването на определени стоки или услуги.

В редица държави сама по себе си системата „Хавала“ не е незаконна дейност, като например в редица страни от Азия намира широко приложение в ежедневния граждански оборот. Очевидно е обаче, че като явление тази система разкрива възможност за извършването или финансирането на редица престъпления, в това число и такива, извършвани от терористични организации. Как обаче стои въпросът със системата „Хавала“, изхождайки от действащото българско законодателство?

При внимателен анализ на това явление и относимите към него правни разпоредби откриваме следните особености:

В Република България банковата дейност, както и предоставянето на платежни услуги се намира под лицензионен режим, чиято правна уредба се намира в Закона за кредитните институции, като относими в тази насока са и разпоредбите на Наредба №2 за лицензите, одобренията и разрешенията, издавани от Българската народна банка (БНБ) по Закона за кредитните институции. Така чл. 1, ал. 1 от ЗКИ гласи: „Този закон урежда условията и реда за лицензирането, осъществяването на дейността, надзора за спазването на формулираните във вторичното право на ЕС пруденциални изисквания и прекратяването на кредитните институции (банките) с цел да се осигури стабилна, надеждна и сигурна банкова система и защита интересите на вложителите, както и изискванията за оповестяване на информация от страна на Българската народна банка в областта на пруденциалното регулиране и надзор върху банките”.

Видно е, че законодателят е възприел един по-стриктен подход при регулацията на този вид дейности и е обърнал особено внимание на операциите по прехвърляне на парични средства. Същевременно системата „Хавала“ би могла да се квалифицира именно като такава операция (по превод на средства) и се явява в пряко противоречие с уредения у нас правен режим на този институт.

От гледна точка на разпоредбите на Наказателния кодекс (НК) на Република България е предвидена и наказателна отговорност за подобни деяния, като съгласно чл. 252, ал. 1 от НК: „Който без съответно разрешение извършва по занятие банкови, застрахователни или други финансови сделки, предоставя платежни услуги или издава електронни пари, за които се изисква такова разрешение, се наказва с лишаване от свобода от три до пет години и с конфискация до $1 / 2$ от имуществото на дееца." Квалифициран състав е предвиден в ал. 2, когато с дейността по ал. 1 са причинени другиму значителни вреди или са получени значителни неправомерни доходи. По този начин у нас на практика използването на системата „Хавала“ само по себе си е инкриминирано деяние, което подлежи на наказателно преследване. За да е налице проявлението на този фактически състав, следва от обективна страна едно лице да извършва и то като негово занятие (следователно изолирани случаи не могат да попадат в обхвата на цитираната разпоредба) посочените сделки и същевременно да не разполага с разрешение за това. Субективната форма на това деяние винаги е умисъл, като деецът следва да съзнава характера и естеството на извършваните от него сделки, както и обстоятелството, че не разполага със съответното разрешение или лиценз за извършването им. Като пример можем да посочим, че ако се касае за лице, което притежава лиценз за извършване на посочените правни действия, но той е бил отменен, за да е налице от субективна страна деянието по чл. 252 от НК, следва фактьт на отмяната да е достигнал знанието на дееца.

На следващо място, изхождайки от специфичния характер на системата „Хавала““, в частност обстоятелството, че сумите се предават винаги в брой, то същата влиза в пряко противоречие с действащия у нас Закон за ограничаване на плащанията в брой 
(ЗОПБ). Съгласно чл. 3, ал. 1 от цитирания нормативен акт плащанията на територията на страната се извършват само чрез превод или внасяне по платежна сметка, когато са:

1. На стойност, равна на или надвишаваща 10000 лв.;

2. На стойност под 10000 лв., представляваща част от парична престация по договор, чиято стойност е равна на или надвишава 10000 лв.

Цитираната разпоредба (по силата на ал. 2) е приложима и в случаите на плащания в чуждестранна валута, когато левовата им равностойност е равна на или надвишава 10000 лв. От своя страна, равностойността в български левове се определя по курса на Българската народна банка в деня на плащането.

С оглед изложеното следва, че системата „Хавала“ нарушава и други законови разпоредби, извън уредбата на Наказателния кодекс (в случаите, когато плащането е на стойност над 10 000,00 лв.).

За това деяние е предвидена административно-наказателна отговорност в чл. 5, ал. 1 от ЗОПБ, който предвижда санкция в размер на 25 на сто от общия размер на направеното плащане, ако същото е извършено от физическо и 50 на сто - ако е извършено от юридическо лице. Разбира се, наказателната отговорност би довела до изключване на административната за дееца, но тук следва да се има предвид, че санкцията по чл. 5, ал. 1 от ЗОПБ се налага не само на прекия извършител на деянието, но и на всяко лице, което е допуснало извършването на такова деяние. По този начин би могла да се ангажира отговорността на всички участници в конкретния превод, независимо дали същите могат да бъдат подведени под наказателна отговорност.

Вредното въздействие на системата „Хавала“ отива дори по-далеч от заобикалянето и нарушаването на наказателното законодателство и на разпоредбите, уреждащи начините на плащане между гражданите в Република България. Направеният анализ дава основание за опасения и по отношение на множество други правни отрасли и правовия ред в страна като цяло. Очевидно е на пьрво място, че „Хавала“ оперира като една анонимна банкова система с мащаб, способен да конкурира дейността на самите тьрговски банки. Същевременно системата „Хавала“ работи и осъществява тази своя дейност без да зачита и да спазва каквито и да било държавни регулации. Така тази дейност, за разлика от банковата, се осъществява, без пред нея да се поставя въпроса за необходимостта от лицензиране. В тази насока законодателят е обърнал особено внимание на банковата дейност, като е предвидил специален разрешителен режим за нейното осъществяване, предмет на правна регламентация на Глава трета „Лицензиране и разрешения" от Закона за кредитните институции. В посочения нормативен акт с основание лицензирането е уредено като една строго формална и значително усложнена процедура, която има за цел да се увери, че съответната кредитна институция изпълнява множеството законови изисквания и предстоящата й дейност ще съответства на нормативната уредба. Този извод е очевиден от разпоредбата на чл. 13, ал. 2 от ЗКИ, която подробно урежда конкретните документи, които следва да бъдат приложени в заявлението за издаване на лиценз за банкова дейност.

Силно впечатление в тази насока прави и чл. 13, ал. 2, т. 3 от ЗКИ, който изисква към заявлението да се приложи план за деловата дейност на банката, съдържащ изчерпателно описание на дейностите, които ще бъдат извършвани; клиентската и продуктовата структура; целите, политиката и стратегията на банката; финансова прогноза за развитие за тригодишен период.

Точка 4 от цитираната разпоредба пък изисква предоставянето на описание на управленската и организационната структура, включващо дейността на отделните организационни единици; разпределението на отговорностите между изпълнителните директори и другите администратори; организацията и управлението на 
информационната система на банката, включително на механизма за защита на информацията.

Видно е, че законодателят желае да получи една особено подробна информация за субекта, който ще осъществява банкова дейност, и едва тогава е предвидил, че такава дейност може да се упражнява на територията на Република България.

С това обаче проблемът далеч не се изчерпва - освен, че изцяло избягва лицензионния режим на банковото законодателство, уреден в Закона за кредитните институции, „Хавала“ функционира, избягвайки изключително сериозния контрол, който държавата осъществява спрямо банковите институции. По този начин се избягва високата степен на прозрачност на банковите операции и значително се затруднява осъществяването на този контрол. В тази насока е и Решение №11087 от 09.08.2011 г. на $\mathrm{BAC}$, в което се изтьква именно тази проследимост на банковите преводи като посочва, че доказателственото средство за установяване на обстоятелството на извършени плащания от банкова сметка са писмените доказателства-извлечения за движението на сметката на хартиен носител, като с помощта на вещо лице тези документи биха могли да се анализират. Така, съдът обрьща внимание на възможността да бъде проследено всяко движение на дадена банкова сметка. Нещо повече - банките, от една страна, се лицензират, но и след получаването на лиценз законът поставя към тях редица изисквания и конкретни правила за осъществяването на самата им дейност. Така например ЗКИ въвежда изрични изисквания към собствения капитал на банките (чл. 3947 от ЗКИ), правила за разкриване на конфликтите на интереси (чл. 51-54 ЗКИ), правни норми, уреждащи детайлно банковата и професионалната тайна (чл.62-67 ЗКИ) и редица други такива изисквания. При тяхното несъблюдаване е налице възможност за отнемане на лиценза на съответната банкова институция, като по този начин държавата разполага с ефективен механизъм да обезпечи законосъобразното функциониране на банковата дейност у нас, както и средства за преустановяване на незаконосъобразната банкова дейност, който режимът на системата „Хавала“ изцяло заобикаля.

На следващо място, доколкото системата „Хавала“ по правило работи с валути от различен тип, като често конвертира същите в местна валута, то тук наблюдаваме и заобикаляне на валутното законодателство на страната ни, чийто основен източник е Валутният закон (В3). Негов предмет, видно от разпоредбата на чл. 1, е уреждането на сделките и плащанията между местни и чуждестранни лица; презграничните преводи и плащания; сделките с чуждестранна валута по занятие; сделките с благородни метали и скъпоценни камъни и изделия с и от тях по занятие; тяхното пренасяне през границата на страната и преработката им; пренасянето на парични средства презграницата на страната; събирането, поддържането и предоставянето на статистическа информация за платежния баланс и международнатаинвестиционна позиция на страната, както и упражняването на валутен контрол.

Видно е, че почти всички хипотези на чл. 1 от В3 всъщност са обхванати от дейността на системата „Хавала“. И всички те се осъществяват, без да се държи сметка за правилата на валутното и финансовото ни законодателство. Валутният закон съдържа конкретни правила за обмяната на валута в чл. 3, като поставя изискването сделките с валута да се извършват само от лице, което е регистрирано по Търговския закон; както и лице, регистрирано като търговец по законодателството на държава - членка на Европейския съюз, или на друга държава - страна по споразумението за Европейското икономическо пространство, което е вписано в публичния регистьр на лицата, извършващи дейност като обменно бюро. Ал. 3 на цитираната разпоредба предвижда, че в Министерството на финансите се води и поддържа публичен регистьр на лицата, извършващи дейност като обменно бюро, като за вписването в него се събира такса в 
полза на държавата. Извършването на презгранични преводи и плащания пък е уредено в чл. 6 от В3, който изрично изисква при извършването на този тип дейност да се посочва основанието за превода, с оглед възможността за неговата проследимост и прозрачност. Отделно от това, ал. 2 поставя изискването лице, което извършва презграничен превод или плащане към трета страна в размер на 30000 лв. или повече или тяхната равностойност в друга валута, да представи на доставчиците на платежни услуги сведения и документи, касаещи произхода на тези средства, тяхното предназначение и други данни, определени в съвместна наредба на БНБ и Министьра на финансите.

Законодателят е предвидил и конкретни условия за пренасянето на парични средства през границата на страната в чл. 11 от В3, който урежда правото на физическите лица да пренасят през границата на страната неограничено количество парични средства, но при определен режим на деклариране, уреден в чл. 11а от В3. Цитираната разпоредба допуска пренасяне на парични средства през границата на страната за или от трета страна, но когато се касае за средства в размер на 10000 евро или повече или тяхната равностойност в левове или друга валута за или от трета страна, това пренасяне подлежи на деклариране пред митническите органи. Отделно от това, при пренасяне на парични средства в размер на 30000 лв. или повече или тяхната равностойност в друга валута през границата на страната за трета страна, митническите органи изискват по служебен път информация за наличие или липса на задължения по чл. 87 от Данъчноосигурителен процесуален кодекс (ДОПК).

В своята практика Върховният касационен съд (ВКС) е имал повод да се произнесе, като изясни съдържанието на чл. 11а от В3, приемайки, че предмет на деклариране е цялата сума, а не само тази част, надхвърляща разрешения размер от 10 хиляди евро. В Решение № 86 от 07.03.2014 г. по нак. д. № 94/2014 г. на Върховния касационен съд се посочва, че в тази връзка Валутният закон е категоричен и ако декларираната информация за пренасяната валута е невярна или непълна, задължението за деклариране се смята за неизпълнено. Тези изисквания се прилагат и когато се касае за дарени суми - в този смисъл е Решение № 7330 от 23.05.2012 г. по адм. д. № 3942/2011 на Върховния административен съд. Тук следва да се отбележи, че този режим на деклариране не нарушава общностното право и не ограничава свободата на движение на капитали, (която е една от четирите основни свободи в рамките на ЕС), тъй като не са налице разпоредби, ограничаващи движението на капитали, а единствено изискване това движение да бъде декларирано ${ }^{3}$.

В разпоредбите на чл. 8 и 10 от В3 са предвидени правомощия на БНБ за изискване на определена информация от лицата, осъществяващи тази дейност, чл. 10a от В3 обсъжда създаване на митнически регистри и редица други механизми, които в крайна сметка „Хавала“ заобикаля. Всички тези правила целят постигането на толкова ценната за всяка една правова държава прозрачност при движението на финансови активи и възможност за контрол върху тези важни за всяко общество операции, от което по недвусмислен начин следва, че и от гледна точка на финансовото и валутното ни законодателство системата „Хавала“ е общественоопасно явление.

Горепосоченият анализ поставя и въпроси от данъчноправна гледна точка. От една страна, предвид естеството на системата „Хавала“, е видно, че се осъществява финансова дейност, включваща в себе си банкова дейност и други банкоподобни и дори валутни операции. От друга страна, вън от всякакво съмнение е, че тази дейност генерира огромни по размер приходи, които остават скрити за държавните органи. Нещо повече, целта на системата „Хавала“ е именно постигането на този ефект. По правило

\footnotetext{
${ }^{3}$ Този въпрос е подробно изяснен в Решение № 414 от 12.10.2010 г. по н.д. № 378/2010 г. на Върховен касационен съд, Решение № 186 от 21.04.2009 г. по н.д. № 159/2009 г. на Върховен касационен съд.
} 
обаче, доходите на физическите лица и търговците в Република България подлежат на данъчно облагане, като за целта действат редица нормативни актове, уреждащи тази материя - Закон за данъците върху доходите на физическите лица, Закон за корпоративното подоходно облагане, Закон за данък добавена стойност и др. Целта на това законодателство е, в крайна сметка, да се гарантира приносът на всеки участник в тьрговския или гражданския оборот към обществото. Данъчното законодателство е публичноправна материя, която по детайлен начин урежда тези процеси, но необходимо условие, за да функционира, е наличието на механизъм за установяване и прозрачност при осъществяване на дейността, която подлежи на данъчно облагане. Очевидно е, че такъв механизъм не може да се приложи за явление, което по дефиниция действа извън законовите рамки.

Видно е, че нормативната уредба в Република България е предвидила редица способи и механизми за контрол на тази специфична дейност, но всички тези правни институти се оказват трудно приложими в борбата срещу системата „Хавала“, тьй като същата оперира, извън техния обхват по „скрит“ и „законспириран” начин.

\section{Заключение}

В резултат на направения анализ, би могъл да бъде направен изводът, че в световен мащаб системата „Хавала“ е средство за анонимен и трудно проследим превод на парични средства и това нейно качество я характеризира като явление с висока степен на обществена опасност за всяка правова държава, независимо дали същата е забранила тази дейност сама по себе си или не. На практика, системата „Хавала“ позволява почти непроследимо и анонимно прехвърляне на парични суми, които заобикалят изцяло банковите институции и регулиращите ги държавни органи, а наред с това и нормите от данъчноправен характер.

От гледна точка на националното законодателство в Република България са налице мерки, които да противодействат срещу създаването на подобна „извънбанкова мрежа" за превод на средства. Следователно законодателната уредба е необходимо да се усъвършенства, за да не изостава от обективната действителност и да осигурява ясни правни механизми за противодействие на този неконвенционален тип престьпност, съчетаващ и редица обичаи и културни особености. С оглед непрестанното развитие на обществените отношения и актуалността на проблема с прането на пари и финансирането на престъпни и терористични организации, националните правораздавателни органи ще се сбльскват с все по-големи предизвикателства в тази насока, като трудностите в практиката биха могли да продиктуват и необходимостта от нови действия на законодателя. С голяма степен на вероятност може да се твърди, че съществуват и други подобни системи за заобикаляне законодателството в Република България, които оперират по сходен начин. Очевидно, е че са налице известни недостатъци както в международното публично право, така и пред националното наказателно право за разкриване и противодействие на този тип престьпност. В този смисъл още веднъж е необходимо да се развива уредбата за международноправно взаимодействие по отношение на прането на пари, а също и националното законодателство, което, от една страна, трябва да инкорпорира международното право в българската правна система, а на следващо място да изработи по-ефективни модели за сътрудничество между органите на съдебната власт и правоохранителните органи. Единствено по този начин би могло да се постигне ефективно противодействие на системата „Хавала“ и други подобни методи, използвани от организираната престьпност. 


\section{Библиография}

Adeso. (2012). Guidelines: How to use Hawala in Somalia. Prepared by Adeso on behalf of the Somalia Cash Based Response Working Group (CBRWG). Retrieved from https://www.calpnetwork.org/wp-content/uploads/2020/01/Adeso-Guidelines-onHawala-May-2012_Final.pdf

Aldimirov, N. (2017). Avtoreferat kam disertatsiya na tema „Model za preventsiya na izpiraneto na pari v targovskite banki”. Izdatelski kompleks - UNSS.[Алдимиров, Н. (2017). Автореферат къмдисертаџияна тема „Модел за превенџия на изпирането на пари в търговските банки". Издателски комплексУHCC].Retrieved from http://konkursi.unwe.bg/documents/571Avtoreferat\%20Aldimirov.pdf

Aldimirov, N. (2017). Protsesat na izpirane na pari i preventsiyata mu v targovskite banki. SofiyaIzdatelskikompleks - UNSS [Алдимиров, Н. (2017). Прочесът на изииране на пари и превенциятаму в търговските банки. София. Издателски комплексYHCC].

Alsubaie, S. (2017). Hawala vs. Bitcoin: The digital trust network of the 21 st century. Medium. Retrieved from https://medium.com/@saad_alsub3y/hawala-vs-bitcoin-thedigital-trust-network-of-the-21st-century-e5f3555b9fa6

Chene, M. (2008). Hawala remittance system and money laundering. U4 Expert Answer. Anti-Corruption Resource Centre, Norway. Retrieved from https://www.u4.no/publications/hawala-remittance-system-and-money-laundering.pdf

Credit Institutions Act. (2006). Retrieved from http://www.minfin.bg/upload/39102/Credit_Institutions_Act.pdf. [Закон за кредитните институции]. Retrieved from https://www.lex.bg/laws/ldoc/2135532723

Currency Act. (1999). [Валутен закон. (1999)]. Retrieved from https://www.lex.bg/en/laws/ldoc/-12802047

Decision №7330 of the Supreme Administrative Court under adm. case. № 3942/2011. [Решение № 7330 от 23.05.2012 г. на ВАС по адм. д. № 3942/2011]. Retrieved from http://www.sac.government.bg/court22.nsf/d6397429a99ee2afc225661e00383a86/01 008d5e6dc80b9bc2257a06003a28bc?OpenDocument

Decision №11087 of the Supreme Administrative Court under adm. case. № 116/2011. [Решение №11087 на ВАС по адм. д. № 116/2011]. Retrieved from http://www.sac.government.bg/court22A.nsf/d6397429a99ee2afc225661e00383a86/c 22583660052f5ecc22578da0061c196?OpenDocument

Decision № 86 of the Supreme Court of Cassation under crim. c. № 3942/2011. [Решение № 86 от 07.03.2014 г. по нак. д. № 94/2014 г. на ВКС]. Retrieved from http://www.vks.bg/pregled-akt?type $=$ otspisak\&id=22687BD51DDC4F1DC2257C94004AF5AB

Decision № 186 of the Supreme Court of Cassation under crim. case. № 159/2009. [Решение № 186 от 21.04.2009 г. по н.д. № 159/2009 г. на Върховен касационен съд]. Retrieved from http://www.vks.bg/pregled-akt?type $=$ otspisak\&id=DD30372AEED96969C22577930053BA86 
Decision № 414 of the Supreme Court of Cassation under crim. case. № 378/2010. [Решение № 414 от 12.10.2010 г. по н.д. № 378/2010 г. на Върховен касационен съд]. Retrieved from http://www.vks.bg/pregled-akt?type=otspisak\&id=1ABE6FAC2FFE5843C22577D0002E2B28

El-Qorchi, M. (2002). The Hawala System. Finance and Development, 39 (4). Retrieved from https://www.imf.org/external/pubs/ft/fandd/2002/12/elqorchi.htm

European Parliament, Special Committee on organised crime, corruption and money laundering. (2013). Working document on money laundering. [Европейски Парламент, Специална комисия по организираната престьпност, корупцията и изпирането на пари. (2013). Работен документ относно изпирането на napu.(DT\925991BG.doc)]. Retrieved from https://www.europarl.europa.eu/meetdocs/2009_2014/documents/crim/dt/925/925991 1925991bg.pdf

FATF. (2013). The role of Hawala and other similar service providers in money laundering and terrorist financing. Paris. Retrieved from https://www.fatfgafi.org/documents/documents/role-hawalas-in-ml-tf.html

General Assembly Resolution. (2000). United Nations Convention against Transnational Organized Crime, (55/25 of 15 November 2000). [Конвенция на Организацията на обединените нации срещу транснационалната организирана престьпност].Retrieved from https://www.unodc.org/documents/treaties/UNTOC/Publications/TOC\%20Conventio n/TOCebook-e.pdf

Iansiti, M.\& Lakhani, K. (2017). The Truth About Blockchain. Harvard Business Review. Retrieved from https://hbr.org/2017/01/the-truth-about-blockchain

Pathak, R. (2003). The obstacles to regulating the Hawala: A cultural norm or a terrorist hotbed. Fordham Int'l LJ, 27, 2007. Retrieved from https://heinonline.org/HOL/LandingPage?handle=hein.journals/frdint27\&div=62\&id= \&page

King, L. W. (2005). The code of Hammurabi: Translated by LW King. Yale University. Retrieved from https://avalon.law.yale.edu/ancient/hamframe.asp

Law on Measures against Money Laundering. (2018). [Закон за мерките срещу изпирането на пари. (2018)]. Retrieved from https://www.lex.bg/bg/laws/ldoc/2137182924

Limitation of Cash Payments Act. (2011). [Закон за ограничаване на плащанията в брой.]. Retrieved from https://www.lex.bg/laws/ldoc/2135718725

Pushkarova, I. (2014) Izpirane na pari. Razgranichenie ot blizki do nego prestaplenia. Teza, 8, str. 2. [Пушкарова, И. (2014) Изпиране на пари. Разграничение от близки до него престьпления. Теза, 8, стр. 2]. Retrieved from http://justicedevelopment.org

Ordinance No 2 of the BNB of 22 December 2006 on the Licenses, Approvals and Permissions Grantedby the Bulgarian National Bank According to the Law on Credit Institutions. [Наредба № 2 на БНБ за лицензите, одобренията и разрешенията, издавани от Българската народна банка по Закона за кредитните институции]. 
Retrieved from

http://bnb.bg/bnbweb/groups/public/documents/bnb_law/regulations_licenses_bg.pdf

Strahilova, E. (2019). SistemataHauala i traynoto i navlizane v Bulgaria i Evropa. Balgarska Nauka. [Страхилова, Е. (2019). СистематаХауала и трайното й навлизане в България и Европа. Българска Наука.] Retrieved fromhttps://nauka.bg/sistematahauala-trainoto-navlizane-balgariya-evropa/.

Tax and Social Insurance Procedure Code. (2006). [Данъчно-осигурителен процесуален кодекс. (2006)]. Retrieved from https://www.lex.bg/laws/ldoc/2135514513 


\title{
CONSTITUTIONAL AND FINANCIAL LEGAL ASPECTS OF THE STATE BUDGET IN THE REPUBLIC OF BULGARIA
}

\author{
VALENTINA GOLEVA ${ }^{1}$ \\ VESELA MIRCHEVA ${ }^{2}$
}

\begin{abstract}
The study examines the role and place of the two major political institutions, namely government and parliament, in the preparation and adoption of the state budget. The importance of the state budget for the implementation of the political program for the management of the government, as well as the need for its public discussion in the parliament, is substantiated. That is why the annual state budget is adopted in the legal form of the law and the legislative procedure for its adoption is followed, focusing on its specifics. An analysis is presented of the position of the state budget in the budget system of the Republic of Bulgaria, and in particular - in the consolidated fiscal system. The legal regulation of the budgetary process is also examined, and its stages are monitored.
\end{abstract}

Keywords: government, parliament, legislative procedure, state budget, budget system, budget process

JEL Codes: K10, H61

\section{Introduction}

The state budget plays a key role in its governance. It is the financial instrument through which the implementation of state policy is ensured. Moreover, the very existence of the state is inconceivable without the legal regulation of the institute of state budget. It provides for the maintenance of state institutions, it is so necessary for their normal functioning, as well as the foundations of economic management. However, state finances should be in a certain balance in their revenue and expenditure parts. In this regard, the state budget should be planned in accordance with the basic budget principles such as unity, completeness, publicity, balance, community of use, specialization, timely elaboration, accuracy in calculations, age, clarity and economy (Stoyanov, 1938). Serving as a material basis of the institutional and functional structure of state, the state budget ensures the realization of so-called "Common good“" (Bliznashki, 2007, p. 76). In other words, it contributes to the establishment and preservation of the value consensus that forms the core of any society. In this sense, the state budget has not only financial and economic, but also social, legal and political significance. The saying of English historian Hallam is well-known that in England public freedoms were not won with blood, they were bought with money (Kostov, 1976).

\footnotetext{
${ }^{1}$ Assoc. Prof., PhD "Law and History Faculty”, South-West University “Neofit Rilski”, Blagoevgrad, Bulgaria, aleksandrovavalentina@abv.bg

ORCID iD https://orcid.org/0000-0002-3819-3616

${ }^{2}$ Chief Assist. Prof., PhD “Law and History Faculty”, South-West University “Neofit Rilski”, Blagoevgrad, Bulgaria, valensia@abv.bg ORCID iD https://orcid.org/0000-0002-6184-7788
}

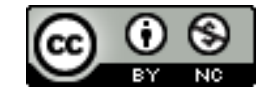

This work is licensed under a Creative Commons Attribution-NonCommercial 4.0 International License. 


\section{Methodology}

The systematic, comparative-legal and historical-legal method was used in the research. The systematic method reveals the relationship between the analyzed constitutional and financial law institutes such as government, parliament, budget system, consolidated fiscal system, state budget, etc., which are relevant to the subject of the current study. The comparative legal method presents the good practices in foreign countries and the achievements in various foreign legislations in the legal framework of the institute of the state budget and through the historical-legal method, the historical development of the legal regulation in the Republic of Bulgaria of the adoption of state budget, its subject scope, structure and term of action is traced.

\section{Constitutional bases of the state budget as a governance tool}

In modern parliamentary governance, the role of government has a key role for the functioning of the political system in the country. This is determined by the historical development of parliamentarism from classical to rationalized parliamentarism after the Second World War. According to the traditional meaning of the principle of separation of powers, developed in its classical form by Montesquieu, on the basis of which the modern state is built in the New Age, the Council of Ministers is the holder of executive power.

In this sense, it plays the role of an executive body, implementing the operational governance of the country. This characteristic is constitutionally regulated in the Constitution of the People's Republic of Bulgaria (Article 38, 1947) and the Constitution of the People's Republic of Bulgaria (Article 98, 1971). However, the modern reading of this principle imposes on the traditional division of state power into legislative, executive and judicial (Article 8 of the Constitution of the Republic of Bulgaria, 1991) a new understanding of the principle of separation of powers. Exactly ,policy-making”, ,policy implementation” and ,policy control” (Bliznashki, 2007, p. 72; Loewenstein, 1965, pp. 45-52). The dynamics of social processes predetermine the gradual shift of the political center of political decision-making from the parliament to the government. In practice, it turns out that from governing through legislation in classical parliamentarism to ,governing of the government through parliament" in rationalized parliamentarism (Bradshaw \& Pring, 1981, p. 9).

This kind of transformation in the structure of the modern political process is regulated in the text of Art. 105, para. 1 of the Constitution (1991), according to which the Council of Ministers governs and implements the domestic and foreign policy of the country. This provision is of key importance for the functional characteristics of the government, outlining two different levels in its activity, and hence both its main functions. In the systematic interpretation of Art. 105, para. 1 in connection with Art. 62, para. 1, second sentence of the Constitution (1991), the conclusion is imposed that the management and implementation of the country's policy are a function of the Council of Ministers, while the control over this policy is a function of the parliament in accordance with the new tripartite division of power. The National Assembly realizes its control function through the means of parliamentary control, characteristic of the parliamentary form of government - questions, inquiries (interrogations), inquiries (interpellations), vote of no confidence, surveys and polls (Art. 79, para. 3; Art. 8990 of the Constitution, 1991). In this way, the parliament engages the political responsibility of the government for the policy pursued by it, on the one hand, and on the other hand - for the compliance of the implemented policy with the political goals set by the government, which it should achieve with its governance.

The function of political leadership of the government is realized through the preparation of its political program. In it, it outlines the political goals of its governance, as well as the means for achievement of them. In this way, it takes the political initiative for the 
governance of the country and therefore bears the corresponding political responsibility before the parliament - how necessary and appropriate are the actions, taken by it (Bliznashki, 2009). It is logical for this program to be presented in the election of the government itself, although there is no explicit constitutional requirement in this regard. This „omission“ in the Constitution of 1991 has its basis in the political situation in the years immediately following the 1989 transition from totalitarian to democratic governance and from a planned to a market economy. The constitutional legislator suggested that profound structural changes in the sociopolitical and socio-economic life of the country could lead to frequent changes of governments and the need for the rapid formation of a government on a coalition basis. Precisely in order not to complicate this process, the current Constitution does not contain a positive constitutional provision in this direction. In parliamentary practice, there is a tendency for the Council of Ministers to present its government program to the National Assembly afterwards after its election. Thus, in practice, the parliament chooses the government not because of the policy it will pursue, but because of its staff. Art. 99 of the Constitution (1991) regulates the formation of the parliamentary government on the principle of collective investiture, in which the National Assembly elects both the Prime Minister and the composition of the future cabinet, voting it ,en bloc”, i.e. as a team. A number of modern constitutions regulate the requirement to present the political program of the future government by the candidate for Prime Minister in his election, such as the Constitution of the Kingdom of Spain of 1978 (Article 99, paragraph 2), and the Portuguese Constitution of 1976 - the content of the government program is even legally defined (Art. 188, and in the new edition of 1989 - Art. 191) (Bliznashki, 2009). In a case of a constitutional revision, it would be appropriate to include in the procedure for forming the government the presentation of its governing program.

Parliament must vote on the government's program in Hungary, Belarus, Ukraine, Kazakhstan, Lithuania, Estonia, the Czech Republic, Slovakia, Turkey, Poland, Romania, Croatia and Finland. Such an obligation is not constitutionally enshrined in Bulgaria, as well as in Russia, Ireland, Latvia, Slovenia, Belgium, Sweden and in Denmark, however, it has become a political practice (Tanchev \& Belov, 2009).

The government's political program is translated into laws through the exercise of the right of legislative initiative. Parliamentary practice shows that the active submitter of bills is precisely the government, although every Member of Parliament is an authorized subject in this direction (Article 87, paragraph 1 of the Constitution, 1991). The constitutional law states that ,governments submit to parliaments more than $70 \%$ of bills, and more than $90 \%$ of adopted legislative acts are those proposed by governments" (Pactet, 1992, p. 423; Baglay, Leibo \& Entin, 2010, p. 572). In this regard, „Indicative are the statistical data on the legislative activity of the XLI National Assembly for the period from 14 July 2009 to 14 March 2013: with a total number of submitted bills 985 - 515 were submitted by the Council of Ministers, and 562 laws were adopted, and 428 laws from them were initiated by the government." (Bliznashki, 2015, p. 329). Thus, in fact, the government „dictates” the legislative program of the parliament, which adopts the laws necessary for the government itself to conduct one or another policy, and hence - to achieve the pre-set political goals. The government is a major initiator of bills in a number of other countries - Britain, France, Belgium, the Netherlands, Sweden, Greece, Turkey, Austria, Germany, Spain, Portugal, Italy, Serbia, Albania, Lithuania, Latvia, Estonia, Poland and others. In France the government exercises this power through the prime minister, and in Iceland individual ministers have the right of legislative initiative, not the government as a collective body (Tanchev \& Belov, 2009).

With the support of the parliamentary majority, which actually elected this government, the bills introduced by the Council of Ministers are adopted as laws. They are applied by the government, which acts on the basis of and in implementation of the laws (Article 114 of the 
Constitution, 1991). In other words, the political initiative starts with the government, defined in its political program. In the form of bills, it passes through the National Assembly, which legally „dresses“ it as a law, and returns to the government for the implementation of the law. This is the basis of the other function of the government - the function of implementing the domestic and foreign policy of the country. Through the manifestation of this function the Council of Ministers ensures public order and national security, carries out the general management of the state administration and the Armed Forces, manages the implementation of the state budget, organizes the management of state property, concludes, approves and denounces international treaties (Article 105, paragraph 2 in connection with Article 106 of the Constitution, 1991).

However, in order to implement its political program, the government should also provide with the necessary financial resources. That is why its exclusive prerogative is the preparation and submission to the parliament of the draft law on the state budget (Article 87, paragraph 2 of the Constitution, 1991). Carrying out the operational governance of the country, the Council of Ministers is aware of which social spheres generate revenues, respective expenditure and how these two sides of the budget should be balanced so that it secures its finances for achieving its political objectives. In the comparative legal aspect, the government is authorized to prepare and submit the bill for the state budget all over the world (Tanchev \& Belov, 2009).

\section{Parliamentary legislative process in the adoption of law on the state budget}

The Law on the State Budget for the relevant year (which is different for each year) shall be adopted in accordance with the provisions of the Constitution and the provisions of Art. 76-86 of the Rules of Organization and Procedure of the National Assembly (2017) legislative procedure with certain specifics (Decision of the Constitutional Court № 7/2005, promulgated SG, issue 52/2005), following the classical phases of the parliamentary legislative process. These legislative phases are exercising the right of legislative initiative, discussion of the bill (preliminary discussion in the standing parliamentary committees, plenary discussion at first reading, additional discussion in the standing committee and plenary discussion at second reading), voting on the bill and promulgation of the already adopted law (Bliznashki, 2015). The draft law on the state budget with the motives to it (according to §1a of the Additional provisions of the Law on the Normative Acts (1973), no preliminary assessment of the impact of this bill is required, shall be submitted by the Council of Ministers to the Chairman of the National Assembly on paper and in electronic form, by registering in the public register „Bills“. According to Art. 79, para. 4 of the Public Finance Act (PFA, 2013) it shall be submitted by October 31 of the respective year so that the Parliament should have sufficient time to discuss and adopt it. In the motives, the submitter gives an opinion on the expected consequences, including financial, of the application of the bill. The Chairman of the National Assembly always appoints the Committee on Budget and Finance as the main standing committee, and always distributes the bill to all standing committees, which discuss it not earlier than 24 hours after its receipt by the members of the relevant committee. They shall submit to the Chairman of the National Assembly a motivated report within the time limits in accordance with the legislative program and the adopted one-week or two-week program for the work of the Parliament. The report of the leading committee on the draft state budget bill shall be submitted to the plenary of the parliament for the first vote no later than two months after its submission, and together with the opinions submitted on the bill (citizens and legal entities may also submit written opinions), published on the website of the leading committee on the official website of the National Assembly. This report contains a summary of the opinions received and a summary opinion of the committee itself. When the Committee on 
Budget and Finance summarizes the opinions of the standing parliamentary committees, respective the proposals of the Members of Parliament, made between the two votes of the draft law, it shall rule on them, preserving the budget balance proposed by the Council of Ministers (i.e. the ratio between revenues and expenditures) in the draft law on the state budget (Art. 79, para. 9 and Article 83, paragraph 5, item 1 of the Rules of Organization and Procedure of the NA, 2017 in connection with Article 85, paragraph 2 of the PFA, 2013).

The draft law on the state budget, the motives for it and the report of the leading committee shall be made available to the Members of Parliament not later than 24 hours before the beginning of the sitting in which the draft law will be considered. This term is analogous when considering it in a second vote, unless the National Assembly decides otherwise.

The bill is adopted in two votes, which are held in two separate sittings. At the first vote, the bill is considered after the National Assembly has heard the report of the Committee on Budget and Finance as a leading committee, the opinion of the submitter within 10 minutes and the reports of the other standing committees, if there have been any. The reports and opinions of the other committees may also be summarized.

The text of Art. 86, para. 1 of the PFA (2013) stipulates that when considering the draft law on the state budget the parliament also hears a report of the Minister of Finance on the state budget, the Chairman of the National Assembly on the budget of the National Assembly, a representative, appointed by the Supreme Judicial Council, on the budget of the judiciary authorities, reports of ministers, responsible for policy in the relevant sector. In the first vote, the bill is discussed in principle and in its entirety, as MPs pronounce on its basic provisions. A bill that is rejected in the first vote may be submitted and re-discussed only after significant amendments in its main provisions, which are reflected in the motives, and not earlier than three months after its rejection.

MPs may make written reasoned proposals for amendments to the bill, adopted at the first vote within 7 days of its adoption, respectively from its submission to MPs. The proposals are addressed through the Chairman of the National Assembly to the Chairman of the Committee on Budget and Finance, and are entered in a public register of the Parliament. Exceptionally, the National Assembly may decide to extend this term by a maximum of three weeks or to reduce it, but not by less than three days. The draft report for the second reading shall be published on the website of the leading committee on the website of the National Assembly within one day after the expiration of the above-mentioned 7-day period. On the proposals, submitted by MPs, the chairman of the leading committee may request an opinion from the Council of Ministers or from the relevant minister.

Parliament debated and voted on the bill in a second reading chapter by chapter, title by title or paragraph by paragraph. When no written proposals or objections have been made, the texts shall not be read in plenary. In this case, the texts shall be attached to the stenographic record as part of it. During the second voting, only proposals of Members of Parliament, submitted under the provisions of Art. 83 of the Rules of Organization and Procedure of the NA (2017), as well as proposals of the leading commission, included in its report (editorial corrections are also admissible). Proposals that contradict the principles and scope of the bill passed at the first reading are not discussed and voted on. An MP may substantiate the proposals, made by him, within 5 minutes for each of them. The voting is carried out by the order of art. 69 of the Rules of Organization and Procedure of the National Assembly (2017), as during the voting speeches and new proposals are not allowed. Only the proposals of MPs received under Art. 83 of the Rules of Organization and Procedure of the National Assembly (2017), the proposals of the leading commission, the editorial corrections made during the discussion, as well as proposals for rejection or postponement of a text. 
The submitter of the bill may withdraw it until the beginning of the first vote, and then - only by a Fdecision of the National Assembly. The draft law on the state budget is adopted by a simple majority, i.e. more than one-half of the present Members, when more than half of its Members are present /there is a presence of a quorum/ (Article 81, paragraphs 1-2 of the Constitution, 1991). The adopted act on the state budget for the relevant year is signed by the Chairman of the National Assembly and sent to the President of the Republic, who has two legal options. On the one hand, within 15 days of its adoption, it may sign a decree for its promulgation in the State Gazette (Article 88, paragraph 3 of the Constitution, 1991). On the other hand, within this 15-day period he may reasonably return it to the National Assembly for a new discussion (Article 101, paragraph 1 of the Constitution, 1991). The Chairman of the National Assembly shall announce at the first plenary sitting the receipt of a presidential decree under Art. 101 of the Constitution (1991). Within three days of registering, the Chairman of the Parliament instructs the leading committee to report to the MPs on the President's decree and the motives for it. The returned for new discussion act is included in the agenda of the parliament within 15 days from the receipt of the decree. The National Assembly re-adopts the act by a majority of more than half of all MPs, i.e. by an absolute majority. If the returned law does not receive the required majority and is challenged in principle, it is subject to consideration in the manner prescribed for discussion and adoption of bills. And if the returned law does not receive the required majority and only separate texts are disputed, the procedure for second vote of bills under Art. 84 of Rules of Organization and Procedure of the National Assembly (2017), there shall be voting only on the disputed and related texts. Upon the readoption of the law by the National Assembly, the President is obliged to promulgate it in the State Gazette (SG) within 7 days.

\section{Legal nature of the law on the state budget}

In the constitutional law literature (Maurer, 2007; Stoyanov, 1938; Bliznashki, 2015; Drumeva, 2018) and the Bulgarian constitutional jurisprudence the understanding prevails that the law on the state budget for the relevant year does not constitute a law in the material sense, as ,,it does not contain legal norms, regulating public relations (within the meaning of the Law on Normative Acts)". By its nature, the annual state budget is a financial plan-account of pledged revenues and projected expenditures of the state in view of the financial provision of the government's program for the relevant budget year. However, it is a law in the formal sense. The Constitutional Court accepts that the Annual Budget Laws are laws in the formal sense only because they are voted by the National Assembly under the name „law“. Basically, their real content does not contain legal norms. In their expenditure part, they contain provisions authorizing the state bodies to make the necessary expenditures of state funds up to a certain amount. The texts of the annual budget laws are acts by which the funds from the national monetary fund are managed. They are administrative acts, which, without changing their main legal characteristics (on the plan-account of pledged revenues and estimated expenditures, our note) are issued in the form of legislative acts of the National Assembly and in the prescribed for the legislative body procedure.” (Decision of the Constitutional Court № 17/1995, promulgated SG, issue 93/1995; Decision of the Constitutional Court № 8/2012, promulgated SG, issue 53/2012, Decision of the Constitutional Court № 7/2005, promulgated SG, issue 52/2005). And in its Decision № 1/2020 (promulgated SG, issue 13/2020) the Constitutional Court accepted that „Budget laws contain general (abstractly formulated) rules of conduct, which within their termination period have repeatedly action and apply to an individually indefinite circle of subjects, i.e. they contain legal norms that regulate public relations. Notwithstanding the special way of formulation in its revenue-expenditure part, from the point of view of its legal-logical content these norms are on a general basis commanding (create an 
obligation to provide revenues), empowering (create rights to incur expenses) and prohibiting (prohibit the incurrence of expenses, not specified in them or above the amount, determined by them). The specificity of the budgetary norm is only in its subject of regulation and in its scope, limited through a term of termination.". Kostov (1976) took a diametrically opposite view, according to which the state budget as a whole is a legally binding state general non-normative planning act, which has the supreme legal force of law. In his justification, he refers to the distinctions between laws-regulations and laws-plans, emphasizing the one-year effect of the latter. He accepts that the place of normative provisions is in the permanent financial and budgetary legislation. In our opinion, however, when defining the legal nature of the law on the state budget, it should be taken into account the distinction between a law in the material sense and a law in the formal sense.

\section{State budget in the budget system of the Republic of Bulgaria}

The terms „,budgetary structure“ and „,budgetary process“ are used as synonyms of the concept „budget“, without being legally defined. There is no consensus in determining the content of these concepts and among the representatives of financial and financial law science. Most often, the content of the concept of „budget structure“ is presented through the organization of the budget system and the principles of its construction (Drobozina, Okuneva, Androsova et al., 1997; Kovaleva, Barannikova, Bogacheva et al., 1997). In other words, it represents the organization and the principles for structuring and functioning of the state budget system (Rayzberg, Lozovsky \& Starodubtseva, 2007). According to N. I. Himicheva, the budget structure includes ,main principles based on legal norms for building the budget system, its structure and organization of the interaction of budgets included in it" (Himicheva et al., 2005, p. 178).

In science, it is considered indisputably that the budget structure of each country is determined by its administrative-territorial structure (Gorbunova, O. N. et al., 2000; Chirkin, 2000; Parygina \& Tedeev, 2005). In unitary states, the budget system includes two units: the state budget and numerous municipalities' budgets. In federal states, the budget system consists of three subsystems:

- $\quad$ state budget (federal budget or Central Government budget);

- $\quad$ budgets of the members of federation (in the USA - states, in Canada - provinces, in Germany - provinces, in Russia - various subjects of the federation, such as republics, autonomous regions, districts, regions, etc.);

- local budgets.

In the confederations, which are a union of sovereign states, the member states of the confederation have their own budget systems. At the same time, a budget of the confederation was created, formed by contributions of its member states. An example in this direction is the Union of Russia and Belarus, whose union budget is formed by the contributions of its member states. The budget of the European Union is built on a similar principle, except that the European budget has its own tax and non-tax revenues.

According to A.N. Kozyrin (1993), the structure of the budget system is one of the most important characteristics of budget structure of the state. The term ,system" means that there is a whole entity, made of many elements, relating to each other in a certain way. This raises the question of the internal structure of the budget system. It includes the totality of budgets and extra-budgetary funds. These are the elements of the budget system in the narrow sense. In a broad sense, the subsystem of the subjects, holders of budgetary competence - the state and the municipalities, the subsystem of the state bodies and bodies of local self-government participating in the budgetary legal relations, the funds and the extra-budgetary accounts are also included. 
The structure of the budget system of Bulgaria is predetermined by the text of Art. 2, para. 1 of the Constitution (1991), which pronounces that „The Republic of Bulgaria shall be an unitary State with local self-government and no autonomous territorial formations shall be allowed to exist therein.". The content of this text shows that Bulgaria is a unitary state and therefore its budget system should have two main subsystems: state budget and local budgets.

According to B. Grozdanov (2001), a budget system is understood as the whole set of budgets of the central and local bodies and of their subordinate units, united in a single state budget. This statement, in our opinion, is also limited because it excludes from the budget system the budgets of public authorities outside the executive and extra-budgetary funds. Extrabudgetary funds are inherently close to the budget in that they arise by law and are approved by the legislative body (National Assembly), are compiled in accordance with the unified budget classification, and the reports of extra-budgetary accounts and funds are prepared and submitted together with the reports on the implementation of the respective budgets and budget accounts. The control over the extra-budgetary funds is carried out by the competent bodies in accordance with the procedure, established for the state budget.

Off-budget resources shall be raised and expended through funds and off-budget accounts with a credit and debit sides, which as we mentioned erlier, shall be prepared in accordance with the uniform budget classification. At the same time, we need to notice that off-budget resources differ from the budget, be it state or local, in their specific purpose and legal regime. Each fund shall be endorsed by the Council of Ministers acting on a motion by the competent primary spending unit coordinated with the Minister of Finance, unless otherwise provided in the law for their creation. The off-budget accounts within the scope of the executive budget with the exception of any such accounts opened according to the procedure established by Article 45 (2) of State Budget Procedures Act (SBPA, 1996) shall be endorsed by the Minister of Finance, acting on a motion by the competent first-level spending unit.

Part of the budget system is the budget of the National Assembly and the judiciary. The independent budget of the National Assembly is part of the state budget of the Republic of Bulgaria. By Definition of 3 December 1993, the Constitutional Court (CC) accepted for consideration the request for interpretation of Art. 117, para. 3 of the Constitution (1991) and judged to limit its interpretive activity only to the problem of the independence of the budget of the judiciary (Decision № 18 of 16.12.1993 on c. case № 19/1993 of the Constitutional Court). According to this Decision, the court accepted that „the interpretation of Art. 117, para. 3 of the Constitution (1991) presupposes clarification of the relation between the two norms of the Constitution (1991), which regulate budgetary matter - Art. 117, para. 3 and Art. 106 of the Constitution (1991).“. According to Art. 106 of the Constitution (1991) the Council of Ministers is assigned „to manage the implementation of the state budget". This norm has a general content, which concerns the state budget, but on the other hand, the norm refers to only one of the stages of the budget process - its implementation. The Constitution as a whole is also sparing with regard to the other stages of the budget process. Art. 87, para. 2 of the Constitution (1991), formulates the obligation of the Council of Ministers to „prepare“ and „submit" the draft of the annual state budget to the National Assembly. The constitutional texts concerning the budget process tacitly presuppose that the subject legal regulation of the competence of the Council of Ministers in the phase of drafting the state budget and its implementation is left to the ordinary legislation (for the respective structural budget law). According to the Decision of Constitutional Court, the norm of Art. 117, para. 3 of the Constitution (1991) has as its principal purpose to separate the budget of the judiciary from the budgetary competencies of the Council of Ministers under Art. 106 of the Constitution (1991), in order to ensure its independence. In this sense, the budget of the judiciary is independent 
and therefore both its compilation and implementation are outside the sphere of executive power (the Council of Ministers, respectively the Ministry of Finance). But the autonomy of the judiciary's budget does not infringe on the budgetary powers of parliament. The National Assembly adopts the state budget and the report on its implementation (Article 84, item 2 of the Constitution, 1991), and an integral part of the state budget is the independent budget of the judiciary (Decision № 18 of 16.12.1993 on c. case № 19/1993 of the Constitutional Court).

The issue, concerning the place of social and health insurance funds in the financial system and the place of the norms, regulating their budgets, is topical from a theoretical and practical point of view. By their purpose, these funds, as monetary funds in material terms, are social insofar as they are intended for the implementation of a set of social, constitutionally enshrined rights of citizens and the corresponding financial support of programs in the field of social, medical and health insurance. In organizational terms, they are non-profit organizations and enter into various legal relationships, including financial. In particular, they are participants in legal relations on the formation and implementation of the budgets of these funds. Relations regarding the formation, distribution and use of social and health funds are regulated by budget law, insofar as these funds are part of the budget system, although these budgets are not part of the state budget and are approved as separate budgets by separate laws.

The authors, who refer the state social funds to the composition of the budget system, refer the financial legal norms, regulating their formation, distribution and use to the institute of budget law. Other authors accept that the funds are an independent element of the financial system and that there is an independent structural subdivision of the financial law system, regulating the functioning of these budgets. In accordance with this two-dimensional understanding of the state social and health insurance funds, there are two financial and legal regimes of the functioning of the budgets of these funds: material and organizational. In the first case it is an independent legal institute, regulating the relations related to the formation, distribution and use of the budgets of the state social and health insurance funds as an independent unit of the financial system. In the second case, it should be taken into account as a set of financial legal norms with different sub-sectoral and institutional affiliation, regulating the financial powers of the controlling bodies of the state social and health insurance funds.

Taking into account the dual nature of the term „fund”, the differentiation of the financial regulation of functioning of these funds should also be considered carefully. If we consider them from a material point of view, then the set of legal norms regulating the formation, distribution and use of budgets of state social and health insurance funds, we should refer them to an independent financial law institute. However, in the case of financial legal relations carried out by financial authorities, these public relations with their participation are regulated by financial legal norms with different intra-industry affiliation (for example, relations concerning the exercise of financial control and realization of legal responsibility). The relations for establishing and collecting obligatory payments to the budget /taxes, duties, fees/ in the financial law are traditionally separated from the relations, regulated by the budget law. The taxpayer's tax liability is considered for fulfilled, as a general rule, from the moment of receipt of the amount on the payment account to the budget. While the relations on the formation of the revenues of the state and local budgets, as well as of the social and health insurance funds arise after the crediting of these amounts to the respective budget. Therefore, the relations related to the regulation of funds, similar to the relations, subject to tax law, should be regulated by a separate sub-branch of financial law - budget law.

In summary, the budget system can be defined by the following characteristics:

- $\quad$ in material aspect - as based on public monetary relations;

- in organizational aspect - as a set of budgets and off-budget resources, structured according to legally established principles; 
- $\quad$ in legal aspect - as a set of budgets and off-budget resources and accounts, regulated by the norms of budgetary law, which have a public law character;

- in political aspect - as a system, based on the principles of the state system of the Republic of Bulgaria.

\section{Place of the state budget in the consolidated fiscal program}

In order to cover the normative regulation of the management of public resources at the national level, i.e. of the whole system of budgets, we should consider the parameters of summarized indicators of the so-called consolidated fiscal programme. The consolidated fiscal programme includes indicators of budgets and accounts for European Union funds, budget organizations, which are approved by various bodies. Normatively, there are currently three forms of management of public funds, which according to the Public Finance Act (PFA, 2013) are budget, accounts for European Union funds and accounts for external funds.

The National Assembly annually adopts three budget laws, which are submitted by the Council of Ministers - on the state budget, on the budget of the state social insurance and on the budget of the National Health Insurance Fund (NHIF).

As the state budget is not an independent structural unit, we should define its scope. The state budget shall include the central budget, the independent budgets of the National Assembly (Article 62, paragraph 2 of the Constitution, 1991) and the judiciary (Article 117, paragraph 3 of the Constitution, 1991), the budgets of the executive bodies, such as the Council of Ministers, ministries and other departments such as government agencies, commissions, etc. (Art. 42, para. 1 of the PFA, 2013), the budgets of the other state authorities, and the budgets of budgetary organisations. The state budget shall not include the independent budgets of municipalities (Article 141, para. 1 of the Constitution, 1991), the budgets of social security funds, and the budgets of budgetary organisations and the budget parameters of the other economically separated persons and business units included in the consolidated fiscal programme (Art. 42, para. 1 of the PFA, 2013). Among the most popular definitions of a state budget is that it is an annual financial plan or financial framework of the state, on the basis of which revenues are collected and expenditures are made. The Minister of Finance is responsible for the preparation of the state budget and coordinates the coordination of the indicators of the other budgets within the parameters of the consolidated fiscal programme.

At a local level, the municipal councils adopt the budgets of the municipalities, for the preparation of which the mayors of the municipalities are responsible. Municipal budgets, as a part of public finances, are also included in the consolidated fiscal programme.

The consolidated fiscal programme/CFP/ includes other budgets of independent budget organizations, such as those of the Bulgarian Academy of Sciences, the public institutions of higher education, the Bulgarian News Agency, the Bulgarian National Television and the Bulgarian National Radio and others. The state budget, the public social insurance budget and the budget of the National Health Insurance Fund shall be adopted by the National Assembly by means of separate legislative acts for the relevant budget year, while ensuring consistency between them. Municipal budgets shall be adopted by the municipal councils as per the procedure set out in this Act. The budgets of the Bulgarian Academy of Sciences, the public institutions of higher education, the Bulgarian News Agency, the Bulgarian National Television and the Bulgarian National Radio shall be adopted by their managing bodies in accordance with the laws regulating their status, while ensuring consistency of their fiscal relations and the state budget. The budget parameters of the other economically separated persons and business units included in the consolidated fiscal programme shall be adopted by their managing bodies in accordance with the laws regulating their status, while ensuring 
consistency of their fiscal relations and the state budget. The CFP could be illustrated with the following diagram:

\section{Figure 1. Consolidated Fiscal Programme}

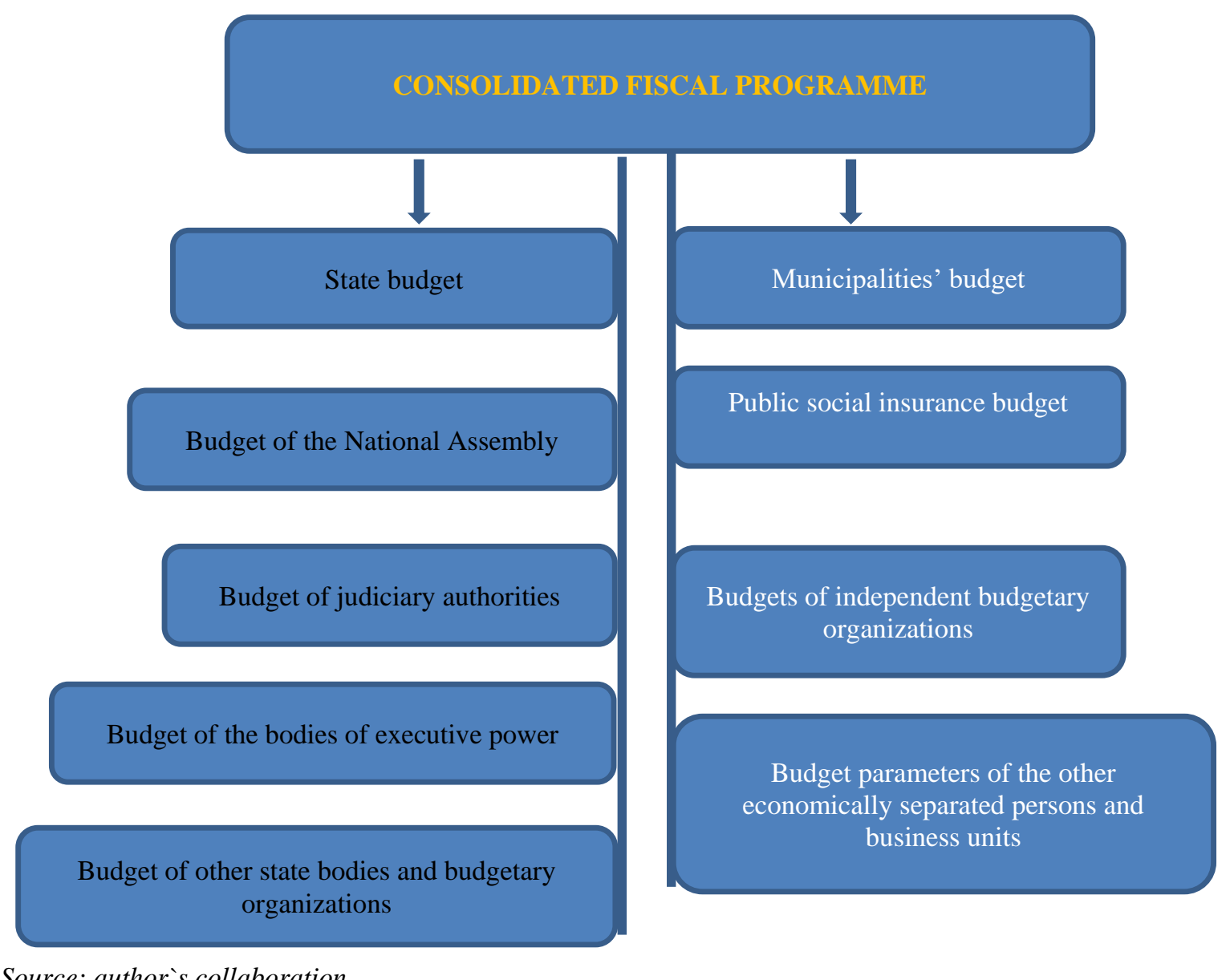

Source: author`s collaboration

The budgets of budgetary organisations are annual financial plans, which incorporate all proceeds and payments concerning their activity for the relevant budget year (according to art. 10, para 2 of the PFA (2013) it coincides with the calendar year), excluding the proceeds and payments concerned with accounts for European Union funds and the operations with external funds for which accounts for external funds have been designated according to the requirements set out in this Act.

The central budget shall incorporate proceeds and payments which are not included in the other budgets of the consolidated fiscal programme (art. 6, para 2 of the PFA, 2013), and shall be administered by the Minister of Finance as per the requirements set out in Public Finance Act (2013) and the state budget act for the relevant year, and in compliance with the instruments of the Council of Ministers (art. 12, para 2 of the PFA, 2013). On the basis of a law or statutory act of the Council of Ministers, specific proceeds and payments of the central budget may also be administered by other budgetary organisations (art. 12 of the PFA, 2013). The central budget is also used to envisage the expenditures and provide funding for the other budgets, included in the consolidated fiscal programme, as well as for other persons. The expenditures are made under the rules of Public Finance Act, the State Budget Act for the relevant year or an act of the Council of Ministers. According to an argument from Art. 86, 
para. 2 of the PFA (2013), the indicators of central budget are not explicitly included in the adopted law on the state budget for the relevant year.

Budgets and accounts for European Union funds are prepared in compliance with the requirements, rules, procedures and responsibilities set out in the so-called „framework" or „structural“ law. Since the beginning of 2014, this has been the Public Finance Act (PFA, 2013) - a modern law whose purpose is to ensure that the drawing up, adoption, implementation and reporting of the state budget are public and transparent. In order to be created conditions for guaranteeing the fiscal rules of the Public Finance Act (2013) and to be maintained sustainable public finances, in 2015 a Law on the Fiscal Council and Automatic Corrective Mechanisms (2015) was adopted. By establishing fiscal rules and restrictions in the Public Finance Act (2013), our public finance legislation has fulfilled the requirements of Council Directive 2011/85 / EU of 8 November 2011 on requirements for budgetary frameworks of the Member States (Official Journal of 23 November 2011, L 306/41). The establishment of national digital fiscal rules and restrictions in the Bulgarian budget legislation is a long tradition. With the amendments in the PFA (2013) in 2016, the digital fiscal rules for the municipalities were updated (for the amount of new expenditure obligations and commitments) and in connection with the introduction of procedures for rescuing municipalities with financial difficulties.

The budget system is characterized not only by the system of budgets and off-budget resources and funds, but also by the principles for its establishment, enshrined in the budget legislation. This definition of a budget system reveals its content as an economic and legal category in the narrow sense. In a broad sense, the budget system is a system of public relations, regulated by the rules of law, arising within the budget process, based on legally defined principles. These principles, according to PFA (2013), are legality, expediency, economy and publicity. According to PFA (2013), these principles are:

- comprehensiveness - the management of public finances is carried out through budgets and accounts of the budget organizations, included in the consolidated fiscal programme, and monitoring of the other persons from the sector „General Government“;

- accountability and responsibility - public finances are managed in a way that ensures the accountability and responsibility of budget managers;

- adequacy - compliance of fiscal policy with macroeconomic and socio-economic objectives;

- economy - the acquisition with the lowest costs of the necessary resources for the implementation of the activities of budgetary organizations in compliance with the requirements for quality of resources;

- effectiveness - the achievement of maximum results from the resources, used in carrying out the activities of budgetary organizations;

- efficiency - the degree of achievement of the goals of the budget organizations in comparing the actual and expected results of their activity;

- transparency - creating an opportunity for public awareness by providing public access to information on macroeconomic and budgetary forecasts, to data on the current implementation of the consolidated fiscal program, as well as on the methodologies /assumptions used in their drawing up/;

- sustainability - maintaining current levels of revenues and expenditures without risk to the state's solvency or ability to meet long-term liabilities;

- legality - compliance with applicable law, internal acts and contracts.

Other principles of the budget system, although they are not explicitly formulated in the law, are: unity of the budget system, autonomy of budgets, full reflection of revenues and expenditures of budgets, balance of the budget, general coverage of budget expenditures, targeting and targeted nature of budgetary costs. 


\section{Budget process}

The legal framework of the budget process in our country is contained in the State Budget Procedures Act (1996, repealed) and in the Municipal Budgets Act (1998, repealed), and at present - in the Constitution (1991) and the Public Finance Act (2013), as well as bylaws and acts of local authorities. The State Budget Procedures Act (repealed) regulated the process of drawing up, adoption, implementation and reporting on the implementation of the state budget, and the Municipal Budgets Act (repealed) - the municipal budgets, as each municipality has its own budget. The legal regulation of the budget process is based on the basic principles of the budget process and in particular such principles as annuality (short-term) of the budget, specificity (specialization) of the budget indicators and publicity of the budget. The budget process is currently regulated in one normative act and that is the Public Finance Act (2013).

The principle of annuality of budget requires that the budget should be drawn up, adopted and implemented for a period of one year. In different countries this term is the same, but if in our country the budget year begins on January 1 and ends on December 31, then in many countries the beginning and end of the budget year are different. For example, in Italy, the budget year begins on 1 July and ends on 30 July of the following year; in the United Kingdom from 1 April to 31 March of the following year; in the United States from October 1 to September 30 of the following year. In some countries, however, it begins on July 1 and ends on July 30 next year, and in others - from 1.IV. to 31.III. the following year, in the third from 1.X. to 30.IX. next year. There are other budget periods such as 1.V. - 30.IV. the following year in Turkey, 21.III. - 20.III. the following year in Iran, 10.IX. - 9.IV. the following year in Ethiopia (Lomnicka, 2003).

When the budget period does not coincide with the budget year, the aim is to bring it into line with the cycle of the financial year. The trend is towards calendarization of the budget period. It should be borne in mind that not all countries implement a one-year budget period. There are also countries (Flemish countries, Lebanon, Zaire, Indonesia, etc.) that draw up their budgets for two years, i.e. their budget period is two years. The discrepancy between the budget year and the calendar year in the different countries is explained by ,the historical traditions, the peculiarities of the national economy and the term of the parliamentary sessions" (Kozyrin, 1993, p. 45).

In case the budget is not adopted by the beginning of the next budget year, according to the State Budget Procedures Act (repealed) the budget revenues are collected in accordance with the current laws, and the expenditures are made in amounts not exceeding the expenditures for the same period of the previous year and taking into account entered into force normative acts of the National Assembly and the Council of Ministers, which provide for additional or reduced budget resources. This provision may not be applied for more than three months. Such a situation existed in our country in 1997, when due to the non-adoption of the Law on the State Budget of the Republic of Bulgaria for 1997, the Law on Budget Execution was adopted until the entry into force of the Law on the State Budget of the Republic of Bulgaria for 1997.

The principle of specificity (specialization) of budget indicators means that all budgets and off-budget resources are compiled on the basis of the unified budget classification. The budget classification is a mandatory ,grouping of revenues and expenditures on common grounds by assigning the individual sections of the budget to exact names and serial numbers" (Gorbunova, Selyukov \& Drugova, 2002, p. 121).

The principle of publicity and publicity of the budget is associated with the requirement to publish the budget and the report on its implementation, completeness of information on the progress of its implementation. The principle also requires mandatory openness and transparency of the procedures for reviewing and deciding on draft budgets, including on issues 
that cause disagreements within the representative body or between the executive and representative bodies.

The implementation of the goals and functions of the state is related to the availability of funds, financial resources, which are concentrated in the budget. In the course of the mobilization of these funds and their use, financial and budgetary relations arise between the state, the taxpayers and the recipients of budget funds. These relations are built in accordance with the financial and budgetary policy, developed and implemented by the authorities. The financial and budgetary policy includes actions of the state and local authorities in the different areas of finance - budgetary, tax, monetary, price, currency, etc. For the purposes of our study, we will analyze the actions, taken in the budget area.

The financial and budgetary policy presupposes the definition of the goals and tasks in the field of public finances, the development of the mechanism for mobilizing funds in the budget, the choice of guidelines for spending the funds, the management of public finances and the budget system, the organization with the help of financial budgetary instruments the regulation of the actions of budget subjects. The budgetary policy is implemented in the course of the activity of the authorities on mobilization of funds in the budget and their use, i.e. in the course of the budget process. The budget policy of the state is determined annually by the Law on the Budget of the Republic of Bulgaria for the relevant year, and at the local level - by the decisions of the Municipal Councils, which adopt the annual municipal budget.

\section{Budget process and state budget}

The budget process is regulated by the norms of legal activity of state authorities, local governments and participants in the budget process for drafting, adopting draft budgets, draft budgets of state off-budget resources, approval and implementation of budgets and budgets of state off-budget resources, as well as the control over their implementation (Rumyantsev \& Dodonov, 1997).

The budget process, starting from the moment of drawing up the draft budget and ending from the moment of the adoption of report on the implementation of the annual budget, is regulated by the norms of the budgetary (procedural) law. According to O.N. Boltinova „Budget process - this is, regulated by the norms of procedural budget law, activity of the state on drawing up, reviewing and approving the budget, its implementation and completion, as well as developing, reviewing and approving the report on budget implementation." (Boltinova, 2005, p. 222). And according to O.B. Shemyakina ,the budget process - this is, regulated by the rules of law, activity of the participants in the budget process for the drawing up, review, approval and implementation of budgets and off-budget funds, as well as development, review and approval of reports on the implementation of budget, as well as the control of each stage of the budget process." (Shemyakina, 2004, p. 12).

The set of legally regulated actions of the bodies of executive and representative power on the drawing up, adoption, implementation and reporting of the implementation of the budget, in our opinion, represents the budget process. „Objectively, the budget process is divided into stages, which could be understood as independently separated and completed stages of the activity of the participants in the budget process, as a result of which the budget passes from one quantitative state to another." (Piskotin, 1971, p. 63). The stages of the budget process change with each other, but their sequence cannot be changed, because at each stage issues are resolved that cannot be resolved at another time. 


\section{Stages of the budget process}

\section{/A/ Drafting the budget}

We have already pointed out that the budget period in our country coincides with the calendar year. However, the duration of the budget process is significantly longer than the budget period because it includes the time for budget planning actions, ex-post budgetary control and other actions.

Budget planning is usually carried out for a longer period, while budget projection is targeted and calculated for the budget period, i.e. for a period not exceeding one year. „Budget planning is carried out by authorized state authorities and includes the budget process, as well as issues of theory and methodology of state budgeting" (Dobrozina, Okuneva \& Androsova, 1997, p. 208). A budget forecast is a set of probabilistic estimates of the possibilities for development of the revenue and expenditure part of the budget. The purpose of the budget projection is to develop and justify an optimal budget on the basis of the derived trends, specific socio-economic conditions and perspective assessments. Budget planning, according to the Law on Budget (repealed), is carried out by the Council of Ministers, and according to the Law on Budget, the preparation of the medium-term budget projection for 3 years and the draft state budget is organized by the Council of Ministers through the Minister of Finance. The Ministry of Finance shall prepare a budget projection proceeding from economic elaborations and analyses made thereby and by other institutions of the behaviour of the gross domestic product, prices, incomes, the credit policy and foreign-exchange policy and the main financial results of the operation of the state-owned, municipal-owned and private economic entities. According to the requirement of the PFA (2013), by January 31, on the basis of proposal of the Minister of Finance, the Council of Ministers adopts the budget procedure for compiling the mediumterm budget projection and the draft state budget for next year (Decision № 52 of the Council of Ministers of 31.01.2019 on the budget procedure for 2020). The budget procedure includes the stages, deadlines, distribution of responsibilities and requirements for the preparation of the medium-term budget projection and the draft state budget. The basis for development of the budget projection of the Primary Budget Managers (PDB) are the Law on the State Budget of the Republic of Bulgaria for the previous year, the expenditure ceilings under the PDB for the period adopted by the Council of Ministers and the Updated Medium Term Budget Projection for the period, as well as the instructions of the Minister of Finance.

Drafting the budget is a prerogative of the government, the Ministry of Finance and the executive bodies of the local government. On the basis of the budget projection and the budget guidelines for drafting annual budgets of state bodies, state and local authorities draw up a draft budget.

The budgetary procedure at this stage includes the following main points:

- February - The Minister of Finance prepares a preliminary assessment of key macroeconomic indicators for the period and gives instructions to the First-level spending units for preparation and submission of their budget projections for the period. Proposals for standards for financing the activities delegated by the state through the municipal budgets are being developed.

- March - The First-level spending units develop and submit to the Ministry of Finance its budget forecasts for the period, those with a program budget - their budget forecasts for the period by policy areas/functional areas and budget programs. The ministers, responsible for the implementation and coordination of the national strategy and policy in the relevant field, shall develop and submit to the Ministry of Finance their budget forecasts for the period for the activities, financed through the budgets of the budget managers. Proposals are made for the natural indicators for the activities delegated by the state, financed through the municipal budgets, for the period. The First-level spending units, responsible for the management of the 
financial assistance provided to the Republic of Bulgaria by the European Union and other donors, develops and submits to the Ministry of Finance motivated forecasts and estimates for the absorption of funds financed by EU funds. The mayors of the municipalities develop and submit to the Ministry of Finance their budget forecasts for the period in the part for local activities. The ministers and mayors of the municipalities provide to the Ministry of Finance summarized information and assessment of the forecasts for the legal persons, controlled by the state and/or the municipalities, falling within the scope of the General Government sector for the period, as well as for the legal entities, controlled by the state and/or the municipalities, with a total amount of liabilities by December 31 over $0.1 \%$ of GDP, which are not part of the consolidated fiscal program and do not fall within the scope of the General Government sector. The National Social Security Institute and the National Health Insurance Fund prepare the revenue part of their budget forecasts for the period, in coordination with the National Revenue Agency.

- March - The Minister of Finance prepares the spring macroeconomic forecast for the period.

- April - The Minister of Finance coordinates the draft of the medium-term budget forecast for the period with the First-level spending units, the National Association of Municipalities in the Republic of Bulgaria and the Fiscal Council. The Minister of Finance prepares and submits to the Council of Ministers for consideration a draft decision approving the medium-term budget forecast for the period, as well as a draft motives for not adopting the reasoned opinion and recommendations of the Fiscal Council on the spring macroeconomic forecast and/or medium-term budget forecast for the period, for the adoption of standards for the activities, delegated by the state, with natural and value indicators and the government submits the adopted package of documents for information to the National Assembly.

- August - The Minister of Finance prepares a preliminary assessment of key macroeconomic indicators for the period. By September, it gives instructions to the First-level spending units and sets deadlines for the preparation and submission of their annual draft budgets and their updated budget forecasts. The Ministry of Finance evaluates the draft budgets and the updated budget forecasts of the relevant units. The Ministry of Finance prepares bills to amend the tax laws.

- October - The Ministry of Finance publishes on its website the autumn macroeconomic forecast, including the main assumptions on which it is based. The Minister of Finance is developing the draft law on the state budget of the Republic of Bulgaria, the draft of the updated medium-term budget forecast for the period, representing motives to the draft law on the state budget. It notifies the units of the main parameters of their draft budgets and their expenditure ceilings. The Chairman of the National Council for Tripartite Cooperation convenes a meeting to discuss the draft law on the state budget of the Republic of Bulgaria. The Minister of Finance prepares and submits to the Government for consideration and approval a draft Law on the State Budget of the Republic of Bulgaria together with the budget documents, including the program formats of budgets of the First-level spending units and the draft updated medium-term budget forecast for the period. The Council of Ministers holds a session, where it considers and approves the submitted budget acts, and by October 31 submits the bill on the state budget of the Republic of Bulgaria together with the budget documents to the National Assembly, including the updated medium-term budget forecast for the period.

From what has been said so far, we could conclude that there is a monopoly of the executive branch on the preparation of the draft budget. This allows the implementation of the budget to be made dependent on various technical calculations, tricks and even manipulations by the government, allowed in the course of drawing up the draft budget. The use of only the medium-term fiscal framework and the macroeconomic forecast prepared by the government 
in the preparation of the draft budget significantly reduces the role of parliament in the budget process. In this regard, it should be noted that in the United States, for example, in addition to the economic forecasts of the Office of Management and Budget, the Congress uses the economic estimates of the Congressional Budget Office and the Joint Congressional Tax Committee of taxation (Collender, 1998). In a view of this, we believe that the National Assembly may use additional alternative sources of information when discussing the budget for example, from specially created committees or other bodies, as well as from organizations in the non-governmental sector.

\section{/B/ Adoption of the budget}

The draft state budget, which the Council of Ministers submits to the National Assembly no later than two months before the beginning of the budget year, is accompanied by a consolidated fiscal programme. If the state budget is not submitted in the necessary time to be adopted by the beginning of the budget year, the Council of Ministers shall present reasons for the delay and request permission from the National Assembly to extend the term for the preparation of the draft budget. The draft law on the state budget shall be considered in accordance with the procedure established by the Rules of Organization and Procedure of the National Assembly (2017).

As we mentioned above, upon consideration of the bill, the standing committee in charge of the budget shall consolidate the observations of the other standing committees of the National Assembly and the motions of the national representatives and shall pass on the said observations and motions without revising the balance of receipts and outlays as moved. Upon request of the standing committees of the National Assembly, the ministries, centralgovernment departments and other state bodies shall furnish supplementary fact sheets and explanations on receipts and outlays. The National Assembly shall hear a report of the Council of Ministers, presented by the Minister of Finance, and a report of the standing committee in charge of the budget, whereupon the National Assembly shall debate the draft of the annual State Budget Act.

When reviewing the public social insurance budget, the National Assembly shall hear a report of the departmental minister, a report of the Governor of the National Social Security Institute, and a report of the committee responsible for the budget. The budget of the National Health Insurance Fund is adopted according to the main indicators under Art. 14 of the PFA (2013) and must contain the elements applicable to it under Art. 89, para. 3 of the PFA (2013). The amount of health insurance payments is indicated on a separate line. The budget of the National Health Insurance Fund in terms of expenditures may also be adopted by policy areas and/or budget programs. Under the rule of Art. 86 of the PFA (2013), the state budget shall be adopted by a legislative act after the consideration of the draft budget for the state budget in the National Assembly and after observance of the procedure regulated in the Rules of Organization and Procedure of the National Assembly (2017). It is published in the State Gazette by a presidential decree. The Council of Ministers, upon a proposal of the Minister of Finance, within one month from the promulgation of the annual law on the state budget, shall adopt a decree for its implementation. The decree specifies the indicators for the budgets, included in the state budget, with the exception of the budgets of the National Assembly and the judiciary authorities. The decree also specifies the indicators for the individual budget programs in the budgets of budget organizations, which apply a program format of the budget within the expenditures, approved by the annual law on the state budget by policy areas and/or budget programs. Budgetary organizations publish their approved budgets on their official website in compliance with the requirements of the Classified Information Protection Act (2002). 
The accounts for European Union funds shall not be included in the state budget, municipal budgets, or any other budgets under Art. 141 of the PFA (2013). The accounts for European Union funds may be used for pre-financing of payments to the relevant beneficiaries (budgetary organisations) in the form of interest-free loans as per the procedures and within the time limits set out by the Minister of Finance. Estimates are compiled, approved and updated for the accounts for the EU funds (Art. 144, para. 1 of the PFA, 2013). These estimates for the accounts for EU funds of the municipalities are prepared by the mayor of the municipality and approved by the Municipal Council. The constituent element of the budget in the form of ,budgetary relations“ with the central budget and with other budgets and accounts for EU funds, regulated in Art. 45, para. 1 item 3 of the PFA (2013), by legal definition from $\S 1$, item 4 of the Additional Provisions of the PFA (2013) includes transfers and temporary interest-free loans. The terms ,transfers“ and „temporary interest-free loans“ are defined in $\S$ 1, item 8 and item 39 of the Additional Provisions of the PFA (2013). Transfer means a transfer of cash on a non-refundable basis between the central budget, the budgets, the accounts for European Union funds and the accounts for external funds, and loan means any repayable cash extended between the central budget and the budgets and accounts for European Union funds, For budgeting and reporting purposes, temporary interest-free loans shall be presented as transfers.

\section{/C/ State budget implementation}

The next stage of the budget process is the implementation of the budget. In a broad sense, state budget implementation is the process of mobilizing human, material, and financial resources using certain methods and procedures (Premchand, 1983). In a narrow sense, budget implementation as a stage of the budget process means mobilizing all planned budget revenues and financing the planned expenditures (Kozyrin et al., 2002).

The main task of the budget implementation process is to solve all tasks related to the spending of budget funds - financial and economic. It includes actions for the mobilization and use of funds, in the process of which involve the executive authorities, financial authorities, revenue administration bodies, individuals and legal entities with financial obligations to the budget and the recipients of budget funds. According to Rizhkova (2004, p.429-430), „two aspects of budget execution stand out: financial and legal. The financial aspect is related to the activity of the treasury or the Central Bank, and the legal aspect - to the principles for implementation of the budget and the procedure for the implementation of the revenue and expenditure part of the budget.".

In the world practice there are three known systems for budget implementation treasury, banking and mixed - treasury-banking, which is a combination of the first two.

The treasury system is historically the older system. Under it, the cash execution of the budget was carried out through tax cash registers, opened and organized at the tax offices, departments and offices. It is characteristic that the treasury system for cash execution of the budget is applied in combination with the so-called fund beginning of budget management formation of separate revenue forms of separate budget funds to finance specific expenditures. In other words, the revenues had a strictly targeted nature, which determines the formation of various target budget funds.

The banking system for cash implementation arises and is formed with the gradual establishment of the cash execution of the budget as one of the main functions of the banks and with the transformation of the national bank into the cashier of the state. Under this system, under the authority of the state, the banks under the direction of the national bank collect the state revenues, keep the funds in special budget accounts and pay expenses from them at the order of the competent spending units. It is in the banking system for cash execution of the 
budget that objective conditions arise for the creation of a common or unified budget „cash register". According to the State Budget Procedures Act (repealed), the state budget of the Republic of Bulgaria is implemented on a cash basis. The cash execution of the state budget is organized and carried out by the Bulgarian National Bank in accordance with the procedure set forth in the Law on the Bulgarian National Bank.

The budget is implemented on the basis of the following principles:

- Distinguishing between the functions of authorized spending officers and accounting officers - According to this principle, budget implementation is entrusted to two different agents, hierarchically independent of each other and performing different but complementary functions, which are, however, incompatible with each other. In this way, the budget is implemented by different entities - administrators, authorizing spending officers and accountants.

- Unity of the treasury - This principle provides for the crediting of all incoming revenues to a single budget account and the implementation of all planned expenditures through a single account of the Ministry of Finance in the Central Bank

- Ensuring the budget expenditures and payments within the limits of the actual availability of funds in the budget account - According to the text of Art. 31, para. 2 of the State Budget Procedures Act /repealed/ the expenses shall be made up to the amount of the received revenues on the bank accounts of the republican budget and the spending units.

The Council of Ministers shall organise the implementation of the executive budget through the Ministry of Finance and the state bodies which are first-level spending units.

Under art. 11, para. 1 of the PFA (2013) budget authorisers shall be the heads of budgetary organisations or, in the case of collective bodies, their chairperson, unless otherwise provided by law. The First-level budget authorisers determine the budgets of the secondary budget authorisers, approve them insofar as the PFA (2013) or another law does not stipulate otherwise. Secondary Budget Authorisers determine and approve the budgets of lower-level budget authorisers. The Minister of Finance gives instructions on the implementation of the state budget and the accounts for funds from the European Union. The instructions are published on the website of the Ministry of Finance.

The cash implementation of the budget by the BNB means that the operations with the budget funds for crediting revenues to the budget and payments at the expense of the budget are performed by the BNB or an authorized bank in which a budget account is opened. The cash implementation of the state budget, including the storage of cash and valuables, is carried out free of charge, observing the sequence of payments to the budget, established by law. The Minister of Finance and the Governor of the Bulgarian National Bank shall issue an ordinance on the cash execution of the state budget, the budgets of the municipalities and the funds and the extra-budgetary accounts.

The implementation of the revenue part of the budget includes:

- collection and crediting of funds to the budget account;

- reporting of revenues in the budget in accordance with the unified budget classification.

These two activities in the State Budget Procedures Act (repealed) are included in the concept of ,revenue administration”. According to its Additional Provisions $\S 1$, item 3 the administration of revenues is an activity for collection and reporting of revenues in the state budget.

The implementation of the expenditure part of the budget provides for procedures for sanctioning and financing the expenditures. The sanctioning of expenditure includes the approval of appropriations and the approval of budget commitments. The financing of the 
expenses is carried out after obtaining a permit for drawing up the payment document by making the payment itself.

In the process of the implementation of the budget, changes in the planned amounts of expenditures are possible. The principle, enshrined in the text of Art. 35, para. 1 of the State Budget Procedures Act (repealed), regarding the changes and adjustments in the budget accounts, is that they are possible, as long as the balance of the consolidated fiscal program does not deteriorate the balance of the state budget or the parameters of the approved budget for the relevant spending unit. It is possible to incur expenditures or assume obligations that worsen the balance of the budget only in cases when, upon the proposal of the Council of Ministers, the National Assembly has adopted relevant amendments in the annual law on the state budget.

In case of overfulfillment of the revenue plan, the additional funds received, the law stipulates that the Council of Ministers, upon proposal of the Minister of Finance, may approve additional budget appropriations in the amount of up to 1.5 per cent of the revenue statement under the consolidated fiscal programme for the relevant year, covered by overfulfillment of own revenues and/or by opening new sources of income.

Over the years, there has been a steady trend of overfulfillment of revenues in the state budget. In the period 2000-2004, the total overfulfillment of revenues was over BGN 3.3 billion, and in 2004 it was BGN 1.5 billion. This trend continues as for 2007 the cash overfulfillment of revenues was approximately BGN 1.2 billion. In 2017, the annual tax and insurance revenues exceeded the plan for the year by more than BGN 1.5 billion. Compared to 2016, they increased by nearly BGN 2.7 billion, as the revenues from the main taxes increased by more than BGN 1.6 billion. BGN, and the revenues from social and health insurance contributions reported an increase of over BGN 1.0 billion.

The legal mechanism for distribution of the over-execution of the budget revenues, based on the provision of art. 35, para. 2 of the State Budget Procedures Act (repealed), gives rights to the Minister of Finance to allow additional loans without sanction to the Council of Ministers. This right enabled individual decisions of the Minister to spend a relatively significant part of the gross domestic product of the Republic of Bulgaria. Additional budget appropriations above the amount, specified in the law, are approved by the National Assembly on the proposal of the Council of Ministers, when they are covered by overfulfillment of own revenues and/or opening of new revenue sources, without deteriorating the balance of the consolidated fiscal programme.

These overfulfillments of revenues and the way they are spent over time show that the legislation allows for the emergence of a tendency of incorrect attitude of the representatives of executive power and in particular - the Ministry of Finance, to the forecasting, compilation and implementation of the state budget. When planning the budget, the expected revenues are purposefully underestimated and since at this stage the control of the legislature is practically zero and there is no mechanism for influencing a control body in this process, a planned overexecution of the revenue part of the budget is ensured.

\section{/D/ Preparation, consideration and adoption of the report on budget implementation}

The last final stage of the budget process is usually associated as the stage of drawing up, reviewing and adopting the budget implementation report. According to O.V. Boltinova, ,the concept of budget process must include the stage of preparation, review and approval of reports on budget implementation, as an inseparable stage of the budget process" (Boltinova, 1999, p. 57). 
In the process of budget implementation, all revenues, expenditures, budget deficits, as well as all operations on it are registered in the budget report, prepared by the financial authorities. The budget report is kept on the basis of accounting standards in accordance with the uniform budget classification. Budget reporting can be operational, periodic and annual. The financial authorities shall draw up a report on the implementation of their budget on the basis of the accounts of the authorizing officer and the recipient. The procedure and deadlines for compiling the reports and their submission shall be determined by the Ministry of Finance in coordination with the National Audit Office. The Minister of Finance submits to the Council of Ministers information on the cash execution of the state budget and the main indicators of the consolidated fiscal programme for each quarter of the current budget year on the basis of monthly reports, submitted by the first-level budget units within 45 days from the end of the reporting period. period, unless another term is determined by an act of the Council of Ministers, as well as a report on the cash implementation of the consolidated fiscal programme for the first half of the current budget year by September 15.

The annual report on the implementation of the budget shall be subject to adoption by a representative authority. In our country this is the National Assembly. Prior to the adoption of the report by the Parliament, it is audited by the National Audit Office, i.e. an external audit of budget implementation is carried out. The National Assembly shall decide on the adoption of the report on the implementation of the budget upon receipt of the report of the National Audit Office on the implementation of the budget. During the discussion of the report on the implementation of the state budget in the National Assembly:

1. The Minister of Finance shall present the annual report on the implementation of the main indicators of the state budget, the implementation of the fiscal objectives, information on the implementation of the consolidated fiscal programme, as well as the annual report on the state of the state debt.

2. Ministers shall submit annual reports on the implementation of the policies which they are responsible for.

The National Assembly shall adopt by a resolution the report on the implementation of the state budget not later than December 31 of the year following the reporting year. Our legislation does not address the issue that would arise if in the course of the external audit of the budget implementation report a discrepancy was found between the prescribed expenditure and the expenditure incurred in practice and this circumstance was reflected in the report of the National Audit Office. It is possible that there is such a finding in the conclusion of the budget committee on the report on the implementation of the state budget. The practice in most countries is in these cases that the representative body does not accept the budget implementation report.

This gives a legal reason for the prosecutor's office to investigate the circumstances in which the budget legislation was violated and the guilty officials were brought to justice. PFA (2013) does not provide for such a possibility - it is only stated that the National Assembly adopts by a resolution the report on the implementation of the state budget, without indicating what should be done in the described hypothesis. Therefore, we make the following proposal de lege ferenda for amendment in the PFA (2013) - in the text of Art. 139 it is added para. 3, which proclaims: „If the National Assembly does not adopt with a resolution the report on the implementation of the state budget, it shall send the resolution to the respective competent body for bringing to justice the guilty officials or shall take measures for influence."

The analysis of the reporting stage of the budget implementation shows that in our country it is generally regulated. The participation of the parliament in the consideration and adoption of the report on the implementation of the budget is not detailed, the hypothesis related to the existence of deviations from its implementation in violation of the law is not considered, 
no mechanism for accountability of individual ministers to the parliament is provided. There is no legal requirement to submit a report on the results of the government's activities under its programs. For instance, reports in a number of countries are accompanied by reports on the results of the administration's activities, which have not only budgetary but also economic and social dimensions. According to French legislation, the draft budget implementation must be accompanied by the annual program report, containing information on the objectives, obtained and expected results, the losses, the job positions or their modification (Article 54 of the Organic Law of the French Republic from 01.08.2001 № 2001-692, „On the financial laws”). In the United States under the rules of E-government Act (E-government Act of 2002) all federal authorities are obliged to provide, using Internet technologies, to an unlimited number of persons information about the services they provide to consumers, the results of their activities, the applied best practices. The law stipulates an obligation for government bodies to provide information about their activities by target groups - for citizens, entrepreneurs and others. These examples show that the formation of state budget reporting goes beyond satisfying the interests of the legislator and the reporting activities of the government should be aimed at meeting the information needs of individual citizens and groups. We believe that the issue of the content of the report on the implementation of the budget should be discussed in our country so that it could satisfy the interests not only of the legislator, but also of various groups of society - public organizations, creditors of public bodies, experts and most - more to the citizens. Subsequently, it is necessary to make the relevant legislative amendments in this direction.

\section{/E/ Control over the implementation of the budget}

An extremely important element of the budget process is the control over the implementation of the budget. This control is carried out both with regard to the implementation of the revenue part of the budget and with regard to the implementation of its expenditure part.

The control over the implementation of the budget, carried out by the bodies of the representative power, by the judiciary, by the National Audit Office and by the bodies of the executive power is an extremely essential part of the budget process. There are three forms of control over budget implementation - parliamentary, judicial and administrative control.

Parliamentary control implies: the right of parliament to receive from the executive bodies the necessary accompanying materials and documents during the process of adopting and voting on the draft budget, as well as adopting the report on the implementation of the budget; the right to adopt or not to accept the report on the implementation of the budget and, in the second case, to take appropriate measures of impact; the right to set up an independent body outside the executive branch for the external audit of the budget; the right to evaluate the activity of the bodies of the executive power on the implementation of the budget.

Judicial control is exercised by the judicial system in the Republic of Bulgaria. This is a control over the legality of the activity of the subjects of budget law. It is carried out by the courts in accordance with their competences and powers in the administration of justice.

Administrative control is carried out by the bodies of the central and local executive power - the Council of Ministers, the Minister of Finance, the first-level spending units, the heads and chief accountants of the public sector organizations, the auditors. Administrative control supposes: legitimate powers for carrying out checks on authorizing officers and recipients of appropriations; obtaining information necessary for control over the observance of the budget legislation; giving mandatory instructions in detecting violations of budget legislation; the drafting of legal acts, which are used as motives for seeking legal liability from violators. 
At each stage of the budget process, control over the participants in the budget process is mandatory. That is why it is an integral part of each stage of the budget process. Moreover, it is not only control over the implementation of the budget, but also control at every stage of the budget process, carried out by the legislative, executive and judicial authorities, as well as by the specialized bodies for financial control.

\section{Conclusion}

The state budget, although by its legal nature it is a financial plan for the relevant budget year, has an important political significance. It provides the financial mechanism for the implementation of the government's program for the relevant year. This, in turn, presupposes a public debate on the state budget. In a parliamentary republic such as Bulgaria, the legitimate mechanism for this, with the corresponding legal consequences, is embedded in the public parliamentary debates, which constitute the second stage of the parliamentary legislative process, namely - discussion of the bill in the standing parliamentary committees and in the plenary session of Parliament. Therefore, it is necessary for the state budget to be adopted in the form of a law, following the established legislative procedure and taking into account its specific features, characteristic for the adoption of the law on the state budget. In practice, the legal institute of the state budget is a means of carrying out reforms in one or another social sphere. 


\section{References}

Baglay, M. V., Leybo, Yu. I. \& Entin, L. M. (2010). Konstitucionnoe pravo zarubezhnyh stran. Moskva: Norma. [Баглай, М. В., Лейбо, Ю. И. \& Энтин, Л. М. (2010). Конституционное право зарубежных стран. Москва: Норма.]

Bliznashki, G. (2007). Principi na parlamentarnoto upravlenie. Sofiya: UI „Sv. Kliment Ohridski”. [Близнашки, Г. (2007). Принциипи на парламентарното управление. София: УИ „Св. Климент Охридски“.]

Bliznashki, G. (2009). Parlamentarnoto upravlenie v Balgariya. Sofiya: UI „Sv. Kliment Ohridski”. [Близнашки, Г. (2009). Парламентарното управление в България. София: УИ „Св. Климент Охридски“.]

Bliznashki, G. (2015). Parlamentarno parvo. Sofiya: UI „Sv. Kliment Ohridski”. [Близнашки, Г. (2015). Парламентарно право. София:УИ „Св. Климент Охридски“.]

Boltinova, O. N. (2005). Finansovoe parvo. Moskva: Yurist'. [Болтинова, О. Н. (2005). Финансовое право. Москва: Юристь.]

Boltinova, O. V. (1999). Sovershenstvovanie pravovogo regulirovaniya stadia rassmotreniya i utverzhdeniya federal 'nogo byudzheta RF. Dissertaciya, Moskva. [Болтинова, О. В. (1999). Совершенствование правового регулирования стадии рассмотрения и утверждения федерального бюджета РФ. Диссертация, Москва.]

Bradshaw, K. \& Pring, D. (1981). Parliament and Congress. London: Quartet Books.

Chirkin, V. E. (2000). Konstitucionnoe pravo zarubezhnyh stran. Moskva: Yurist'. [Чиркин, В. Е. (2000). Конституционное право зарубежных стран. Москва: Юристь.]

Collender, St. (1998). The Guide to the Federal Budget: Fiscal. Rowman \& Littlefield Publishers Inc.: Lanham, Maryland.

Dobrozina L. A., Okuneva L. P., Androsova, L. D. (1997). Finansy. Denezhnoe obrashenie. Kredit. Moskva: Finansy, Yuniti. [Доброзина, Л. А., Окунева, Л. П., Андросова, Л. Д. (1997). Финансы. Денежное обращение. Кредит. Москва: Финансы, Юнити.]

Drumeva, E. (2018). Konstitucionno parvo. Sofiya: SIELA. [Друмева, Е. (2018). Конституциионно право. София: Сиела.]

Gorbunova, O. N. et al. (2000). Finansovoe parvo. Moskva: Yurist'. [Горбунова, O. H. et al. (2000). Финансовое право. Москва: Юристь.]

Gorbunova, O. N., Selyukov, A. D. \& Drugova, Yu. V. (2002). Byudzhetnoe pravo Rossii. Moskva: Velbi. [Горбунова, О. Н., Селюков, А. Д. \& Другова, Ю. В. (2002). Бюджетное право России. Москва: Велби.]

Grozdanov, В. (2001). Publichni finansi. Veliko Tarnovo: Abagar. [Грозданов, Б. (2001). Публични финанси. Велико Търново: Абагар.]

Himicheva, N. I. et al. (2005). Finansovoe parvo. Moskva: Yurist'. [Химичева, Н. И. et al. (2005). Финансовое право. Москва: Юристь.] 
Kostov, M. (1976). Konstitucionni osnovi na byudzhetnoto parvo. Sofiya: Izdatelstvo na BAN. [Костов, М. (1976). Конституционни основи на бюджетното право. София: Издателство на БАН.]

Kovaleva, A. M., Barannikova, N. P., Bogacheva, V. D. et al. (1997). Finansy. Moskva: Finansy i statistika. [Ковалева, А. М., Баранникова, Н. П., Богачева, В. Д. et al. (1997). Финансы. Москва: Финансы и статистика.]

Kozyrin, A. N. (1993). Nalogovoe pravo zarubezhnyh stran. Moskva: Manuskript. [Козырин, А. Н. (1993). Налоговое право зарубежных стран. Москва: Манускрипт.]

Kozyrin, A. N. et al. (2002). Kommentary k Byudzhetnomu kodeksu Rossyskoy Federacii. Moskva: Ekar. [Козырин, A. H. et al. (2002). Комментарий к Бюджетному кодексу Российской Федерации. Москва: Экар.]

Loewenstein, K (1965). Political Power and the Governmental Process. Chicago: University of Chicago Press.

Lomnicka, E. (2003). Tax law. Oxford: Oxford University Press.

Maurer, H. (2007). Staatsrecht I. Munich: C.H.Beck.

Pactet, P. (1992). Institutions politiques et Droit Constitutionnel. Paris: Masson.

Parygina, V. A., \& Tedeev, A. A. (2005). Byudzhetnoe pravo i process. Moskva: Eksmo. [Парыгина, В. А., \& Тедеев, А. А. (2005). Бюджетное право и процесс. Москва: Эксмо.]

Piskotin, M. I. (1971). Sovetskoe byudzhetnoe parvo. Moskva: Yurid. literatura. [Пискотин, М. И. (1971). Советское бюджетное право. Москва: Юрид. литература.

Premchand A. (1983). Government Budgeting and Expenditure Controls: Theory and Practice. Washington, DC: IMF.

Rayzberg, B. A., Lozovsky, L. Sh. \& Starodubtseva, E. B. (2007). Sovremennyy ekonomichesky slovar’: М., INFRA-М. [Райзберг, Б. А., Лозовский, Л. Ш. \& Стародубцева, Е. Б. (2007). Современный экономический словарь: М., ИНФРАM.]

Rizhkova, E. A. (2004). Finansovoe parvo. Moskva: Prospekt. [Рижкова, E. A. (2004). Финансовое право. Москва: Проспект.]

Rumyantsev, O. G., \& Dodonov, V. N. (1997). Yuridichesky enciklopedichesky slovar. Moskva: Infra-M. [Румянцев, О. Г., \& Додонов, В. Н. (1997). Юридический энциклопедический словарь. Москва: Инфра-М.]

Shemyakina, O. B. (2004). Kompetenciya zakonodatel'nyh /predstavitel'nyh/ organov gosudarstvennoi vlasti sub 'ektov RF v oblasti regulirovaniya byudzhetnogo processa. Avtoreferat kand. Diss., Moskva. [Шемякина, О. Б. (2004). Компетенция законодательных /представительных/ органов государственной власти субъектов РФ в области регулирования бюджетного проиесса. Автореферат канд. дисс., Москва.] 
Stoyanov, P. (1938). Byudzhetat na savremennata darjava. Sofiya: Svoboden universitet. [Стоянов, П. (1938). Бюджетът на съвременната държава. София: Свободен университет.]

Tanchev, Evg., \& Belov, M. (2009). Sravnitelno konstitucionno parvo. Sofiya: Sibi. [Танчев, Евг., \& Белов, М. (2009). Сравнително конституционно право. София: Сиби.]

\section{Regulations and Decisions}

Classified Information Protection Act (2002). Retrieved from https://www.legislationline.org/download/id/5513/file/Bulgaria_Protection_Classified Info_2002am2009.pdf.

Constitution of the People's Republic of Bulgaria (1947). Retrieved from https://www.academia.edu/6830294/CONSTITUTION_the_Peoples_Republic_of_Bu lgaria_from_12_06_1947_Chapter_I_Peoples_Republic_of_Bulgaria.

Constitution of the People's Republic of Bulgaria (1971) Retrieved from https://www.parliament.bg/bg/19.

Constitution of the Republic of Bulgaria (1991). Retrieved from https://www.parliament.bg/en/const.

Constitution of the Kingdom of Spain (1978). Retrieved from http://www.congreso.es/portal/page/portal/Congreso/Congreso/Hist_Normas/Norm/co nst_espa_texto_ingles_0.pdf.

Council Directive 2011/85 / EU of 8 November 2011 (Official Journal of 23 November 2011, L 306/41). Retrieved from https://eur-lex.europa.eu/legalcontent/EN/TXT/?qid=1590595266604\&uri=CELEX:32011L0085.

Decision № 18 of 16.12.1993 on c. case № 19/1993 of the Constitutional Court. Retrieved from http://www.constcourt.bg/bg/Acts/GetHtmlContent/ec92623d-e0c2-4158-9bb5ff1b72757250.

Decision of the Constitutional Court № 17/1995, promulgated SG, issue 93/1995. Retrieved from http://www.constcourt.bg/bg/Acts/GetHtmlContent/238ccffe-1fee-4f48-ba9b2295b99ad28f.

Decision of the Constitutional Court № 7/2005, promulgated SG, issue 52/2005. Retrieved from http://www.constcourt.bg/bg/Acts/GetHtmlContent/a98488a5-4632-4cb9-b47dc607e17db269.

Decision of the Constitutional Court № 8/2012, promulgated SG, issue 53/2012. Retrieved from http://www.constcourt.bg/bg/Acts/GetHtmlContent/499ed90a-0de7-4e16-a7d9e5e89e1208e5.

Decision of the Constitutional Court № 1/2020 (promulgated SG, issue 13/2020. Retrieved from http://www.constcourt.bg/bg/Acts/GetHtmlContent/ebac081c-20bc-431b-9cfa960f79ac6e7a.

Decision № 52 of the Council of Ministers of 31.01.2019 on the budget procedure for 2020 . Retrieved from https://www.minfin.bg/bg/1322. 
Definition of 3 December 1993 of the Constitutional Court (1993). Retrieved from http://www.constcourt.bg/bg/Cases/Details/176\#.

E-government Act of 2002. Retrieved from https://www.justice.gov/opcl/e-government-act2002; https://www.govinfo.gov/content/pkg/PLAW-107pub1347/pdf/PLAW107publ347.pdf.

Law on the Fiscal Council and Automatic Corrective Mechanisms (2015). Retrieved from https://www.minfin.bg/en/998?p=1

Law on the Normative Acts (1973). Retrieved from https://www.legislationline.org/download/id/8118/file/Bulgaria_law_normative_acts 1973 am2016_en.pdf.

Law on the State Budget of the Republic of Bulgaria for 1997. Retrieved from https://www.ciela.net/svobodna-zona-darjavenvestnik/document/2134141440/issue/256.

Municipal Budgets Act (1998). Retrieved from https://lex.bg/laws/ldoc/2134393857.

Organic Law of the French Republic from 01.08.2001 № 2001-692. Retrieved from http://europam.org/?module=legislation\&country=France.

Portuguese Constitution (1976). Retrieved from https://www.constituteproject.org/constitution/Portugal_2005.pdf.

Public Finance Act (2013). Retrieved from https://www.minfin.bg/en/998?p=1.

Rules of Organization and Procedure of the National Assembly (2017). Retrieved from https://www.parliament.bg/en/rulesoftheorganisations.

State Budget Procedures Act (1996). Retrieved from https://www.minfin.bg/en/998?p=1. 


\title{
COMPUTER TECHNOLOGY AND EHEALTH. TRENDS AND REGULATORY FRAMEWORK
}

\author{
ANDRIYANA ANDREEVA ${ }^{1}$ \\ GALINA YOLOVA ${ }^{2}$ \\ DIANA DIMITROVA ${ }^{3}$
}

\begin{abstract}
The paper aims to identify key aspects of the essence of eHealth (digital hospitals, clinical information systems, computerized medical records, telemedicine) as a priority European policy and how it is reflected in the national legislation of Bulgaria. In this sense, the aim of the study is first to highlight the typical European trends in the development of eHealth through continuous and well-established processes of application of digital technology to healthcare and their incorporation into the Community policies as a legal framework, and second to analyze national processes and stages of digitalization of healthcare and the health insurance system in terms of the creation of functioning and adequate eHealth. Based on the analysis performed, the authors have drawn conclusions about trends in and legal effects of the regulatory framework related to the efficiency of healthcare and the effective management of the health insurance systems.
\end{abstract}

Keywords: eHealth, digitalization of healthcare, National Health Strategy

JEL Codes: J81, K31

\section{Introduction}

The implementation of eHealth is a crucial step towards qualitatively different stages of healthcare and control of health insurance systems. Supported entirely by IT tools and processes, eHealth is expected to improve drastically the quality of and access to healthcare, including by overcoming the limits of the national systems.

The paper deals with the application of computer technology to modern healthcare. In this sense, the relevance of the subject is undisputable. On the one hand, this is due to the advent of digitalization in all spheres of public and private life. On the other hand, healthcare is among the most sensitive social issues and the State has the duty to ensure best quality care corresponding to modern trends. The interconnectedness of digitalization and healthcare is a concern not only of national institutions, but also of civil society. This issue has yet to be studied in its depth and complexity by legal scholars, and such studies would contribute to the clarification of a number of concepts and processes with a view to their proper legal regulation. The exploration of the issue in terms of its interdisciplinary aspects, namely its correlation to computer technology, presents a new perspective that could contribute to the proper practical interaction between healthcare stakeholders.

\footnotetext{
${ }^{1}$ Associate Professor PhD, University of Economics, Varna, a.andreeva@ue-varna.bg, ORCID iD https://orcid.org/0000-0001-6632-3695

${ }^{2}$ Associate Professor PhD, University of Economics, Varna, ina_yolova@ue-varna.bg, ORCID iD https://orcid.org/0000-0003-1976-3692

${ }^{3}$ Chief Assistant PhD, University of Economics, Varna, diandim@ue-varna.bg, ORCID iD https://orcid.org/0000-0001-5809-2612
}

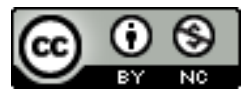

This work is licensed under a Creative Commons Attribution-NonCommercial 4.0 International License. 
In that sense, the objective of this paper is on the one hand to outline the typical European trends in the development of eHealth through continuous and well-established processes of application of digital technology to healthcare and their incorporation into the Community policies as a legal framework, and on the other hand to analyze national processes and stages of digitalization of healthcare and the health insurance system in terms of the creation of functioning and adequate eHealth.

In pursuance of this objective, the authors have undertaken the following tasks:

1. outline the general parameters of the nature and instruments of eHealth;

2. identify the main acts of European legislation, which constitute the sources of the process;

3. outline the stages of application of digital technology to the national legislation governing eHealth;

4. draw conclusions about the significance of and risks to the introduction of eHealth.

Methodologically, the paper employs the methods of legal research, namely the legislative method combined with the comparative method, for the purpose of comparing national with European norms.

The study complies with the legislation at European and national level existing as of 25 February 2020.

\section{EHealth on European level}

EHealth is a major European policy arising from the need to improve the access to treatment and the quality of healthcare and is associated with tools and services using information and communication technologies. It includes the design of systems for exchange of information and data between patients, healthcare providers, hospitals and professionals, and consists of health information networks, electronic health records, telemedicine services, portable equipment to monitor the condition of patients, software to determine the work schedule of operating rooms, etc. In practical terms, the development of eHealth involves processes and tools related to digital hospitals, clinical information systems, computerized health records, remote healthcare, telemedicine and mobile healthcare. In this sense, it not only implies and consists in data exchange within health information networks and integrated health records systems, but also opens completely different horizons in front of medicine by marching towards telemedicine services, robotic surgery and research and development in the field of the "Virtual Physiological Human".

The above goals of eHealth have been formulated at the level of the European Union as follows:

1. improve the health of patients by providing life-saving information even outside the boundaries of the state through eHealth tools,

2. improve the quality of and access to healthcare through the inclusion of eHealth in health policy and coordination between EU countries,

3. improve the efficiency, distribution and ease of use of eHealth tools by involving professionals and patients in the adoption and implementation of relevant health strategies as stated by the Commission (Overview of the aims, 2018).

The systematic development of eHealth as a Community policy is based on the strategy for a digital single market in Europe as a crucial step in achieving interoperability and adoption of standards for digital technologies in the EU. It includes the preparation and adoption of a number of instruments by European authorities, among which the most important are:

$\sqrt{ }$ A recent transnational regulation addresses the issue on cross-border interoperability of electronic health record systems (Commission Recommendation on cross-border interoperability of electronic health record systems, 2008). 
$\sqrt{ }$ Directive 2011/24/EU which provides for the establishment of a network of national authorities responsible for eHealth in order to optimize interoperability between electronic health systems and continuity of care and access to safe and quality health care.

$\sqrt{ }$ The issue is addressed also in Communication from the Commission to the European Parliament, the Council, the European Economic and Social Committee and the Committee of the Regions, eHealth Action Plan 2012-2020 - Innovative healthcare for the 21st century (Communication from the Commission to the European Parliament, the Council, the European Economic and Social Committee and the Committee of the Regions, eHealth Action Plan 20122020 - Innovative healthcare for the 21st century, 2012).

$\sqrt{ }$ Another transnational document is Communication from the Commission to the European Parliament, the Council, the European Economic and Social Committee and the Committee of the Regions on enabling the digital transformation of health and care in the Digital Single Market; empowering citizens and building a healthier society (Communication from the Commission to the European Parliament, the Council, the European Economic and Social Committee and the Committee of the Regions on enabling the digital transformation of health and care in the Digital Single Market; empowering citizens and building a healthier society, 2018).

$\sqrt{ }$ It is addressed also in Communication from the Commission to the European Parliament, the Council, the European Economic and Social Committee and the Committee of the Regions on telemedicine for the benefit of patients, healthcare systems and society (Communication from the Commission to the European Parliament, the Council, the European Economic and Social Committee and the Committee of the Regions on telemedicine for the benefit of patients, healthcare systems and society, 2008).

A number of European initiatives are related to the implementation of these acts, including the EU Measures to promote information and communication technologies in healthcare, and the associated Work Program for Standardization, Telemedicine (Tools to access information remotely), eTen - trans-European e-services of public interest (Database to search for projects in the field of eHealth) and others.

\section{EHealth at national level}

At the national level, in line with Community policies, the Bulgarian state has gradually and systematically adopted corresponding acts of legislation and strategic documents on the digitalization of healthcare. The underlying instrument is the National Health Strategy 2014-2020 (21.12.2013) which provides guidance for the development of eHealth systems for the purpose of "complete functional interoperability, according to European and national standards and a high level of information and network security." Based on this strategy, a Roadmap to the Development of eHealth was adopted in 2014. It seeks to develop and improve a software environment for information exchange, electronic health records, electronic registers, medical audits, electronic prescriptions, analysis capabilities, integrated identifier. This Roadmap indicates that the principal place in the design and further development of the eHealth system is occupied by the electronic medical record as a tool for coordination and provision of quality healthcare through the sharing of data by authorized persons, after obtaining the consent of the data subject.

In further development of the Strategy, the Program for Development of eHealth was adopted in 2014, which includes measures and actions to implement the main strategic objectives over the envisaged stages 1,2 and 3. The Council of Ministers proclaims in the Program that "the purpose of the project is to build a system with a set of electronic services electronic health records, electronic prescriptions, electronic referrals, electronic fit notes and others, which will exchange information and ensure transparency of the process of diagnosis and treatment of each patient, by ensuring access to all information online at any time" 
(Program for Development of eHealth, 2014). In the spirit of Community policies, the Council of Ministers stated in the Program that "the incorporation of healthcare processes into a single national system with the ability to control and exchange information in real time using modules for monitoring key indicators ensures interconnectedness of all processes through the applied innovative technology and allows for adequate analysis and intervention by the Ministry of Health." (Program for Development of eHealth, 2014). The Program identifies the main expectations from the introduction of the eHealth system, which can be analytically summarized as follows:

$\sqrt{ }$ reduce errors and duplication of medical activities and the administrative burden of the different procedures to the benefit of health care providers, patients and the system in general;

$\sqrt{ }$ improve the quality and efficiency of health services and thus the making of timely and adequate management decisions within the system;

$\sqrt{ }$ introduce uniform mechanisms for planning and forecasting of the processes in healthcare;

$\sqrt{ }$ increase transparency of medical and health insurance information and make possible its provision to all stakeholders.

The latest National Health Strategy 2020 and in particular Policy 2.6 "Development of eHealth" sets out the concrete stages of the introduction of eHealth, namely:

1. Adoption of national standards for health information and statistics and of policies on security and interoperability of information systems in healthcare.

2. Establishment of National Health Information System and ensuring public access to the system through an electronic identifier.

3. Expansion and upgrade of a modular health information system through real-time exchange of information among stakeholders in the health sector: electronic referrals, electronic prescriptions, laboratory data and research, electronic health records.

4. Introduction of information and communication technologies into the healthcare infrastructure by providing connectivity to all providers of medical services through computer networks, communication devices, Internet access.

5. Provision of hardware capability for centralized electronic registers and electronic databases, introduction of secure user authentication.

6. Development of web-based services operating in real time and tools to ensure information security through encrypted data exchange.

7. Design, refinement and implementation of a concept for the development of telemedicine in the various health sectors: emergency, outpatient and inpatient care, and in the process of provision of long-term care and integrated health services in the community and building a network of connections between them.

However, in analyzing the nature and effects of eHealth, we should not ignore the dangers to the legal framework, consisting in the inability to predict or even forestall the real threats to patients and providers through statutory and regulatory mechanisms. These risks can be summarized as follows:

$\sqrt{ }$ placing patients and medical services consumers under constant supervision, monitoring and surveillance, in view of the trend of increasing the role of prevention and its integration into the health service;

$\sqrt{ }$ the exchange of health information and its provision to different individuals and entities involved in the processes poses the very real threat of infringing unlawfully and unrecoverably upon personal civil rights; 
$\sqrt{ }$ possible impairment of fundamental ethical principles underlying the relationship between the physician and the patient, related to online professional practice, informed consent, privacy and equality (Galeva, Danova \& Grigorov, 2018);

$\sqrt{ }$ a shift in the healthcare values model and emergence of a real threat of it being commercialized. Thus, the European Economic and Social Committee proclaims with good reason that a functional eHealth system requires designing and implementing an "interoperability framework for health information systems", which unifies principles and standards for data exchange based on the five V's (Volume, Velocity, Variety, Veracity, Values) in order to prevent exploitation for purely commercial ends (Opinion of the European Economic and Social Committee on the "Impact of the digital healthcare revolution on health insurance", 2017).

\section{Conclusion and Recommendations}

EHealth is an inevitable consequence of the overall trend of digitalization of all public processes. On the one hand, the society is obviously undergoing processes, both at European and national level, related to the continuous adoption, updating and refinement of statutory and regulatory instruments aimed at creating a functional, harmonious, efficient and up-to-date healthcare system. At the same time, it is difficult to anticipate the appropriate mechanisms to safeguard the rights of individuals and to ensure privacy and personal data protection.

As rightly stated by the Council of Ministers in the National Scientific Program for eHealth, at the national level eHealth is facing a number of obstacles such as lack of interoperability between different software products and systems used by physicians and medical institutions; inadequately regulated protection of personal data; lack of transparency in the use of the collected data; voluminous medical records, which are prepared using software systems that require manual entry of a significant portion of the information (National Scientific Program for eHealth, 2018).

Healthcare is a conservative field, sensitive to changes. At the same time, it is subjected to the turbulent processes of digitalization and this requires the adaptation of the healthcare system to the new realities. It is undeniable that eHealth is the path to quality health services to the benefit of patients, given its ability to quickly and efficiently collect, analyze and archive data, resulting in better medical services, timely diagnosis and adequate treatment. But its successful implementation will take the concerted efforts of all stakeholders involved at the various levels of the process: government authorities implementing the policy, healthcare providers and computer experts, all seeking to create an operational, compatible and, above all, secure healthcare system. 


\section{References}

Council of Ministers, Ministry of Education and science. (2018). National Scientific Program for eHealth. Retrieved from: https://www.mon.bg/upload/15197/pr_nnp_e-zdrave100518.pdf.

Council of Ministry. (2014). Program for Development of eHealth. Retrieved from: http://www.strategy.bg/publicconsultations/View.aspx?lang=bg-BG\&Id=1510.

European Union, European Economic and Social Committee. (2017). Opinion of the European Economic and Social Committee on the 'Impact of the digital healthcare revolution on health insurance' (own-initiative opinion). (C434/1/15.12.2017).

Retrieved from: https://eur-lex.europa.eu/legalcontent/EN/TXT/PDF/?uri=CELEX:52017IE1370\&from=NL.

European Union, Commission. (2012). Communication from the Commission to the European Parliament, the Council, the European Economic and Social Committee and the Committee of the Regions eHealth Action Plan 2012-2020 - Innovative healthcare for the 21st century. Retrieved from: https://eur-lex.europa.eu/legalcontent/EN/ALL/?uri=CELEX:52012DC0736.

European Union, Commission. (2018). Communication from the Commission to the European Parliament, the Council, the European Economic and Social Committee and the Committee of the Regions on enabling the digital transformation of health and care in the Digital Single Market; empowering citizens and building a healthier society. Retrieved from: https://eur-lex.europa.eu/legalcontent/EN/TXT/?uri=COM\%3A2018\%3A233\%3AFIN.

European Union, Commission. (2008). Communication from the Commission to the European Parliament, the Council, the European Economic and Social Committee and the Committee of the Regions on telemedicine for the benefit of patients, healthcare systems and society. Retrieved from: https://eur-lex.europa.eu/legalcontent/EN/TXT/?uri=celex\%3A52008DC0689.

European Union, Commission. (2018). Overview of the aims. Retrieved from: https://ec.europa.eu/health/ehealth/home_bg.

European Union, The Commission of the European Communities. (2008). Commission Recommendation of 2 July 2008 on cross-border interoperability of electronic health record systems (notified under document number. (C(2008) 3282) L190/37/18.7.2008). Retrieved from: https://eur-lex.europa.eu/legalcontent/EN/ALL/?uri=CELEX\%3A32008H0594.

Galeva, Sv., Danova, N. \& Grigorov, Ev. (2018). Elektronizatsiya na zdraveopazvaneto v Balgariya, Godishnik po bolnichna farmatsiya, Sofia, 4 (1), 26. 


\section{THE ENTERPRISE MEMORY IN KNOWLEDGE MANAGEMENT OF MODERN ORGANIZATION}

\section{LARISA SHEMYATIKHINA ${ }^{1}$}

\section{Abstract}

The article considers the corporate memory of the organization as a modern management tool. Intuitive management of a modern organization comes to a new basic competence and the main competitive advantage of business in conditions of innovation and crises - knowledge management. Corporate memory of a modern organization as a structural element of knowledge management allows to increase efficiency of use of the experience of the organization itself, to ensure transition of corporate knowledge when changing generations of managers and employees of the organization, to reduce costs of access to sources of information.

Keywords: knowledge management, corporate memory, effects of forming and using corporate memory

JEL Codes: M10, M14, M21

\section{Introduction}

The viability of a business is tested by its sustainability under the influence of many negative factors that limit development.

The industrial revolution over the past two centuries has defined the rules of doing and developing business. In the conditions of social and economic crises, the principles of business management that have become commonplace are being leveled off and new ones are emerging. Business in the early XXI century is characterized by bureaucracy, organizational fragmentation and impersonality. Managers of all levels and employees themselves are involved in a continuous cycle of routine mechanical activity. Competitive advantages were gained by types of business whose personnel were involved in the processes of managing the organization, analyzing opportunities and planning strategic priorities.

Management technologies and communications, which demonstrated efficiency during the period of industrialization, began to hinder the transformation of the organizational structure and business culture. Intuitively, management comes to a new core competence and the main competitive advantage of business in an innovative environment - knowledge management.

Knowledge management as a business philosophy should form a "portfolio" of new intelligent management technologies that allow decisions to be made in difficult economic conditions.

\section{Review of literature}

Drucker believed that "knowledge has become a key economic resource and the dominant, if not the only source of competitive advantage" (Drucker, 2004, p. 272).

\footnotetext{
${ }^{1}$ Assoc. Prof. Larisa Shemyatikhina, PhD, The Ural State Economic University, 1yshem@mail.ru ORCID ID https://orcid.org/0000-0002-2717-9018
}

\section{(ब) $(\Theta$}

This work is licensed under a Creative Commons Attribution-NonCommercial 4.0 International License. 
From the author's point of view, knowledge management is a methodology for the acquisition, accumulation and development of corporate knowledge and experience, which are an integral part of the market value of a modern organization. Knowledge management as a management philosophy was recognized in Russian science and management practice in the mid-1990s, but has not yet become widely accepted. The world budget of knowledge management systems at the beginning of the 21 st century was already estimated at $\$ 2$ billion and is still growing (Gavrilova \& Muromtsev, 2008, p. 488).

Updating of knowledge management took place at the time when the Coronavirus pandemic was declared. It turned out that the world infectious threat and its course, in contrast to economic phenomena, is not amenable to economic and mathematical modeling and expert analysis of intellectual systems. Management, which introduces an economy based on knowledge and management into organizational practice, builds a business strategy that allows increasing the speed and efficiency of reaction, transformation of business forms to changes in the business environment by influencing the most valuable corporate resources - collective know-how and competence of personnel.

Knowledge management does not shift to a policy model of management, the focus of management attention shifts to the creation of a corporate culture that should encourage knowledge sharing and creative thinking of staff. The key asset of the organization - core competence and intellectual capital - is being reassessed.

At the heart of industrialization is reengineering, which can offer a temporary solution to the problem, adapting the basic product of the organization to the market. At the heart of reengineering lies a provision that the investigated market conditions remain invariable, and in the former corporate memory the outdated information on external conditions, goods, processes remains. During the reengineering process, databases and marketing technologies are actively developed, the purpose of which is to promote the organization's basic product in the market. The reengineering activities repeated by the organization in the conditions of social and economic crises are burdened with irrelevant corporate memory. It is obvious to managers analysts that the solution of the situation is in the competence of knowledge management.

There is now considerable interest in knowledge management from commercial and industrial companies, which have begun to realize the high application potential of corporate memory for a range of information processing applications, and to invest in research in this area.

Reasons for addressing the knowledge management philosophy:

- organization personnel spend a large amount of time meeting information needs;

- experience of leading and most qualified specialists is not distributed systemically in the organization and is used only by them;

- valuable information is "buried" in a large number of documents and data, access to which is limited and difficult;

- costly mistakes are repeated due to lack of awareness and disregard of lessons learned, and subjective position of management.

The novelty of the philosophy of Knowledge Management (CM) lies in the fundamentally opposite task - to save not disparate information, but knowledge, i.e. patterns and principles that allow to solve production and business tasks.

Existing methods of knowledge management ignore knowledge engineering and methods of work with knowledge, propagandizing economic scheme of life cycle, in particular (Bukovich \& Williams, 2002, p. 504; Nonaka \& Takeuchi, 2011). 


\section{Methodology}

It can be assumed that by combining an economic approach with knowledge engineering regulations, knowledge management is a process involving steps:

1 - diagnosis of the need of the organization as an economic system in knowledge and its volume and available access to the accumulated experience and knowledge of the system itself and beyond (documents, data, knowledge);

2 - knowledge acquisition, including extracting and structuring;

3 - distribution of knowledge among personnel in various forms (content), including corporate training, and implementation of core competencies;

4 - use, including collaboration to supplement knowledge, relevance assessment, archiving and support (repositories), liquidation.

Features of knowledge management, in comparison with information flow management, is that it depends not on the amount of accumulated information, but on the branching of the network that provides staff access to available corporate memory. The structure of corporate memory should be at a level depending on the needs of the subject participating in decision-making: the level of explicit information and the level of hidden (implicit) information.

Knowledge management focuses on providing personnel with access to corporate memory - information through the value chain of special procedures. The "knowledge chain is formed by four links" (Koulopoulos \& Frappaolo, 2008, p. 224), which determine the ability of the organization to innovate and be effective and which management should design:

1) internal awareness - the ability of the organization to quickly access experience and core competencies, and to abandon the functional organizational structure;

2) internal response - the integrativeness and speed of transformation of the core competence to opportunities and emerging threats;

3) external reaction - ability of the organization to develop strategies with a wide range of goals and tactical methods of response to competitors' actions;

4) external awareness - the ability of the organization to design and implement new business models as a response to consumer behavior taking into account market trends, competitors' actions, government regulation and other factors affecting the organization in its external environment.

Corporate memory is a process of analyzing data, identifying hidden patterns and causal relationships using an economic and mathematical apparatus, methods of encoding information and software.

Let 's highlight basic knowledge strategies for building enterprise memory:

- strategies based on secondary information are needed in the absence of experience within the organization itself, especially at the beginning of the life cycle: learning when many business examples are the source of knowledge; Acquisition of knowledge using appropriate software tools or texts of specialized literature;

- the strategy based on primary information when the organization itself begins to integrate knowledge: formation of knowledge with use of programs of corporate training in the presence of representative selection of own examples by types of economic activity and the functional fields of management, and the appropriate application programs; Knowledge extraction - without the use of software tools through direct contact of leading specialists with the personnel of the organization.

The method of structuring the knowledge of corporate memory is also updated. In the classical sense, they are subdivided into visual (hierarchical, network, linear, graphic) and symbolic (table and text). Symbolic methods are recommended in organizations where the subject area is well structured, visual methods in less formalized and creative activities. 


\section{Results and discussion}

In the formation of corporate memory, the following questions will be answered for stratification of knowledge of the subject area of the organization:

The purpose and functions of the economic system;

Who? - developers and users of corporate memory;

What are the main components of the activity and its conceptual (categorical) structure; How? - hypotheses and models of making management decisions;

Where? - space of corporate memory usage (environment, equipment, communications);

When? - time of accumulation and period of information relevance (time parameters and restrictions on use); transfer;

Why? - causal relationships between information modules and channels of knowledge payback).

How much? - is the economics of corporate memory (resources, costs, profits,

As the simplest application approach to building corporate memory, organizations beginning to apply a philosophy of knowledge management can suggest the following algorithm:

1 - definition of input and output data (what documents and knowledge are needed for activity in the subject area);

2 - preparation of a dictionary of terms and sets of keywords (terminology of processes and operational activities);

3 - identification of objects and concepts on functional areas of responsibility of management and personnel;

4 - identification of links between objects and concepts (causal links of subordination and co-submission);

5 - identification of meta-concepts and detail of concepts (area of key competence of the organization);

6 - construction of "pyramid" of knowledge with definition of information needs by hierarchy of management;

7 - definition of relations as a zone of coordination of information fields and influence on decision making;

8 - definition of management decision-making strategy.

Corporate memory management forms can take a variety of positions and responsibilities, ranging from a knowledge manager with no specific place in the organizational structure or structural unit for strategic management. Systematization of positions and duties is a competence of the organization, it is possible to mark out categories of management of knowledge only: the managing director of knowledge - the manager on management of knowledge - the analyst of management of knowledge - the technologist (engineer) of management of knowledge.

Effects of formation and use of corporate memory, first of all, will be manifested "at" and "from" corporate training of personnel.

When budgeting the costs of corporate training of personnel, it is necessary to take into account that they are the largest item of expenditure after wages. According to the accounts of large organizations, they spend from 2 to $10 \%$ of the wage fund (or from 2.5 to $11 \%$ of the profit) on training, but in the context of socio-economic crises these volumes significantly decrease. This will mean losing competitive positions and "rolling back" to the path already 
travelled. Corporate memory is a constant source of experience and knowledge that has already been paid for and does not require additional costs.

\section{Conclusion}

Using corporate memory offers a fundamentally new approach to learning for those managers who value their time. Today, even the most qualified work on the team inefficiently because of the availability of behavioral patterns that have been successfully used in the past, and do not understand how far they lag behind in new, rapidly changing environments. The corporate memory of the organization will not allow to "forget" about its key competence in the business community and society, will allow to analyze the events, form adequate attitude and patterns of behavior, promptly and constructively change the order established in the organization.

Thus, knowledge management allows any economic system to form corporate memory and make it actual and accessible to the decision of commercial and industrial, financial problems, providing stability and development in the most difficult conditions of activity. 


\section{Reference}

Bukovich, W., \& Williams, R. (2002). Knowledge management: a guide to action. [Upravlinnya znannyamy. Kerivnyctvo do dii.], Moskva: INFRA-M.

Drucker, P. (2004). Challenges of Management in the 21st Century [Translate with English], Moscow: Williams.

Gavrilova, T. A., \& Muromtsev, D. I. (2008). Intelligent technologies in management: tools and systems, Saint-Petersburg: Graduate School of Management.

Koulopoulos, T. M., \& Frappaolo, T. M. (2008). Upravlenie znaniyami [Knowledge management], Moskva: Eksmo.

Nonaka, I., \& Takeuchi, H. (2011). Company-creator of knowledge. Origin and development of innovation in Japanese firms, M.: Publisher Olympus-Business. 


\title{
CHALLENGES AND OPPORTUNITIES FOR SOCIAL ENTERPRISES
}

\author{
MARIELA BOGDANOVA ${ }^{1}$
}

\begin{abstract}
The current topic focuses on the new social vision and challenges after the adoption of legislation on the social and solidarity economy in Bulgaria, as well as on the opportunities for access to financing and institutional support for social enterprises.

The progress made is seen in a broader perspective, including not only statistics on the number of social enterprises self-identified, but also proven social added value and entered in the Register of social enterprises. Tracking the challenges is in the context of the process and the employment and human resources options and the provision of a supportive environment for the sustainable development of social enterprises. Although 2019 has emerged as a strong startup community, we still don't have startups for social entrepreneurship. This, of course, does not mean that Bulgaria lacks successful models of social enterprises that provide employment for persons from different vulnerable groups and answer questions related to the social impact and benefits of applying the principles of the social economy. The European Union today, more than ever, emphasizes its new social vision, based on opportunity and solidarity.
\end{abstract}

Keywords: new social vision, social enterprises, law-making, social added value

JEL Codes: $B 55$

\section{Introduction}

The validation process of the new social vision and of the institutional support provided by the social enterprises continues to have a significant meaning with a view of the perspective for the development of the social economy as a fraction of the whole concept for EU solidarity, including crisis periods. It is possible to provide concern for the labor group as part of achieving the proposed targets in the Europe 2020 smart and inclusive strategy is also based on breaking up some European citizens for a more social dimension to assessing existing work, consumption and investment. Taking into account the prospects for the social economic development in Bulgaria, over the transfer of basic statistics on the number of social enterprises represented within this framework, which can be defined as such.

Today's opportunities aim to provide an adequate response to many challenges. This includes legal framework, financial resources and measurability of the social added value of a product or service produced by social enterprises. In the context of the consensus reached with regard to social enterprises, the sustainability of trends contributing to their increasing visibility and increasing social impact is observed, including by providing incentives for businesses in the real sector to participate in the social economy. It is the unification of all elements in a single integrated process that leads to the consolidation of the new social vision of enterprises,

1 PhD Student "Faculty of Economics", South-West University "Neofit Rilski”, Blagoevgrad, Bulgaria, bgregioni.ltd@gmail.com ORCID iD https://orcid.org/0000-0002-9881-3485

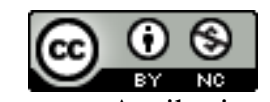

This work is licensed under a Creative Commons Attribution-NonCommercial 4.0 International License. 
including a set of measures (economic and institutional tools) to support the processes of overcoming and new social challenges.

\section{Legislation and social economy}

There are numerous initiatives and regulations at EU level aimed at developing the social economy and social enterprises. Until 2018 in Bulgaria, the social economy had no legal regulation, but nevertheless, such forms could be found in practice. The definitions reflected in a number of EU documents were used to define social economy entities. This also led to various difficulties, which were mainly related to the sustainable development of social enterprises, a fragmented legal framework (social service providers, specialized enterprises, etc.), provision of a supportive environment for the development of social enterprises, and regulation of specific requirements, including opportunities for tax relief for economic operators, including uncertainties regarding the measurability of the performance of their business.

The regulation of the social economy at the law level was regulated after the adoption of the Law on Enterprises of the Social and Solidarity Economy (2018). Until now, the social economy has been supported mainly by the National Concept for Social Economy (2012), as an expression of the political commitment of the state institutions of the Republic of Bulgaria to create a favorable environment for the development of models and practices for the social economy. It is through the Concept that the anticipatory vision of the future changes in the regulation and practice of the state bodies is ensured, as well as the vision regarding the integration of sectoral policies. In order to clarify the differences in the laws of the European countries, the characteristic of social enterprises given by the European research network EMES (https://ec.europa.eu/info/research-and-innovation/strategy/era_en) was also used. EMES criteria are connected to the entrepreneurial and social dimensions.

\section{Table 1. Social enterprise legislation in some European countries compared to EMES criteria}

\begin{tabular}{|c|c|c|c|c|c|}
\hline $\begin{array}{l}\text { EMES criteria } \\
\text { (www.emes.net) }\end{array}$ & $\begin{array}{l}\text { Community } \\
\text { Interest } \\
\text { Company } \\
\text { CIC UK }\end{array}$ & $\begin{array}{l}\text { Italian } \\
\text { law on } \\
\text { Social } \\
\text { Co-ops }\end{array}$ & $\begin{array}{l}\text { Belgium } \\
\text { Social } \\
\text { purpose } \\
\text { companies }\end{array}$ & $\begin{array}{l}\text { Portugal } \\
\text { Integration. } \\
\text { Companies }\end{array}$ & $\begin{array}{l}\text { Finnish Act } \\
\text { on Social } \\
\text { Enterprises. }\end{array}$ \\
\hline $\begin{array}{l}\text { Continuous production of goods and/or } \\
\text { services }\end{array}$ & & $\mathrm{x}$ & $\mathrm{x}$ & $\mathrm{x}$ & $\mathrm{x}$ \\
\hline A high degree of autonomy & & $\mathrm{x}$ & & $\mathrm{x}$ & \\
\hline A significant level of economic risk & $\mathrm{x}$ & $\mathrm{x}$ & $\mathrm{x}$ & $\mathrm{x}$ & $\mathrm{x}$ \\
\hline A minimum amount of paid work & & $\mathrm{x}$ & $\mathrm{x}$ & $\mathrm{x}$ & $\mathrm{x}$ \\
\hline $\begin{array}{l}\text { A initiative launched by a group of } \\
\text { citizens }\end{array}$ & $\mathrm{x}$ & $\mathrm{x}$ & & $\mathrm{x}$ & \\
\hline decision-making power not based on & & $\mathrm{x}$ & $\mathrm{x}$ & $\mathrm{x}$ & \\
\hline $\begin{array}{l}\text { capital ownership } \\
\text { A participatory nature, which }\end{array}$ & $\mathrm{x}$ & $\mathrm{x}$ & $\mathrm{x}$ & & \\
\hline $\begin{array}{l}\text { involves the persons affected by the } \\
\text { activity }\end{array}$ & $\mathrm{x}$ & $\mathrm{x}$ & $\mathrm{x}$ & $\mathrm{x}$ & \\
\hline $\begin{array}{l}\text { Limited distribution of profits } \\
\text { An explicit aim to benefit the } \\
\text { community }\end{array}$ & $\mathrm{x}$ & $\mathrm{x}$ & $\mathrm{x}$ & $\mathrm{x}$ & $\begin{array}{c}\mathrm{X} \\
\text { (employment) }\end{array}$ \\
\hline
\end{tabular}

Source: Pättiniemi Pekka, 2008 
The following presentation of the Law on Social and Solidarity Economic Development in Bulgaria is about public relations, by contacting the social economy you are sure that you have chosen to evaluate and edit for social enterprises. The law clearly defines the social economy as a form of entrepreneurship aimed at one or more social activities and / or social goals pursued by enterprises, including through the production of various goods or the provision of services, in cooperation with state or local authorities or independently. The legitimated legal framework has identified the social economy entities, including vulnerable groups, which leads to involving them in employment that meets the organizational requirements.

Thus the main challenge to the development of the social economy in Bulgaria was achieved, but the subjects of the social economy (social enterprises) were challenged to fulfill the legal requirements under the terms and procedures set by the Rules for the implementation of the Law on Enterprises of the Social and Solidarity Economy (2019). All these legal acts help people with disabilities to have a chance for inclusion in the labor market, this "is crucial for the development of the social insertion activities for people with disabilities" (Atanasova, Krastev, Parvanov \& Todorov, 2019, p. 67). The new element is related to proving the social added value produced by their activities. In order to clearly regulate the definition of social added value, a methodology was developed to evaluate the social impact of the activities of social enterprises. The Methodology for assessing the social added value produced by the activity of the social enterprises under Art. 7 and Art. 8 of LESSE also determines the assessment intervals: up to 8 points, social enterprises have no social added value and social added value is demonstrated at 9 points or more. Determining the presence or absence of social added value is a requirement under the Law on Enterprises of the Social and Solidarity Economy.

The economic impact of the activities of social enterprises (organizations) is also an expression of their flexibility and ability to mobilize resources of different origins - market and non-market resources, volunteer work and broad public support. This contributes to maintaining the trend of steady increase and civic initiatives realized through the opportunities provided by funding under the Operational program "Human Resources Development" (20142020) with a focus on developing the social economy. This contributes to a positive and stable development of organizations that work in the social sector. Kicheva (2017) reveals that there is a remarkable growth of the social economy, with the ever-expanding spheres of activity of the so-called organizations, social or public goods, mainly labor and social integration, as well as social services and home patronage. To ensure greater public awareness and as a means of interaction between the subjects of the social economy, institutions and civil society, a functioning electronic register of social enterprises was established on the territory of the Republic of Bulgaria. Its main aim is to identify enterprises in the field of social economy and to provide information on the defined indicators for social enterprises, their distribution in the country, areas of activity, class, etc. Social enterprises (by district) to m. April 2020 are presented in Table 2.

Table no. 2 - Social enterprises (by districts), April 2020

\begin{tabular}{|l|l|l|l|}
\hline By District & $\begin{array}{c}\text { Status: Active social } \\
\text { enterprise }\end{array}$ & $\begin{array}{l}\text { Status: Waiting } \\
\text { for verification }\end{array}$ & Class \\
\hline Blagoevgrad Region & 3 & 1 & A \\
\hline Varna Region & 1 & 2 & A \\
\hline
\end{tabular}




\begin{tabular}{|l|l|l|l|}
\hline Vratsa Region & 1 & - & $\mathrm{A}+$ \\
\hline Kardzhali Region & - & 1 & $\mathrm{~A}$ \\
\hline Kyustendil Region & - & 1 & $\mathrm{~A}$ \\
\hline Lovech Region & - & 2 & $\mathrm{~A}$ \\
\hline Pazardzhik Region & 1 & - & $\mathrm{A}$ \\
\hline Plovdiv Region & - & 1 & $\mathrm{~A}$ \\
\hline Ruse Region & - & 1 & $\mathrm{~A}$ \\
\hline Silistra Region & - & 2 & $\mathrm{~A}$ \\
\hline Smolyan Region & - & 1 & $\mathrm{~A}+$ \\
\hline Sofia Region & - & 1 & $\mathrm{~A}$ \\
\hline Sofia Region(capital) & 2 & 5 & $\mathrm{~A} / \mathrm{A}+$ \\
\hline Stara Zagora Region & - & 1 & $\mathrm{~A}$ \\
\hline
\end{tabular}

Source: Register social enterprises

According to the public data in the register, social enterprises operate throughout the country, the largest being in the territory of Sofia District (capital), with the registered social enterprises being both Class A and Class A +. Entry in the Register is also a condition for funding under the Operational Program "Human Resources Development". Registered social enterprises are also entitled to use the certification mark of social enterprise products. The purpose of the certification mark is to raise the awareness of the stakeholders about nature, functioning of the social economy and the development of an active, supportive environment for the subjects of the social economy.

\section{A supportive environment for social economy subjects}

The creation of social enterprises, including in areas such as the creative industries, is a possible way to provide an appropriate supportive environment that reduces the negative impacts. Positioned in a specific business niche, new social entrepreneurs can combine the creativity with economic benefits in a unique way. In Study on the economy of culture in Europe (2006), EU researches indicate that the cultural and creative industries have great potential for development and are among the dynamic sectors contributing about $2.6 \%$ of EU GDP. According to the Towards an EU Strategy for International Cultural Relations (2016) the sector is becoming an engine for economic growth not only in its traditional forms but also in particular through the cultural and creative industries, SMEs and tourism. Moreover, in Council conclusions on the contribution of the cultural and creative sectors to the Lisbon objectives (2007) the culture and creativity are important economic resources, and as the link between education and industries is strengthened, the potential of SMEs is maximized. New forms of solidarity, social commitment and civic participation are emerging, increasingly involving the use of new technologies in cultural activities (digitalization of cultural heritage, virtual museums, etc. The Employment and Social Innovation Program (EaSI) (https://ec.europa.eu/social/main.jsp?catId=1081\&langId=en) draws attention to taking into account the territorial dimensions of unemployment, poverty and social exclusion, as well as the inequalities that exist between regions and within them, between rural and urban areas, as well as within the cities themselves. Considering the perspectives and benefits of the social economy, it should be noted that social enterprises cannot provide universal solutions to problems, and the main challenge remains, to demonstrate their ability to be an equal partner 
in solving important social problems and to prove that innovation and flexibility are their main distinguishing features. The tuition of young social entrepreneurs, including in fields such as the creative industries, is a possible way of providing the right supportive environment. Providing a sustainable, supportive environment for the social economy, it will continue to provide benefits related to increasing the social impact of public savings on social benefits and offsetting the social cost of long-term employment/unemployment. It is crucial to note that long-term unemployment is not a wish, but due to a lack of suitable jobs or a lack of awareness of existing opportunities. People aged 50-54 are often left permanently unemployed, and staying out of the job market also reduces their chances of getting a job. The problem of unemployment among older workers is a phenomenon in the labor market not only in our country but also in the other EU Member States. It is much more challenging to return to work if you are in this group, as many employers find that this group is less adaptable to change. From this point of view, they are often rejected even in preliminary selections. This further discourages these individuals and puts them at risk of social exclusion. Overcoming these and

other challenges is at the heart of the growing interest in social enterprises that the new social economy can do in human society.

\section{Conclusion}

The essence of every social enterprise is in its economic activity with a pronounced social effect. Despite all the steps taken so far, there remains a need for a more focused policy to support social enterprises as a tool for social inclusion and labor integration, including for disadvantaged people. 


\section{References}

Atanasova, I., Krastev, V., Parvanov, P., \& Todorov, I. (2019). European Union Legislation for encouraging the Social Entrepreneurship for people with disabilities. Economics \& Law, 1(2), 59-69.

Directorate General for Education and Culture. (2006). Study on the economy of culture in Europe. Retrieved from https://ec.europa.eu/assets/eac/culture/library/studies/cultural-economy_en.pdf

European Union. (2013). Programme for Employment and Social Innovation (EaSI). Retrieved from https://ec.europa.eu/social/main.jsp?catId=1081\&langId=en

European Union, European Commission. (2010). Europe 2020 A strategy for smart, sustainable and inclusive growth. Retrieved from http://publications.europa.eu/resource/cellar/6a915e39-0aab-491c-8881147ec91fe88a.0004.02/DOC_1

European research network (EMES). Retrieved from https://ec.europa.eu/info/research-andinnovation/strategy/era_en

European Union, Council of the European Union. (2007). Council conclusions of 24 May 2007 on the contribution of the cultural and creative sectors to the achievement of the Lisbon objectives. Retrieved from https://op.europa.eu/en/publication-detail//publication/a80e5812-9864-4817-8ff5-37ae5d65935a/language-en

European Union, European Social Fund. Human resources development operational programme 2014-2020. Retrieved from http://ophrd.government.bg/view_file.php/21022

European Union, Report of the EU Commission. (2016). Towards an EU strategy for international cultural relations. (2016/2240(INI)). Retrieved from https://www.europarl.europa.eu/doceo/document/A-8-2017-0220_EN.html

Kicheva, M. (2017). Social economy - past and present. The social economy in conditions of limited resources - theory and practice (pp. 60-62). Blagoevgrad

Law on Enterprises of Social and Solidarity Economy. (2018). Retrieved from https://www.lex.bg/bg/laws/ldoc/2137187968

Ministry of labor and social policy. (2012). National Concept for Social Economy. Retrieved from http://seconomy.mlsp.government.bg/page.php?c=1\&d=54

Ministry of labor and social policy. (2019). Methodology for assessing the social added value produced by the activity of the social enterprises under Art. 7 and Art. 8 of LESSE.

Retrieved from http://seconomy.mlsp.government.bg/upload/docs/201905//METHODOLOGY.pdf

Pättiniemi, P. (2008). Social Enterprise Legislation in Finland. Retrieved from http://seconomy.mlsp.government.bg/upload/docs/201112/Finland_Soc_ent_Radi_F.pdf

Register social enterprises https://secprod.mlsp.government.bg/index.php?section=REG\&lng=_eng 
Rules for the implementation of the Law on Enterprises of the Social and Solidarity Economy (DCM № 115/13.05.2019). Retrieved from

https://www.lex.bg/bg/laws/ldoc/2137193136 


\title{
STRATEGIES AND POLICIES WITHIN THE CONTEXT OF SUSTAINABLE DEVELOPMENT OF INDUSTRIAL ENTERPRISES
}

\author{
Gergana Yocheva ${ }^{1}$
}

\begin{abstract}
The contemporary understanding of development of enterprises of industrial sector is particularly associated with their need to be sustainable. This article presents the essence and varieties of a sustainable development of enterprises, as with regard to them, the main task is to achieve sustainability of economic development. The objective of this article is to show the relation between the strategies and policies of sustainable development, as nowadays, in the modern dynamic world, they are in a direct relation. The efforts of industrial enterprises should be aimed at the establishment of prerequisites for their successful creation, growth and development, in order to become sustainable economic entities.
\end{abstract}

Keywords: strategies, policies, sustainable development, industry

JEL Codes: L160, O200, O210, O250

\section{Introduction}

In the course of the recent ten years there have occurred deep changes in the development, organisation and competitiveness of the enterprises of the industrial sector. They are all of a different nature and have different methods and approaches. The changes are predetermined by the fact that the enterprises needed to overcome and handle the unfavourable consequences of the constant economic crises, which the country has been facing all that time. The goal is to achieve economic growth and sustainable development in period of incessant fight for survival and prosperity, as well as for providing the individual with the necessary means of living, income and increase of life standard.

The objective of this article is to analyse the strategies adopted by the industrial enterprises and used by them to achieve sustainable development, the policies implemented to achieve growth and expansion of production through innovations and innovative activities. Enterprises in Bulgaria have to continuously look for alternative ways for development and attainment of goals, and the development and success of an industry depend on corporate culture, managing staff, work environment and most of all, on the employees involved in the production process. That, on its part, brings to stability and competiveness of industrial enterprises.

\section{Characteristics of the strategies and policies within the context of sustainable development of industrial enterprises}

The strategic management and marketing approach are of a fundamental significance in the nowadays situation, as huge changes are occurring in the structural and branch characteristics. The transformations observed happening as a result from the development of

${ }^{1} \mathrm{PhD}$ Student, Department of "Management and Marketing", "Faculty of Economics", South-West University "Neofit Rilski”, Blagoevgrad, Bulgaria, geryiocheva@abv.bg

ORCID ID https://orcid.org/0000-0001-7828-5665

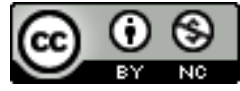

This work is licensed under a Creative Commons Attribution-NonCommercial 4.0 International License. 
the current crisis are firm and significantly important stress circumstances for Bulgarian industrial enterprises and their competitiveness (Ilieva, 2011 p. 166).

For preparing their policy and strategy of planning, industrial enterprises use various methods and approaches, and by applying the appropriate strategies, they ensure the success in developing and planning their business. Strategic planning is one of the main tools for the successful management of an enterprise. The industrial enterprises make business in a situation of incessant changes of market economy, placing certain requirements to their strategic management (Nikolova, 2005, p. 395). The activity bringing to success for the enterprises may be defined as an entire set of actions aimed at the efficient use of resources for the achievement of the goals while taking into consideration the criteria of expedience and social justice. Strategic goals define a particular measurable state of business and position it into the market environment in compliance with the criteria of sustainable development (Ivanova, 2010, p. 100).

The expedient influence on the development of industrial enterprises through elaborating and implementing strategies, policies and programmes is a complex and difficult process (Vladimirova, 2007, p. 182). This is so because of the character and object of influence, as well as the interactions of the enterprises with the development of economy, society, and resources. Economic sustainability is a fundamental systematic branch of sustainable development, and it provides actual opportunities for the creation of an economic value form the available resources, and this way the quality of life of every man is improved (Ivanova, 2010, p. 97). The strategy of enterprises should be aimed at the optimum, purposeful and intelligent use of resources, including provisions for achieving the forecasted profits, as well as their increase and maximisation, and eventually, the achievement of high efficiency of business.

The main factors determining the sustainability of development of an industrial enterprise are human and natural resources, as well as production technologies. The said three factors are in a continuous interaction with the others, while each factor is submitted to its own regularities and functions independently (Kindzhakova, Krachunov, 2015, p. 55). The sustainable development in its essence unites two intentions of society based on the achievement of economic development, ensuring a rising standard of living and a long-term protection and improvement of environment (Kirilov, 2018, pp. 17-18), it also meets to the fullest the needs of population without damaging the options for satisfying the needs of the coming generations.

\section{Analysis and discussion of the strategies and policies within the context of sustainable development of industrial enterprises}

The outlooks to the development of the enterprises in Bulgaria show need for strengthening the management spirit and fostering the development of business, as their competitiveness is not strong. The situation in the sector is due to the fact that the organisation of entrepreneurship in the country is not sufficiently good. The policies, as shown in the Research of entrepreneurship and outlooks to the development of innovations in SME (2013), within the context of development and situation of growth are of a strategic significance both for Europe 2020 Strategy and for "Bulgaria 2020" National Development Programme.

The effects of the management strategy are explained within the broad sense of the concept and can be found in two different directions, on the one hand, they occur as a result from a good management activity, and on the other hand, the effects result from applying by the part of the company of examples of good corporate culture and good management practices (Ilieva, 2011 p. 167). 
A successful sustainable development strategy of an industrial enterprise results from the spread of the free business initiative that stimulates its existence and manifestation (Madgerova, 2004, p. 8-13). The measures to be initiated by the part of the state to that regard cover stimulation of a macroeconomic policy affecting the business environment, differentiated impact of governmental acts on the companies of various sizes, influence on the public opinion regarding the significance of entrepreneurship and entrepreneur initiative, and recognition for and integration of the small and medium enterprises in the policy of industrial enterprises (Smallbone, 1995, pp. 8-13).

For an industrial enterprise to achieve sustainability it is important how it is managed by the business entrepreneur (Schore, 2010, p. 146). But with regard to that, the adaptation to sustainable practices is restricted not so much by technical novelties, but rather by the incapability of the owners of industrial enterprises to change the outdated predispositions and cultural norms (Anderson, Amodeo, Herzfeld, 2010, p. 153).

The methodology of the enterprises strategy requires purposeful changes in the structure of management, in the strategies for business development, in the communications of the enterprises (Filipova, 2016, p. 221). Such a significance requires continuous purposeful management actions to be aimed at the optimisation of work environment and development and implementation of efficient innovation strategies that are adequate to the dynamic changes (Kyurova, 2015, p. 204).

According to the Ministry of Finance (2019, p. 104), the main obstacles to the fast growing development of the sector are the poor innovation activity, the deficit of qualified staff and entrepreneur's skills, and last but not least, the low level of internationalisation of business. The development of enterprises in the situation of the modern market economy is largely influenced by competition. For a large part of them it is difficult to survive in the sector of industry. Most of them have to do with the growing share of grey economy, which worsens the situation mainly through non-payment of taxes and non-compliance with some of the standards within the country, which has its impact on the fair producers, and this way hampers the growth of the production capacities of the sector (Patarchanov, 2016, pp. 162-163).

For a strategy to be innovative, competitive and to have a good position for handling the challenges to society, it needs appropriate framework terms, as shown in Industry in Europe, facts and numbers regarding competitiveness of innovations (European Commission, 2017). The main goal of the individual business entrepreneur is to establish the required position in the industry in order to get protected in all the possible ways against the competitive parties and at the same time, to have his own impact in his favour (Porter, 2010, pp. 4-50).

Based on how a social and economic system functions, competition can be characterised, covering also the competitive relations (Mishev, 2011, p. 21). This is an assessment of the development of potential of the countries for the achievement of high productivity, though implementing an innovative approach, which means a higher economic growth and manner for overcoming the competitive pressure. Competitiveness, in general, is defined by many factors: macroeconomic stability, openness of economy, efficient management and good legal framework (Toncheva, 2013, p. 29).

For the achievement of a sustainable development, an important role is played by the use of new management technologies related to the efficiency of administration of industrial enterprises, at which a need for the theoretical substantiation of "efficiency of management" occurs (Milcheva, 2012, p. 1-2). It is necessary to explore, research and analyse the approaches, criteria, indicators for assessing efficiency of management of industrial enterprises by characterising productivity through an interconnection between the results of the management activity, and such results are expressed by the work volume and labour input. It is also necessary to define efficiency as a qualitative-quantitative characteristic of all the phases of 
production related to the essence and contents of important economic regularities, covering the interests of all the stakeholders in business.

With regard to the growth of the issue of COVID 19 global pandemics, and the drop of production, we should proceed to reconsidering the approaches to management of industry, as well as the indicators of its functioning. To that regard, it is particularly important to implement a timely and adequate policy, to build up an efficient strategy, as well as to develop preventive response measures considering the occurring situation.

In this case, for a successful development of the enterprises of the industrial sector and for a well-developed strategy, it is necessary to become aware and assess the untypical signals revealing new challenges and opportunities (Anderson, Amode, Hartzfeld, 2010, pp. 155). The awareness of an enterprise of the need for sustainability should be fostered by an inspired leadership, by internal tensions, technological hardships or by an unexpected shock caused by the price or lack of major resources. After an enterprise analyses the main problem it can proceed to resolving it.

A proper formation of industrial enterprises can be a successful prerequisite for an economic growth and creation of innovations for the attainment of a higher economic growth, as well as the establishment of competitive advantages through implementing innovations. The success of sustainable development depends wholly on the enterprises looking for different ways of development and aiming at the achievement of improved competitiveness.

The ability of industrial enterprises to achieve competitiveness is an aggregate of incompany factors for the increase of potential and the factors established for the improvement of the effect of each separate factor (Kyurova, Dimitrova, 2013, pp. 139-140), and the development of a marketing potential is among the major system-forming components of competitive potential of enterprises along with the management, resource, innovation and financial potential. This way one can characterise the ability of a particular enterprise to keep abreast of the processes occurring on the market and to adapt its production to current and future market needs in the best way possible. This is an approach to building a better strategy of planning and a better sustainable development of industrial enterprises and to ensuring success in the development and planning of their business.

The use of inappropriate strategies by most of the industrial enterprises, on the one hand, affects their structure, their strategic goal and development programmes, their proper business planning (Pryazhnikova, 2016, p. 139). On the other hand, the use of the artificial intelligence and machines, robotics, nanotechnologies, 3D printing, genetic and biotechnology shall bring to a better and sustainable development of businesses in the industrial sector.

The process of change at which most of the enterprises experience a transition from an accelerated growth to slower-paced growth, known as industrial maturity, can be related to changes in the basic structure of industry. This growth may contribute to the concealment of some strategic mistakes, at which some of the industrial enterprises may survive or even prosper financially (Porter, 2010, pp. 283-287).

One of the main problems encountered by enterprises in the process of their functioning is their size differentiation. In the situation of an economic crisis, the successful development of businesses is of an important significance for their stability, and this refers to the state of the business entity in its sustainable development (Atanasova, Kostadinova, 2013, pp. 13-14). It is very important to realise the essence of the business enterprise as an input-output system with its ingredients, and with a subordination within it. Regarding their development, for the achievement and maintenance of their strategic vision, problem fields are established, and there are many barriers to reaching industrial growth, the main one is the predominant resourceconsuming nature of production. Resources, material ones in particular, as well as energy ones, are continuously and permanently becoming more expensive and scarcer (Iliev, 2014, pp. 5-8). 
The transition of industrial production from a resource-consuming to a resource-saving one is a very slow and often unsuccessful process.

For an industry, itself, to take a stand, it is very important to establish a competitive strategy. The determination of an industry is its choice where it is to put the line between the recognised competitors and substitute products, between the existing companies and potential participants, etc. (Porter, 2010, pp. 65-66).

The irregular and dynamic development of industry nowadays, the merger and perception of ideas of sustainable development is among the most serious prerequisites and opportunities for achieving competitive advantages. The achievement and implementation of successful strategies, policies and programmes of industrial enterprises goes through various challenges (Angelov, 2016, p. 30). The purpose of all this is to present a framework of challenges to sustainable development of the companies of industrial sector following the experience and researches of various methods of global and regional institutions and researchers.

\section{Conclusion}

In the economic situation of nowadays, the establishment and development of proper strategies and programmes for sustainable development of the enterprises of industrial sector is becoming the driving force for the improvement of business results and competitiveness of industrial enterprises. To that regard the business entrepreneurs' efforts have to be aimed at the formation of prerequisites for the successful setup, growth and development of enterprises in order to become sustainable economic entities. The achievement of such goals requires provision of and support for building and establishing an administrative and management capacity of the enterprise, development of products and services, expansion of market positions, incentives for investments, enhancement of infrastructure network, and last but not least, improvement of qualifications of manpower. 


\section{References}

Anderson, R., Amodeo, M. \& Herzfeld, J. (2010). Promyana na biznes kulturata otvatre. Sastoyanie na planetata. Izd. Knizhen tiger, Sofia, p. 153. [Промяна на бизнес културата отвътре. Състояние на планетата, Изд. Книжен тигър, София, р. 153].

Angelov, M. (2016). Challenges in integration of the concept of sustainable development at micro level. Eastern Academic Journal, 4, 30-40.

Atanasova, T., \& Kostadinova, N. (2013). Implementation of the sustainable development principles at MSE in Bulgaria. Journal of Management and sustainable development, 5, 13-14.

Executive Agency for Fostering Small and Medium Enterprises. (2013). Research of entrepreneurship and outlooks to the development of innovations in SME, /20122013/, 11-14.

Filipova, M. (2016). Strategic leadership in the trainee organization. Entrepreneurship, 4 (2), 219-228.

Iliev, Y. (2014). Industrial growth in Bulgaria - problems, prerequisites, opportunities. Ikonomiceski i Sotsialni Alternativi, (2), 5-17.

Ilieva, R. (2011). Synergy in the management of Bulgarian companies. Synergy and competitiveness of Bulgarian enterprises in a European context, 166. Retrieved from http://devorex.com/uploads/pdf/de0d2717b3dc6cca603db809b50b1d48.pdf

European Commission. (2017). Industry in Europe, facts and numbers regarding competitiveness of innovations. (B-1049 Brussels). Retrieved from http://publications.europa.eu/resource/cellar/354c1e8b-1db0-11e7-aeb301aa75ed71a1.0001.03/DOC_1

Ivanova, R. (2010). Formation of sustainable development of manufacturing companies by business analisys and internal buziness processes management. Journal of Management and Sustainable Development, 27 (3-4), 97-100.

Kindzhakova, E., \& Krachunov, H. (2015). Information base of sustainable development and environmental management systems. Sustainable development, 6 (27), 55-59.

Kirilov, St. (2018). Usavarshenstvane na ustojchivoto upravlenie na turizma. "CHVU", College of Tourism", Blagoevgrad. [Усъвършенстване на устойчивото управление на туризма. Изд. „, ЧВУ „Колеж по туризъм“, Благоевград].

Kyurova, V. (2015). Research on the impact of the innovation potential on the competitiveness of furniture enterprises. Entrepreneurship, 3 (2), 159-206.

Kyurova, V., \& Dimitrova, R. (2013). Research on the impact of the marketing potential on the competitiveness of hotel enterprises. Economics and Management, 9 (2), 22-31.

Madgerova, R. (2004). Predpriemachestvo i malak biznes v Bulgaria, IK,,Intelekt A “Blagoevgrad, Sofia. [Предприемачество и мальк бизнес в България, ИК „Интелект-А“-Благоевград, София]. 
Milcheva, D. (2012). Approaches, criteria and indicators for evaluating the efficiency of industrial production management. Journal of Management and sustainable development, 35 (4), 12-17.

Ministry of Finance. (2019). Bulgaria 2030. Analiz na sotsialno-ikonomicheskoto razvitie na stranata sled prisaedinyavaneto y kam ES. Chast 1, May 2019, Sofia. [Анализ на социално-икономическото развитие на страната след присъединяването й към EC. Чacm 1, май 2019, София]. Retrieved from https://www.minfin.bg/upload/41549/Bulgaria\%202030\%20analiz.pdf

Mishev, G. (2011). Synergy and competitiveness - quantification, Synergy and competitiveness of Bulgarian enterprises, Research project, Synergy and competitiveness of Bulgarian enterprises in a European context, p. 21. http://devorex.com/uploads/pdf/de0d2717b3dc6cca603db809b50b1d48.pdf

Nikolova, N. (2005). Methodology for strategic analysis in the development of company strategy. Journal of Management and sustainable development, 12 (1-2), 395-398.

Patarchanov, P. (2016). Situation and prospects in the development of consumer industry in Bulgaria. Annual of Sofia University "St. Kliment Ohridski", Faculty of geology and geography, 2 (109). Retrieved from

file:///C:/Users/Administrator/Downloads/13_Ann_Tom_109_geography_161175.pdf

Porter, M. (2010). Konkurentna strategia: Tehniki za analiz na industrii i konkurenti. Izd. "Klasika i stil”, Sofia. [Конкурентна стратегия: Техники за анализ на индустрии и конкуренти. Изд. “Класика и стил”, София].

Pryazhnikova, O. (2016). Budushtee trudovoy deyatelynosti: zanyatosty, navыki i karyernaya strategia v usloviyah chetvertoy prombshlennoy revolyutsii. Global challenge insight report / Ed. By K. Schwab, R. Samans; World economic forum. Geneva, 6 (159 p.). [Будущее трудовой деятельности: занятость, навыки и карьерная стратегия в условиях четвертой промышленной революции. Global challenge insight report / Ed. By K. Schwab, R. Samans; World economic forum. Geneva, 6 (159 p.)]

Schore, J. (2010). Ustoychivo rabotno vreme za vsichki. Sastoyanie na planetata. Izd. Knizhen tiger, Sofia, p. 146. [Устойчиво работно време за всички. Състояние на планетата, Изд. Книжен тигър, София].

Smallbone, D. (1995). Supporting and developing SMEs in countries in transition: a view from the west. In M. Dimitrow \& K.Todorov (Eds.) Industrial organization and entrepreneurship in transition, (pp. 3-6). Varna: Informa Intelekt.

Toncheva, T. (2013). Influence of the environment on the competitiveness of the economy, Economics and Management, 9 (4), 29-37.

Vladimirova, K. (2007). Demografsko razvitie. Strategii, politiki i programi. UI "Stopanstvo", Sofia, 182. [Демографско развитие. Стратегии, политики и програми. УИ „Стопанство“, София, 182]. 


\title{
METHODS FOR TERMINATION OF EMPLOYMENT CONTRACTS IN THE BULGARIAN PRIVATE SECTOR
}

\author{
BORYANA MILUSHEVA ${ }^{1}$ \\ СПОСОБИ ЗА ПРЕКРАТЯВАНЕ НА ТРУДОВИ ПРАВООТНОШЕНИЯ \\ В БЪЛГАРСКИЯ ЧАСТЕН СЕКТОР
}

БОРЯНА МИЛУШЕВА

\begin{abstract}
The research examines the issues related to the chosen methods for termination of employment contracts in "Perfumery Douglas Bulgaria" OOD. Based on the analysis of the normative regulation as well as the results of the conducted research, summaries, conclusions and recommendations for improvement in the company and in the Labour Code of the Republic of Bulgaria are made. Debatable questions are also raised for discussion on the basis of which a proposal is derived for a change in the National Revenue Agency (NRA) Register of Employment Contracts.
\end{abstract}

Keywords: employment contract, employer, termination, Labour Code, research, private company

JEL Codes: K31, J21, J41

\section{Въведение}

В Република България трудовите отношения между работника/служителя и работодателя, както и други отношения, непосредствено свързани с тях се уреждат от Кодекса на труда (КТ). Той е призван да закриля труда и да осигурява ефективен диалог между страните. Прекратяването на трудовия договор е част от тези взаимоотношения и е естествен техен завършек, но често в трудовата практика се появяват казуси, които показват, че е необходима оптимизация на законовите текстове в Кодекса на труда (КТ). В тази връзка следва да се посочи, че Васил Мръчков (2017), Андриана Андреева (2017), Андрей Александров (2020), Николай Стоянов (2018), Лариса Тодорова (2020), както и много други автори са осъществили множество научни изследвания, анализиращи разглежданата проблематика.

Настоящото изследване е опит за анализ върху правните възможности, относими към прекратяването на трудово правоотношение. Обект на изследването е търговско дружество с ограничена отговорност, а предметът на изследването са използваните методи за прекратяване на трудов договор. Анализират се най-честите основания за прекратяване на трудови правоотношения и ефектьт им върху страните по договора. Взима се под внимание и изплащането на обезщетения по чл. 224 (1) КТ, което е и единственото основание за обезщетение, независещо от причината за прекратяване на трудовото правоотношение и ефекта му върху човешките ресурси на компанията. Целта на разработката е чрез анализа на членовете на Кодекса на труда (КТ), засягащи

1 Student, "Faculty of Economics", South-West University "Neofit Rilski”, Blagoevgrad, Bulgaria, milusheva.boryana@gmail.com

ORCID ID https://orcid.org/0000-0003-0548-2355

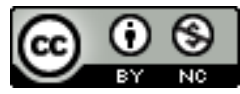

This work is licensed under a Creative Commons Attribution-NonCommercial 4.0 International License. 
прекратяването на трудов договор и чрез провеждане на пряко изследване да се направят изводи и предложения за подобрение както за анализираната фирма, така и в самия Кодекс.

\section{1. Прекратяване на трудов договор}

Трудовият договор е ключов фактор за възникването на трудовото правоотношение, чрез който се уреждат трудовите отношението между страните. С цел защита от злоупотреба страните по договора не могат да внасят в него едностранни изменения. Ако някоя от страните промени договора без съгласието на другата, то ощетената страна има правото на обезщетение и дори да прекрати договора в случаите, в които е налице незаконно изменение на клаузите или неизпълнение на поетите ангажименти по договора. Във всеки сключен договор по Кодекса на труда, задължителна част е регламентът на прекратяването му. Разбира се, този регламент се отнася за една бъдеща хипотетична ситуация, която обаче понякога има съдбовен характер за страните по договора.

Общите основания за прекратяване на трудов договор са уредени в чл. 325 (1), т.1-12 от Кодекса на труда (КТ). Така например, в т. 1 от коментираната разпоредба е регламентирано „прекратяването по взаимно съгласие“. В тази законова хипотеза една от страните по трудовия договор отправя писмено предизвестие до другата страна, която от своя страна трябва да вземе отношение по него и да уведоми първата в рамките на 7 дни от получаването му. Ако насрещната страна не стори това се приема, че тя не е сьгласна и договорьт няма как да бъде прекратен по този „елегантен начин“, защото е налице мълчаливо несъгласие на една от страните (Nachini za prekratyavane na trudov dogovor mezhdu rabotodatel i rabotnik ili sluzhitel, 2020) В тази връзка е редно да се отбележи, че връчването на заповедта, удостоверено с подписа на работника не е равнозначно на получаването на сьгласието му. Съдебната практика свидетелства за множество заповеди на това основание, които в последствие са били отменени. Примери за подобни случаи са предмет на Решение №10 от 01.02.2017 г. по гр. д. №2801/2016 г., ВКС, III г.о. и Решение №69 от 20.04.2012 г. по гр. д. №898/2011 г., ВКС, III г. о. Уволненията, отменени по съдебен ред отдавна не са рядкост. В чл. 325 (1), т. 2 е засегнат именно такъв случай, както и варианта работникът да не се върне на предишната си работа в срока, определен в чл. 345 (1), който е двуседмичен. С други думи, ако работникът не се възползва от положителния за него резултат от съдебното дело в рамките на 14 дни, работодателят прекратява трудовия договор без предизвестие.

Интерес представлява и разпоредбата на т. 6, която засяга работодателите с над 50 наети лица. Според алинеите на чл. 315 и съгласно чл. 38, ал. 1 на Закона за хората с увреждания, такива работодатели имат задължението да определят работни места, които да бъдат заети от трудоустроени кандидати. Следователно, ако се яви такъв кандидат, който има право да я заеме, а мястото не е вакантно, следва да се освободи на основание чл. 325 (1), т. 6. Въпреки че личат хуманните подбуди, които залягат в основата на споменатите членове, на практика приложението им е трудно - от една страна, защото са противоречиви, и от друга, защото засяга пряко правото на избор на работодателите.

От друга страна, ако възникне ситуация, при която работникът, поради заболяване не е в състояние да изпълнява трудовите си задължения се прилага т. 9, но само ако във фирмата няма работно място, отговарящо на намалените възможности на работника. На практика, по-логично е работодателят да оптимизира и ограничи броя на работните места, като неприсьщи на основната дейност работи се предоставят на други специализирани фирми (аутсорсинг). Други основни дейности пък се изпълняват от персонала като част от основните му задължения, което е видно от увеличения брой и 
разнообразието от изисквания при наемане на работа. В този смисъл остава усещането, че текстът е останал валиден за един безвъзвратно отминал период.

В статията е разгледан и варианта за прекратяване на трудовия договор от работника или служителя с предизвестие (чл. 326). Работникът или служителят има право да прекрати трудовия договор, като отправи писмено предизвестие до работодателя. Особеното тук е, че срокът на предизвестието не може да е по-кратък от 30 дни и по-дълъг от 3 месеца, а ако до крайната дата на трудовия договор остават помалко от 3 месеца, тогава се спазва крайната дата на договора. В ал. 3 от същия член се визират случаите, когато работникът изпълнява отчетническа дейност и предаването на материалните ценности и документация не могат да се извършат в срока от 30 дни. Тук законодателят е позволил удължаването на предаването, но за не повече от 2 месеца общо с предизвестието. Сам по себе си този срок е разумен, но практиката показва, че не се спазва. Счетоводители и отчетници са притискани да направят набързо предаването или такова изобщо не се прави, което неминуемо влече след себе си посериозни проблеми (https://www.contabil.bg/news/prekratiavane-trudov-dogovor).

В разпоредбата по чл. 327 са предвидени предимно обективни обстоятелства за прекратяване на трудовия договор от работника или служителя без предизвестие, но ще се обърне внимание на (1), т. 6, която гласи, че ако служителят „продължава“ образованието си в учебно заведение на редовно обучение или постъпва на редовна докторантура има право да прекрати трудовия си договор без предизвестие. Думата „продължава“ всъщност не се използва коректно, тъй като няма ограничение дали работникът ще започне или продължи редовното си обучение, нито дали ще смени формата си на обучение от друга към редовна. На практика, всеки човек, който запише редовна форма на обучение може да прекрати трудовия си договор на това основание.

При прекратяване на трудовия договор от работодателя с предизвестие (чл. 328) ще се обърне внимание на (2), която регламентира правото на сключилият договор за управление да подбере и назначи ръководен екип според своите изисквания. В тази алинея на него му се дава право да прекрати трудовите договори с цялото ръководство на фирмата, което може да се извърши и след започване на договора му за управление, но не по-късно от 9 месеца. Колкото и да изглежда радикална тази мярка, в условията на пазарна икономика и конкурентна среда, поемащият управлението на фирмата би трябвало да има такава възможност, за да може да изпълни поетите с договора за управление задачи (https://www.contabil.bg/news/prekratiavane-trudov-dogovor).

Работодателят има право да уволни служители, чиито дльжности не се съкращават, за да останат работници и служители с по-високи показатели и по-добра квалификация, съгласно правото на подбор по чл. 329 (1). Видно е, че не са малко водените трудови съдебни дела, когато става трудно по съдебен ред да се докаже кой служител има по-добри показатели. Нужно е да се упоменат критериите за това какво означава даден работник да „работи по-добре“- един служител може да има по-високи резултати в едно направление от задълженията си, но да бъде с по-ниски в друго. Другият вариант е законодателят да повели еднозначно, че при съкращаване на щата работодателят има право на подбор, без да има допьлнителни условности.

Законодателят е предоставил и възможност за прекратяване на трудовия договор от работодателя без предизвестие (чл. 330). Разбира се, тук най-спорният момент е (2), т. 6 по отношение на причините и процедурата за дисциплинарно уволнение. Не са малко случаите, в които със съдебно решение такава заповед е отменена и работникът е върнат на работа. От друга страна, в (2), т. 3 е дадена възможност работодателят да прекрати без предизвестие договор със свой служител, ако на същият бъде прекратено членството в съсловна организация. Това е добър пример как държавата може да предостави на 
съсловните организации контрол върху спазването на трудовата и професионална етика. (https://www.contabil.bg/news/prekratiavane-trudov-dogovor).

Някои специфични случаи са описани в членовете 333 (Закрила при уволнение), чл. 334 (Прекратяване на трудовия договор за допълнителен труд), чл. 335 (Форма и момент на прекратяване на трудовия договор). При закрилата от уволнение най-често срещани са случаите цитирани в (1), т. 2 и т. 3, при които се изисква предварително разрешение на Инспекцията по труда и на Трудово-експертната лекарска комисия.

Трудови договори за стажуване или за допълнителен труд се прекратяват с 15дневно предизвестие от работодателя или от работника. Това е облекчение и за двете страни и допринася за по-голяма гъвкавост при наемане на работници за сезонна и друга временна работа, както и за възможност младите специалисти да се включат безпроблемно в работния процес (https://www.contabil.bg/news/prekratiavane-trudovdogovor).

Един от най-интересните варианти за прекратяване на трудовия договор по инициатива на работодателя е срещу уговорено обезщетение (чл. 331). Работодателят може да предложи по своя инициатива на работника или служителя прекратяване на трудовия договор срещу обезщетение. Тук е прието правилото на мълчалив отказ или ако работника или служителя не се произнесе в 7-дневен срок се счита, че предложението не е прието. Другият момент тук е, че предложеното от работодателя обезщетение трябва да бъде не по-мальк от четирикратния размер на последното месечно брутно възнаграждение на работника. Ако последният приеме предложението, работодателят следва да изплати обезщетението в едномесечен срок от датата на прекратяване на трудовия договор, в противен случай основанието се смята за отпаднало. Използването на това основание е „чист“" начин за прекратяване на трудовите взаимоотношения, но не е много предпочитан, тъй като е и най-скъпият от финансова гледна точка. Механизмът най-често се използва, когато е невъзможно постигането на взаимно съгласие за прекратяване на трудовия договор по чл. 325 (1), т. 1 от Кодекса на труда (КТ), а не е налице и основание за едностранно прекратяване от работодателя. Така донякъде се преодоляват ограниченията, които трудовото законодателство поставя пред уволненията: не е необходимо да се посочва конкретната причина за взетото решение и няма значение дали с поведението си работникът или служителят е дал повод за вземането му.

\footnotetext{
2. Обезщетение по чл. 224 (за неползван отпуск) при прекратяване на трудово правоотношение

В Кодекса на труда (КТ) са предвидени обезщетения за напускащите служители според начина на прекратяване на трудовия договор и според това по чия инициатива се прекратява. Най-специфичното от тях е обезщетението по чл. 224 (за неползван отпуск), тъй като то се изплаща независимо от вида на основанието за прекратяване на трудовия договор. Съгласно чл. 224 (1) при прекратяване на трудовото правоотношение, работникът или служителят има право на парично обезщетение за неизползвания платен годишен отпуск пропорционално на времето, което се признава за трудов стаж. Съгласно чл. 224 (2) обезщетението за неизползван платен годишен отпуск се изчислява по реда на чл. 177 към деня на прекратяването на трудовото правоотношение, а това означава, че базата за изчисляване на обезщетението е полученото от работника или служителя среднодневно брутно трудово възнаграждение за предхождащ календарен месец, през който са отработени най-малко 10 работни дни, като няма ограничение колко назад във времето ще бъде този месец.
} 


\section{3. Прекратяване на трудови договори в „Парфюмери Дъглас България“}

ООД - изследване и резултати

Проведеният анализ се базира на концепцията за организиране на по-добра стратегия за управлението на човешките ресурси в „Парфюмери Дъглас България“ ООД - търговска верига за козметични и парфюмерийни продукти с повече от 11 години живот на пазара, с приблизителна средна стойност на числеността на персонала от 150 души. Целта на изследването е да се установи най-често използваното основание за прекратяване на трудово правоотношение и възможните мотиви за това.

Интерес представлява степента на изразеност на всяко основание за прекратяване на индивидуален трудов договор в диапазона чл. 325-335 от КТ в търговската верига, както и концентрацията на обезщетенията по чл. 224 (1) за периода 01.01.2009 г. 31.12.2019 г. За изследването са използвани данни, получени от дневника на трудовите договори и Софтуер за работна заплата и човешки ресурси Омекс ${ }^{\circledR} 2000$ на „Омегасофт“ ООД.

Основната хипотеза е, че най-използваното основание за прекратяване на трудов договор в диапазона чл. 325-335 от Кодекса на труда (КТ) е чл. 325 (1), т. 1 - по взаимно съгласие, а обезщетението по чл. 224 (1) - за неизползван редовен отпуск, като в началото на периода е най-слабо изразено, а в края на периода - най-силно.

Използвани са и работни хипотези: честотата на използването на основание чл. 325 (1), т. 1 в началото на изследвания период е най-голяма и че честотата на използването на основание чл. 326 (1) - с предизвестие от работника или служителя се увеличава с течение на времето и е най-голяма в края на изследвания период.

На фигура 1 са представени стойностите на резултатите за броя на прекратените трудови правоотношения, разделени по години и основание за прекратяване.

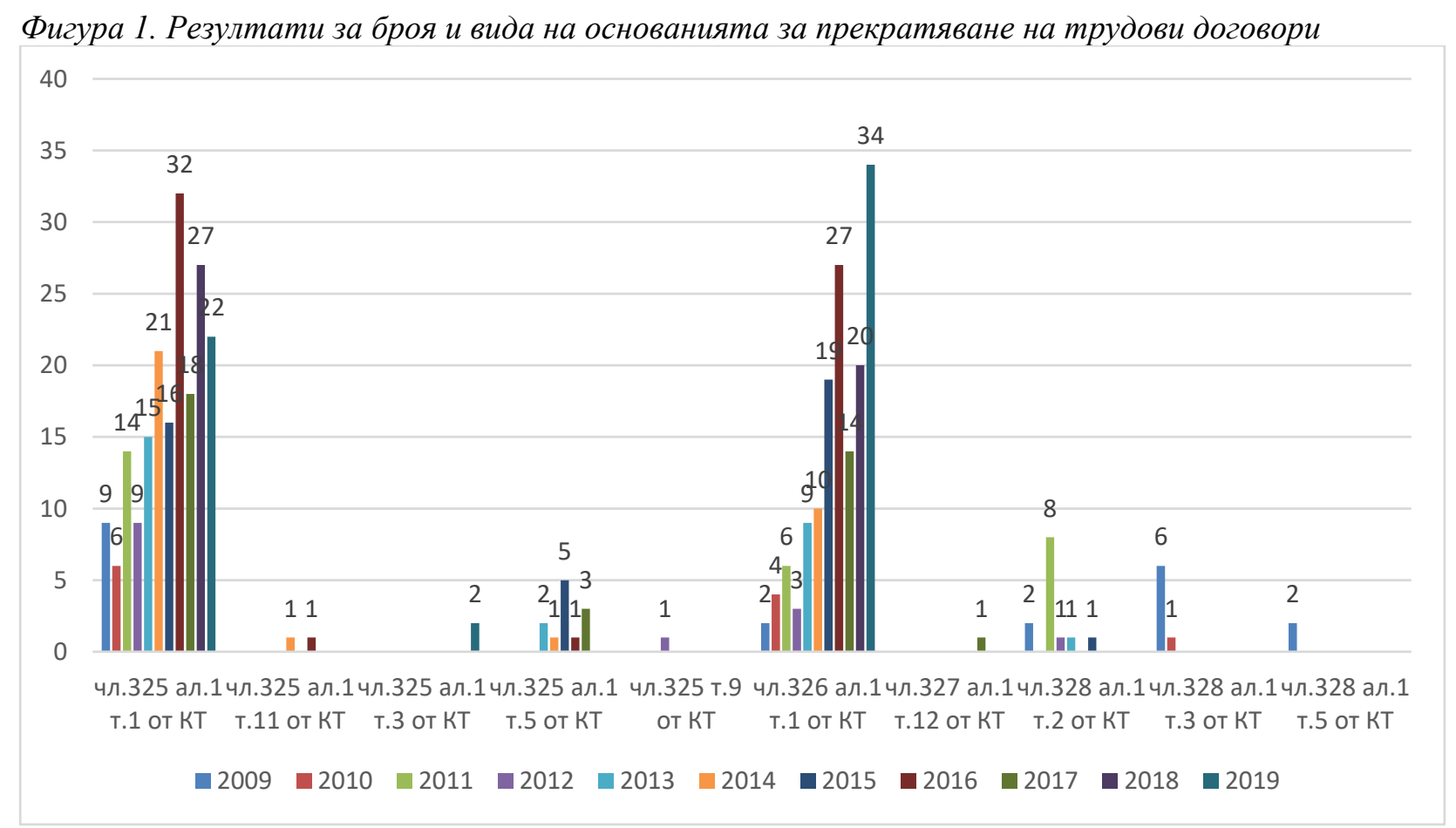

Източник: собствено проучване 
Таблица 1. Резултати от изследването за основанието и броя на прекратените договори, подредени в низходям ред

\begin{tabular}{|l|r|}
\hline \multicolumn{1}{|c|}{ Основание } & Брой \\
\hline чл.325 ал.1 т.1 от КТ & 189 \\
\hline чл.326 ал.1 т.1 от КТ & 148 \\
\hline чл.328 ал.1 т.2 от КТ & 13 \\
\hline чл.325 ал.1 т.5 от КТ & 12 \\
\hline чл.328 ал.1 т.3 от КТ & 7 \\
\hline чл.325 ал.1 т.3 от КТ & 2 \\
\hline чл.328 ал.1 т.5 & 2 \\
\hline чл.325 ал.1 т.11 от КТ & 2 \\
\hline чл.325 т.9 от КТ & 1 \\
\hline чл.327 ал.1 т.12 от КТ & 1 \\
\hline Общо & $\mathbf{3 7 7}$ \\
\hline
\end{tabular}

Източник: собствено проучване

Получените резултати сочат, че през последните единадесет години са прекратени общо 377 договора на служители на основание, попадащо в диапазона чл. 325 - 335 от Кодекса на труда (КТ). От тях най-голям брой са прекратени през 2016 г. (61 бр.), а най-мальк - през 2010 г. (едва 11 бр.). Освен това, най-голям дял от общия брой прекратени договори има основание чл. 325 (1), т. 1 от Кодекса на труда (КТ) - 189 бр., а най-мальк имат по чл. 325 (1), т. 9 и чл. 327 (1), т. 12 (само по 1 бр.). Видно е, че първата работна хипотеза по отношение на честотата на прекратени договори по взаимно съгласие в началото на периода е коректна - до края на 2014 г. изборьт на това основание е особено отличаващ се. Прави впечатление, че с течение на времето броят на прекратените договори на основание чл. 326 (1), т. 1 от Кодекса на труда (КТ) постепенно все повече се увеличава, като в края на 2019 г. вече надхвърля значително този по чл. 325 (1), т. 1 (34 бр. с предизвестие от служителя към 22 бр. по взаимно съгласие). Това означава, че втората работна хипотеза също е вярна.

Изглежда, че раздялата по взаимно съгласие традиционно е най-предпочитаният начин да се прекратят взаимоотношенията работодател - служител/работник. И все пак се наблюдава плавен преход към това служителят или работникът да подава и спазва предизвестие за напускане. Може да се каже, че това се обуславя до голяма степен от факта, че в последните години като цяло в страната се установява т. нар. „текучество“. То се приема като знак за некоректност и нестабилност на дадена организация, а вече се е превърнало в повсеместно явление.

Таблица 2. Резултати за броя на обезщетенията на основание чл. 224 (1) при прекратяване на трудови договори, в дни

\begin{tabular}{|l|r|}
\hline \multicolumn{1}{|c|}{ Година } & Обезщетения по чл. 224 (1), дни \\
\hline 2009 & 91 \\
\hline 2010 & 24 \\
\hline 2011 & 50 \\
\hline 2012 & 20 \\
\hline 2013 & 32 \\
\hline 2014 & 51 \\
\hline 2015 & 68 \\
\hline 2016 & 238 \\
\hline 2017 & 153 \\
\hline 2018 & 220 \\
\hline 2019 & 200 \\
\hline Общо & $\mathbf{1 1 4 7}$ \\
\hline
\end{tabular}

Източник: собствено проучване 
Що се отнася до обезщетението за неползван редовен годишен отпуск, безспорно то е най-често срещаното от видовете обезщетения. Таблично са представени стойностите на резултатите за броя на дните, за които е изплатено обезщетение по чл. 224 (1) при прекратяване на трудови правоотношения, разделени по години (Таблица 2). Получените резултати се дължат на факта, че обезщетение на основание чл. 224 (1) се полага независимо от основанието за прекратяване на договора. Изненадващото е, че имайки предвид, че в края на 2019 г. предприемачите в Р. България оценяват като найголяма пречка за развитието на бизнеса липсата на кадри, според изследването това не е годината с изплатени най-много обезщетения за неползван отпуск. С други думи, компанията е успяла да осигури на служителите си възможност да почиват, въпреки недостига на човешки капитал като цяло.

Така основната хипотеза се доказа само частично, защото най-голям брой дни, за които е изплатено обезщетение за неползван годишен отпуск е бил през 2016 г. за 238 дни, следван от 2018 г. за 220 дни. Действително, в последните три години от разглеждания период са изплатени най-много дни, но 2019 г. се нарежда на трето място с обезщетения за общо 200 дни.

При анализа на получените резултати, с цел създаване на добра основа за подобряване на цялостната политика по отношение на човешките ресурси в компанията, възниква въпросът как стои разглежданият проблем на национално ниво. Установи се, че при интерес за проследяване на тази тенденция за страната няма официален източник, от който да се вземат официални достоверни данни, което води до създаване на неефективни стратегии за управление на човешкия ресурс от работодателите.

Връщайки се на въпроса за достоверен и своевременен източник на информация, за използвано основание за прекратяване на трудов договор, е редно да се отбележи, че липсата му е резонна, тъй като към момента този тип информация не е част от данните, които се съдържат в уведомлението по чл. 62. от Кодекса на труда (Фигура 2).

Фигура 2. Образеи на уведомление по чл. 62, ал.5 от Кодекса на труда (КT)

УВЕДОМ Л Н ИЕ

по чл. 62, ал. 5 от Кодекса на труда

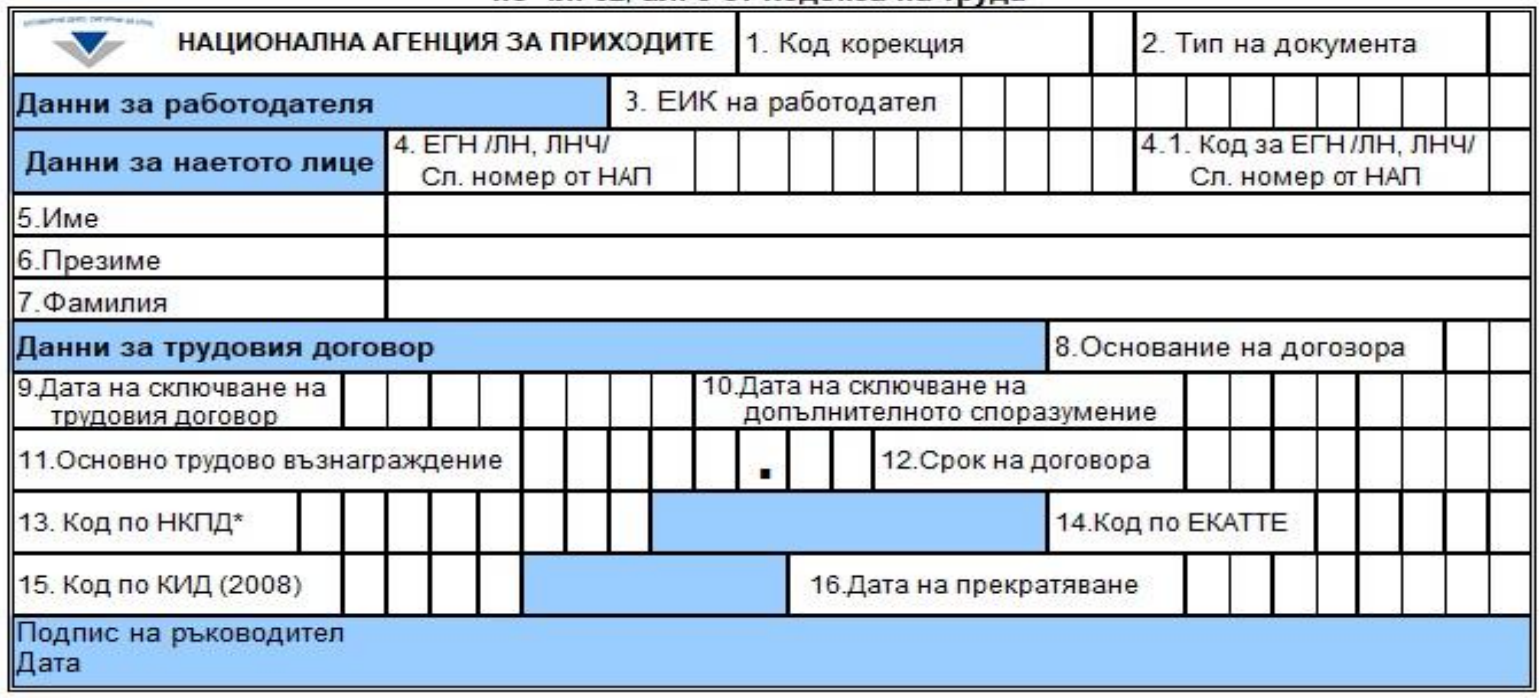

Източник: Наредба за изменение и допълнение на Наредба № 5 от 2002 г. за съдържанието и реда за изпращзане на уведомлението по чл. 62, ал. 5 от Кодекса на труда

Ако това се промени, регистърьт на трудовите договори на Националната агенция за приходите (НАП) ще се обогати значително, като ще стане възможно извеждането на бърза справка в реално време. 


\section{Заключение}

Членството на Р. България в Европейския съюз и резултатът от свободното движение на хора, стоки и капитал създават съвременните предизвикателства за пазара на труда. В страната се наблюдава тенденция за честата смяна на работодатели от работници/служители с или без сериозно основание, което създава значителен дискомфорт за работодателите и в частност на разглежданата фирма. За предлагащите работа, предвид настоящата действителност, е трудно да заменят даден работник с нов за кратък период от време и често се разчитат на предизвестието. Според разгледаните данни през последните години може да се наблюдава релация между нарастването в броя на прекратяване на трудови правоотношения по чл. 326 (1) и броя на изплатените обезщетения по чл. 224 (1) в права пропорционалност: работодателят предпочита да плати неползван отпуск, вместо да го предостави за ползване при входиране на предизвестието за напускане. От тук си проличава и сложната ситуация с кадри, в която се намират работодателите.

Редно е да се обръща задълбочено внимание на индивидуалните характеристики на всеки отделен случай, а не да се прибягва до стандартните основания. Работодателите само биха спечелили, ако въведат „изходяща анкета“, в която освобождаваните служители да вписват тяхната гледна точка на причината за напускането си. Това ще даде възможност на ръководството да анализира по-добре ситуацията с човешкия ресурс на компанията, както и да изгради по-добра стратегия за в бъдеще.

От друга страна, полезно би било подобряването на някои специфични текстове в Кодекса на труда (КТ), като случая с чл. 327 (1), т. 6, разгледан по-горе. Това би внесло повече яснота във взаимоотношенията между работодател и служител и би намалило предпоставките за възникване на напрежение между страните.

Не на последно място, в условията на пряка конкуренция между работодателите за компетентен и квалифициран персонал е жизнено важно да се разполага с достоверни данни за предишния опит на кандидатстващия за обявеното място, както и достоверна информация за основанията за прекратяване на трудовите му правоотношения. Липсата на тази основна достоверна информация води до изкривявяане на реалната оценка на кандидата и съответно може да нанесе сериозни щети върху съответния работодател. В тази връзка, допълването на регистьра на трудовите договори на Националната агенция по приходите (НАП) с основание за прекратяване може да окаже положителен ефект както за законодателя при цялостното разглеждане на следващи промени в Кодекса на труда (КТ), така и за бъдещи изследвания. Нещо повече, възможно е допълненият регистьр да прерасне в електронно трудово досие. 


\section{Библиография}

Aleksandrov, A. (2020). Prakticheski problem na trudovoto parvo, svarzani s prekratyavaneto na trudovoto pravootnoshenie. [Александров, А. (2020). Практически проблеми на трудовото право, свързани с прекратяването на трудовото правоотночение]. Retrieved from:

http://trudipravo.bg/component/content/article?id=2752:prakticheski-problemi-na-trudovoto-pravosvarzani-s-prekratyavaneto-na-trudovoto-pravootnoshenie.

Andreeva, A., Danev, V. (2017). Prekratyavane na bezsrochen trudov dogovorproblematika, perspektivi i tendentsii v usloviyata na savremenna pazarna ikonomika. [Андреева, А., Данев, В. (2017). Прекратяване на безсрочен трудов договор проблематика, перспективи и тенденции в условията на съвременна пазарна икономика]. Retrieved from: https://papers.ssrn.com/sol3/papers.cfm?abstract_id=3305010.

Kodeks na truda. (2020). Кодекс на труда. (2020). Retrieved from: https://www.mlsp.government.bg/index.php?section=CONTENT\&I=226\&lang=.

Mrachkov, V. (2017). Subektivno parvo i subektivni trudovi prava, izd. "Sibi“. [Мръчков, В. (2017). Субективно право и субективни трудови права, изд. „Сиби“].

Nachini za prekratyavane na trudov dogovor mezhdu rabotodatel i rabotnik ili sluzhitel. (2020). Начини за прекратяване на трудов договор между работодател и работник или служител. (2020). Retrieved from: https://www.contabil.bg/news/prekratiavane-trudov-dogovor.

Naredba za izmenenie i dopalnenie na Naredba № 5 ot 2002 g. za sadarzhanieto i reda za izprashtane na uvedomlenieto po chl. 62, al. 5 ot Kodeksa na truda. [Наредба за изменение и допьлнение на Наредба № 5 от 2002 г. за съдържанието и реда за изпращане на уведомлението по чл. 62, ал. 5 от Кодекса на труда]. Retrieved from: https://dv.parliament.bg/DVWeb/showMaterialDV.jsp?idMat=134512

Softuer za rabotna zaplata i choveshki resursi Omeks ${ }^{\circledR} 2000$. (2020). Софтуер за работна заплата и човешки ресурси Омекс® 2000. (2020). Retrieved from: https://www.omegasoft.bg/omeks2000/products\#horizontalTab2.

Stoyanov, N. (2018). Prekratyavane na trudoviya dogovor bez predizvestie. Vtoro dopalneno izdanie, izd. "Ciela". [Стоянов, Н. (2018). Прекратяване на трудовия договор без предизвестие. Второ допълнено издание, изд. Сиела].

Supreme Court of Cassation, Decision №10 of 01.02.2017 in a civil case №2801/2016. [Върховен касационен съд, Решение №10/01.02.2017 2. по гражданско дело №2801/2016]. Retrieved from: http://www.vks.bg/pregledakt?type=otdelo\&id=7DD46E0145AECCBCC22580BA0047A022.

Supreme Court of Cassation, Decision №69 of 20.04.2012 in a civil case №898/2011.

[Върховен касационен съд, Решение №69/20.04.2012 г. по гражданско дело №898/2011]. Retrieved from: http://www.vks.bg/pregled-akt?type=otdelo\&id=1BEEB174124D4FE6C22579E3004AB94C.

Todorova, L. (2020). Vidove obezshteteniya pri prekratyavanena trudovoto pravootnoshenie. [Тодорова, Л. (2020). Видове обезщетения при прекратяване на трудовото правоотношение]. Retrieved from: http://trudipravo.bg/component/content/article?id=299: mat25. 


\title{
JAPAN'S POLICY AGAINST THE CRIME OF STALKING
}

\section{NIKOL NIKOLOVA ${ }^{1}$}

\begin{abstract}
Stalking is a relatively newly criminalized type of behavior that should be brought to public attention and awareness. Through a review of statistical data, the relevant anti-stalking act, media portrayal and social impact, the article aims to provide an overview of Japan's response to stalking acts. In Japan, stalking is listed as a criminal offence punishable by imprisonment with work and fines. It can be concluded that almost all victims receive additional guidance, however, this has been criticized as insufficient. Statistical studies with a wider scope should be introduced, while the law should be revised regularly and expanded to include clinical therapy for perpetrators.
\end{abstract}

Keywords: stalking, Japan, legislation

JEL Codes: $K 14$

\section{Introduction}

Stalking generally means following an individual around. Similarly, the term stalker refers to a person who is extraordinarily interested in another individual.

Originally, the verb "stalk" comes from the English language and between the 16th and 20th century it was used to refer to the act of creeping up to catch or harm a person or animal.

In recent decades, however, the meaning of this word has changed. In latter part of the twentieth century, the media began to refer to the act of a person persistently pursuing others and annoying or frightening them as "stalking". It was mainly cases of celebrities falling victim to their alleged fans that gained media attention. In other words, at first stalking was regarded as a new form of an obsessive fan pursuit (Pathé, Mullen, Purcell, 2000). Occasionally, these acts would surpass simple pursuit and perpetrators would also resort to violence, sometimes with a fatal end for the victim - for example, the murder case of John Lennon.

As society has become more and more aware of instances of people persistently pursuing and thereby bothering, scaring or harming others, and as it has become clear that these acts are criminal and illegal, the terms "stalking" and "stalker" have also come to be used to refer to such criminal acts and criminals (Pathé, Mullen, Purcell, 2000).

Having said that stalking became an important issue in the 20th century, it should be noted that it mostly came to light in the eighties and nineties. The first anti-stalking law was enacted in 1990 by the US (California Penal Code Section 646.9). Today, all 50 States of America have special criminal anti-stalking laws in place. Japan, Canada, Australia, India and most of the EU member states have since followed suit and introduced stalking as a specific offence.

This article will focus on the set of circumstances surrounding the stalking phenomenon in Japan. The reason for choosing this country is the author's personal experience while residing there. Through a review of statistical data, the relevant anti-stalking act, media

\footnotetext{
${ }^{1}$ Student, "Faculty of Economics", South-West University "Neofit Rilski”, Blagoevgrad, Bulgaria, tenbun@abv.bg ORCID iD https://orcid.org/0000-0001-7574-7449
}

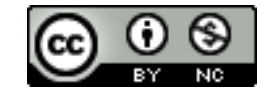

This work is licensed under a Creative Commons Attribution-NonCommercial 4.0 International License. 
portrayal and social impact, the article aims to provide an overview of Japan's response to stalking acts.

\section{Definition and statistics}

Japan has borrowed the terms "stalking" and "stalker" from English; however, "stalking" is sometimes referred to as "tsukimatoi" in Japanese, which can be translated as "to follow someone around". It has been pointed out that pursuing someone by following them around is the most basic form of stalking. The Merriam Webster Dictionary gives the following legal definition of stalking:

$\checkmark$ the act or crime of willfully and repeatedly following or harassing another person in circumstances that would cause a reasonable person to fear injury or death especially because of express or implied threats;

$\checkmark$ broadly: a crime of engaging in a course of conduct directed at a person that serves no legitimate purpose and seriously alarms, annoys, or intimidates that person.

NOTE: Stalking is often considered to be aggravated when the conduct involved also violates a restraining order protecting the victim.

With advances in technology, stalking cases have only escalated in recent years, with the exact numbers being hard to define in light, for example, of cyber stalking, and victims' reluctance to report (Yoshimatsu, 2015; Al Jazeera, 2014). In the US, millions of people are victims of stalking every year, with one source citing the number between 6.5 and 8.8 million (Smith at all, 2018).

Statistical data on stalking in Japan, provided by the country's National Police Agency is available starting the end of November 2000, when the Anti-Stalking Act (Act on Regulation of Stalking and Similar Acts, 2000) was first enacted. The National Police Agency publishes yearly data regarding the response to stalker and domestic violence cases, with the latest figures published in the beginning of March 2020.

What is immediately noticeable and hardly surprising is the gender ratio. Roughly $84 \%$ of victims are female, while over $80 \%$ of perpetrators are male. Most of the victims are in their twenties, while most of the stalkers are in their twenties or thirties. In around $75 \%$ of the cases, the victim and the stalker know each other (friends, colleagues, (formerly) in a romantic relationship, (formerly married), (National Police Agency of Japan, 2020).

The number of consultations, i.e. reported cases, (Figure 1) has been at a high level since 2012, but started to decrease in 2018, coming down to 20912 in 2019 (down 644 cases, or $3 \%$, compared to the previous year). Overall, however, consultations regarding stalking cases have doubled over the past decade.

Figure 1. Changes in the number of consultations regarding stalker cases

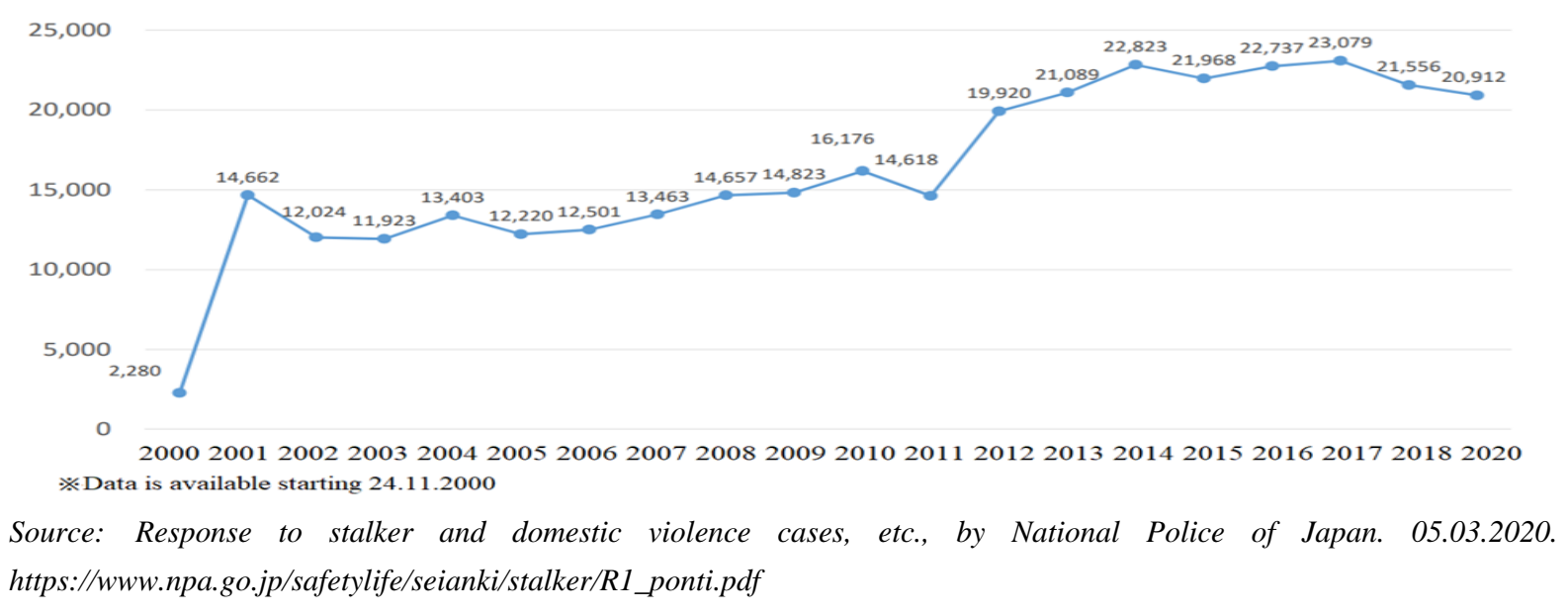


The number of issued warnings based on the Anti-Stalking Act (Figure 2) have increased since 2012, but then decreased from 2017, down to 2052 cases (399 cases, or $16.3 \%$ less compared to the previous year) in 2019. The number of prohibition and similar orders was on a slowly increasing trend, but it spiked sharply from 2017, increasing to 1375 cases $(+218$ cases, $+18.8 \%$ compared to the previous year) in 2019 , the highest number since the enforcement of the law.

Figure 2. Issued warnings and prohibition orders based on the Act on Regulation of Stalking and Similar Acts, after revision

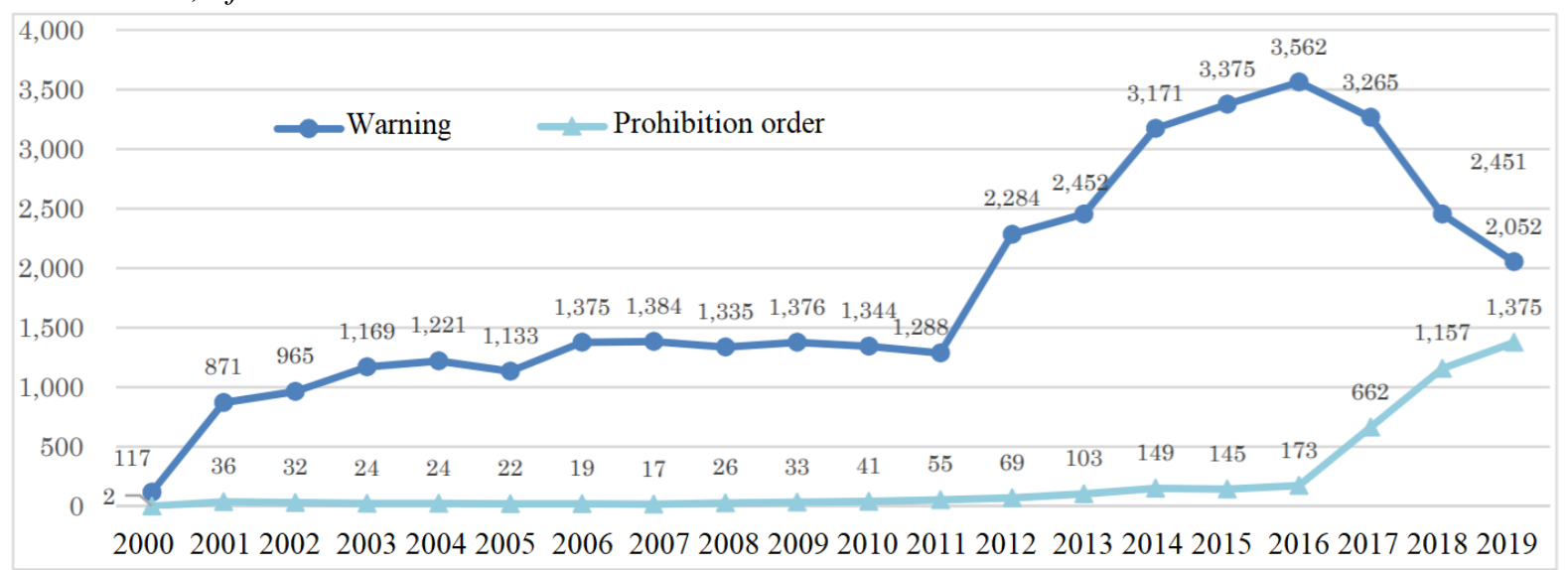

Source: Response to stalker and domestic violence cases, etc., by National Police of Japan. 05.03.2020. https://www.npa.go.jp/safetylife/seianki/stalker/R1_ponti.pdf

2012 also marked the increase of the number of arrests for violations of the AntiStalking Act. In previous years, the number had ranged between 150 and 250, whereas in 2012 it surpassed 350, and continued to grow steadily, peaking at 926 arrests in 2017, but then decreased slightly from 2018 and was down to 864 in 2019 (-0.7\% compared to the previous year).

On the other hand, the number of arrests for criminal offenses and other special law offenses related to stalker cases remained at a high level since 2012 (reaching close to or over 1900 cases in 2014, 2015 and 2016), but it decreased from 2017, and there were 1,491 such cases in 2019 (-103 cases compared to the previous year, or $-6.5 \%$ ).

The police itself offers assistance to both victims and stalkers. Figure 3 displays the instances in the last five years (2015-2019) where victims and stalkers have received aid. If we compare the reported cases in Figure 1, it can be concluded that almost all victims receive additional guidance. Assistance offered or mediated by the authorities also includes teaching damage prevention measures and negotiation tactics, introduction to private organizations that carry out damage prevention activities, use of police facilities as a place to discuss damage prevention, teaching or lending items that contribute to damage prevention, delivery of documents to the effect that warnings have been implemented, etc. 
Figure 3. Trends in crime prevention guidance for stalker victims and guidance warnings for perpetrators

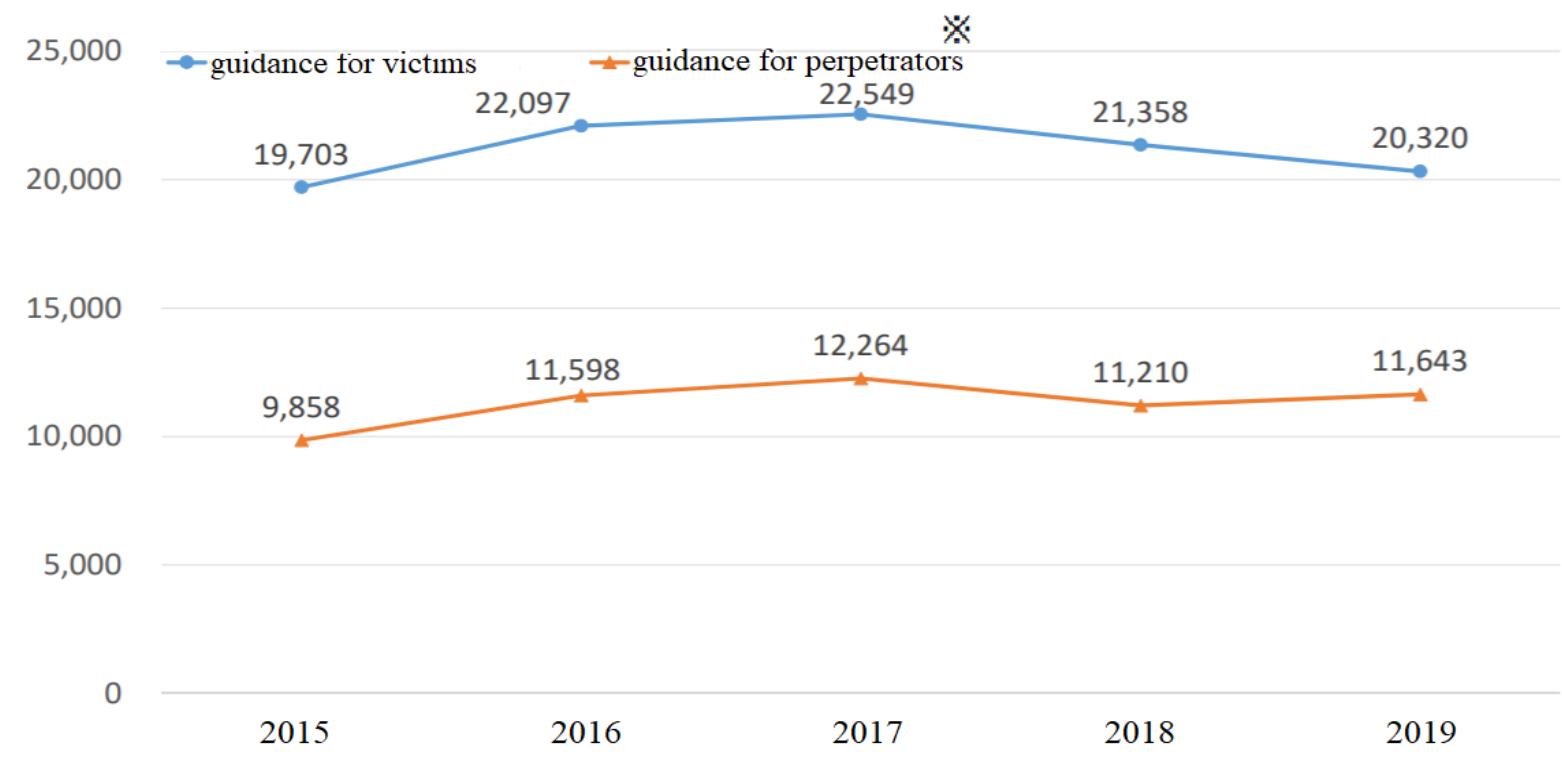

Source: Response to stalker and domestic violence cases, etc., by National Police of Japan. 05.03.2020.

https://www.npa.go.jp/safetylife/seianki/stalker/RI_ponti.pdf

Table 1 shows the number of issued restraining orders based on the Anti-Stalking Act in 2019. The 1375 orders comprise around 6,6\% of all stalker cases reported during the same year. Additional data suggests that 153 of the restraining orders relate to an extended penalty from previous years.

Table 1. Application of restraining orders, etc. based on the Act on Regulation of Stalking and Similar Acts, after revision

O Implementation of restraining orders

\begin{tabular}{|c|c|c|c|c|}
\hline \multirow{2}{*}{ No. of cases } & \multicolumn{2}{|c|}{ Without warning } & \multicolumn{2}{c|}{ With warning } \\
\hline \multirow{3}{*}{1,375} & \multicolumn{2}{|c|}{1,242} & \multicolumn{2}{c|}{133} \\
\cline { 2 - 5 } & Ordinary & Emergency & Ordinary & Emergency \\
\cline { 2 - 5 } & 684 & 558 & 90 & 43 \\
\hline
\end{tabular}

Source: Response to stalker and domestic violence cases, etc., by National Police of Japan. 05.03.2020.

https://www.npa.go.jp/safetylife/seianki/stalker/R1_ponti.pdf

\section{Legal frame}

Act No. 81 of the year 2000, also known as Anti-Stalking Act and Law on Regulation of Stalking and Similar Acts, states the following as its purpose:

Article 1 This law aims to provide for the necessary regulation of stalking, such as sanctioning stalking acts, and establishes measures for assistance to the aggrieved party, thereby preventing harm to the body, freedom and dignity of the individual. In addition, it aims to contribute to the safety and peace of the nation's lives.

\subsection{Legal definitions}

The Law defines the following acts as "stalking": 
Article 2. In this Act, the term "following, etc." (NB: tsukimatoi, the Japanese word for stalking and similar behavior) refers to acts performed with the purpose of satisfying romantic feelings or other favorable feelings for a specific person or feelings of resentment towards a specific person or his/her spouse, a direct relative or co-resident, or any other person who has a close relationship with the specific person in social life.

Further, according to the same article, such acts include, but are not limited to: following, stalking, ambushing a person, monitoring their actions or barging in on them without authorization at their home, school, workplace or other whereabouts; attempting contact despite rejection (via phone, fax, email, etc.); demanding meetings, a relationship or any other nonobligatory activities; sending objects that cause fear and disgust (animal corpses, garbage, etc.); extremely vulgar or violent speech or actions; defamation; spreading files that cause sexual shame.

\subsection{Warnings}

Further, Article 3 of the law clearly prohibits anyone from threatening another party's safety, residence, etc., dignity or their freedom of action by stalking them, while Article 4 lists the warnings that authorities must issue when violations of the law have been confirmed.

Article 4. Paragraph (1) The superintendent or head of police station, upon receiving a request from a victim, and if a violation is confirmed and it is recognized that there is a risk of the stalking act being performed repeatedly, can issue a warning to the person who performed the act that it should not be repeated, as stipulated by the rules of the National Public Safety Commission.

Paragraph (3) When issuing a warning, the superintendent or head of police station shall promptly notify the person who has made the request under article 4, Paragraph 1 of the content and date and time of the warning.

\subsection{Restraining orders}

Restraining orders, or prohibition orders, as the Japanese Law calls them specifically, can be issued in the following circumstances described in Article 5:

Paragraph (1) In the case of an act that violates the provisions of Article 3, when it is assesed that there is a risk that the person who has performed the act may repeat it more than once, the Public Safety Commission may, at the request of the aggrieved party, or by authority, order the following matters, as provided for in the National Public Safety Commission rules:

1. Not to repeat the act further.

2. Items necessary to prevent the act from being repeated further.

Paragraph (2) When the Public Safety Commission intends to issue an order pursuant to the provisions of the preceding paragraph (hereinafter referred to as "prohibition order, etc."), a hearing shall be conducted regardless of the classification of procedures for making an opinion statement pursuant to the provision of Article 13, paragraph 1 of the Administrative Procedure Act (Act No. 88 of 1993).

Paragraph (3) Regardless of the provisions of the preceding paragraph and Article 13 (1) of the Administrative Procedures Act, the Public Safety Commission, in the case described in paragraph (1) for acts that violate the provisions of Article 3, in order to prevent the impairment of the physical safety, honor or peace of residence, etc., or the freedom of movement of the aggrieved party, when it is deemed that there is an urgent need to prevent such a situation, may issue a prohibition order by request or by ex officio without giving an opportunity for hearing or justification. In this case, the Public Safety Commission that has issued the prohibition order, etc. shall conduct a hearing within 15 days from the date of the prohibition order. 
Paragraph (5) If one Public Safety Commission has issued a prohibition order, other Public Safety Commissions may not give a prohibition order, etc. to the same person for acts that violate the provisions of Article 3 pertaining to the prohibition order, etc.

Paragraph (8) The effect of the prohibition order, etc. shall be one year from the date it was issued.

Paragraph (9) If the Public Safety Commission, in the case of issuing a prohibition order, etc., finds that it is necessary to continue the prohibition order, etc. after the lapse of the period set forth in the preceding paragraph, the period of validity of the prohibition order, etc. may be extended for one year at the request of the aggrieved party or ex officio. The same shall apply when further extension is made after the lapse of the extension period.

\subsection{Penalties}

Article 18. Anyone who has committed stalking is to be punished by imprisonment with work for not more than one year or a fine not exceeding one million yen.

Article 19. Paragraph (1) A person who acts as a stalker in violation of a prohibition (restraining) order, etc. (limited to those pertaining to Article 5, paragraph 1, item 1; the same shall apply hereinafter) shall be punished by imprisonment with work for not more than two years or a fine of not more than two million yen.

Article 20. In addition to what is provided for in the preceding article, a person who violates a prohibition order, etc. shall be punished by imprisonment with work for not more than six months or a fine of not more than 500,000 yen.

\subsection{Police and other assistance}

Article 7 states the police's obligations to assist in stalking cases.

Article 7. Paragraph (1) The police, after receiving a request from the victim of a stalking act, etc. that he/she wants to receive assistance in order to prevent damages related to the stalker act, has to provide instructions for measures to prevent damages related to stalking, etc. and other necessary assistance provided by the rules of the National Public Safety Commission.

Paragraph (2) In providing the assistance set forth in the preceding paragraph, the police chief, etc., shall endeavor to work closely with the relevant administrative organs or related public and private organizations.

Further to this, articles $6,8,9,10,11$ consider other essential aspects:

$\sqrt{ }$ Prohibition of information provision related to stalking, etc.

$\sqrt{ }$ Required confidentiality from law enforcement officials and other persons involved.

$\sqrt{ }$ Relevant personnel training on the characteristics of stalking, as well as awareness promotion necessary to deepen the understanding of the human rights of the aggrieved party.

$\sqrt{ }$ Support for stalking and other counterparties at women's bureaus and other appropriate facilities, support for staying in private facilities, and accommodation in public rental housing.

$\sqrt{ }$ Assistance from residents in the area where the stalking act, etc. was performed.

$\sqrt{ }$ Promotion of research on methods for rehabilitating persons who have stalked, etc., and methods for restoring the mental and physical health of victims.

$\checkmark$ Spreading knowledge through educational activities, publicity activities, etc.

$\sqrt{ }$ Cooperation and support with voluntary organizational activities of the private sector.

\section{Discussion}

While the listed aspects appear to be adequate and inclusive, it should be noted that some of them have been added post-factum, as the Anti-Stalking Act has been found severely 
lacking in recent years, leading to two revisions in order to close legal loopholes and increase enforcement (Itakura, 17.10.2019). Both revisions took place in response to murder cases of stalker victims - in 2013 the Act was expanded to include email harassment after the Zushi case (2012), and in 2017 to cover social media after the Koganei case (2016). The changes brought a significant surge in reported cases (as evident by the data in Figure 1). Until then, these forms of communication had not been explicitly covered in the law. The Act itself was only introduced after the murder of a 21-year-old student back in 1999 (Okegawa case, 1999) - a case which led to great public outrage, because the victim had sought help from the police numerous times without them taking action (Beyer, 2018; Itakura, 17.10.2019).

The police have been criticized on more than once occasion for not taking necessary precautions, either downplaying the severity of the situation or not taking emergency measures, such as the so-called "provisional order" which allows police to warn a stalker once and arrest him immediately upon further violations (this measure had not been used even once between 2000 and 2014).

It has also been pointed out that the law itself, even with its recent amendments, does not allow for immediate action in terms of confining perpetrators to ensure victims' safety. Instead, one must go through the often-tedious process of submitting an official request for a warning and rely on assistance with questionable effects, considering stalkers' potentially escalating dangerous behavior (Yoshimatsu, 2015). Fines and restrictions for stalkers have also been found lacking or too weak, as stalkers are generally aware of them and find ways to go around them - for example, police have reported that in some cases it has been hard to get ahold of stalkers in order to present them with their first warning, because perpetrators have "made themselves scarce", thereby prolonging or avoiding prosecutions.

While under the new law, police can issue restraining orders without prior warning in emergency cases (the decline in warnings and rise in restraining orders since 2017 reflects this change well, see Figure 2), it can hardly be argued that measures against stalkers often come too late, as they are usually arrested, fined and confined only after they have violated a restraining order. For example, it can be more beneficial for the victim if the stalker is charged on grounds of intimidation and defamation instead (Itakura, 05.09.2019). The number of warnings and restraining orders against stalkers is also considerably small compared to the total number of reported cases (Figure 1) and no report exists to explain how the rest of these cases have played out.

What should be considered in the future is the victim's and stalker's psyche. Japan is a rather close-minded society when it comes to revealing personal matters, and even today this is generally frowned upon. This is considered one of the reasons why not all cases of stalking or domestic violence are reported - there exists this stigma of "causing others trouble" and "shame", which may seem peculiar and illogical to most Westerners nowadays, but is considered the norm in Japan. Especially if the aggressor is one's (former) spouse or romantic partner, or one's superior at work, victims may be discouraged to seek help, while police, on the other hand, have been reported to downplay the situation and prefer not to interfere, for example, in "marital matters" (response to domestic violence may be even worse than to stalking, as domestic affairs are generally presumed off-limits).

A stalker's psyche, on the other hand, is a lot more complex, and there have been many publications by scientists and stalker victims alike concerning stalkers' mentality, behavior and motives. One thing that the law should account for is precisely stalkers' unpredictability. On the stalker's side, there is almost always some kind of mental issue at play, and while official warnings, fines and imprisonment are logical from a legal point of view, the assistance of medical professionals should be sought early on so as to determine the perpetrator's state of mind and thereby the likelihood for further, more dangerous actions. To rely simply on official 
warnings, for example, and a stalker's good will to follow through and accept them, would be to put the victim's life at risk. A maximum imprisonment of two years and fine of two million yen (currently approximately 17300 EUR or 33900 BGN) may discourage some, but not all with a feeble state of mind. In fact, this may have the opposite effect.

Currently there is one major NPO specializing in counseling not only for harassment victims, but also perpetrators - NPO Humanity. As its creator and director is also a victim of stalking, the company takes interest in stalker cases and aids both sides of the "argument". The company has reportedly dealt with more than 500 stalkers and employs the help of certified psychiatrists and innovative therapies. It stands firm on the belief that stalkers should be offered professional help and that the Anti-Stalking Act should be expanded (Itakura, 17.10.2019).

\section{Conclusion}

Japan is certainly one of the world's pioneers regarding anti-stalking measures. Compared to other countries, where the issue has not yet been recognized, much less included in the penal code, Japan is several steps ahead. However, there is still much room for improvement.

Assistance and counseling, both for victim and aggressor, should be the norm. Stalking should be viewed as not only a crime that requires punishment, but also as a condition that requires treatment. Additionally, social campaigns raising awareness and encouraging victims to confide should be promoted extensively. In a conservative and rather closed-off society like Japan, with an otherwise low criminal rate, victims may find it hard to recognize dangerous behavior, or to act sensibly in cases where their safety is endangered. While media exposure of similar cases the \#MeToo Movement (2019), for example has encouraged victims to step forward, many hurdles still exist.

Available statistics from the National Police Agency of Japan offer insight which - at this point in time - Bulgaria, the author's homeland, is not researching or reflecting on (for example, the only available statistics on domestic violence in Bulgaria are based on a counseling company's logs). Statistical research in Japan should be broadened to include other aspects, like outcome of stalker cases, stalkers' previous criminal record (ex. whether this is their first time as a stalker), psychological profile or results of psychological inspection, respectively, to name but a few. The Anti-Stalking Act should be continuously developed to incorporate different potential scenarios.

In comparison to Japan, stalking has been sanctioned in Bulgaria since 2004 under Article 5 of the Law on protection against discrimination. According to this law, only coercive administrative measures, and administrative penalties in the form of fines may be imposed. As of 2019, however, stalking has been added to the Penal code and is punishable by imprisonment of up to one year or probation. 


\section{References}

Act on Regulation of Stalking and Similar Acts. (2000). Retrieved from https://elaws.egov.go.jp/search/elawsSearch/elaws_search/lsg0500/detail?lawId=412AC1000000081

Aljazeera. (2014). Japan's stalking crisis. [Video file] Retrieved from: https://www.aljazeera.com/programmes/101east/2014/12/japan-stalking-crisis2014128103943425348.html.

Beyer, Vicky L. Ladies \& The Law: The Murder That Resulted in Japan's Anti-Stalking Act. 20.12.2018. Savvy Tokyo. Retrieved from https://savvytokyo.com/ladies-the-law-themurder-that-resulted-in-japans-anti-stalking-act/.

California Penal Code. Retrieved from: https://leginfo.legislature.ca.gov/faces/codes_displayText.xhtml?lawCode=PEN\&divi $\underline{\text { sion }=\& \text { title }=15 . \& \text { part }=1 . \& \text { chapter }=2 . \& \text { article. }}$.

Deutsche Welle. (2019). Japan: Journalist wins high-profile \#MeToo case. Retrieved from https://www.dw.com/en/japan-journalist-wins-high-profile-metoo-case/a-51715924

Itakura, K. (2019). Setting Stalkers on the Road to Rehabilitation. The Nippon Communications Foundation. Retrieved from https://www.nippon.com/en/indepth/d00504/setting-stalkers-on-the-road-to-rehabilitation.html.

Itakura, K. (2019). Uchizawa Junko: Confessions of a Japanese Stalking Victim. The Nippon Communications Foundation. Retrieved from https://www.nippon.com/en/people/bg900061/uchizawa-junko-confessions-of-ajapanese-stalking-victim.html?cx_recs_click=true.

Merriam-Webster.com Legal Dictionary, Merriam-Webster. Retrieved from https://www.merriam-webster.com/legal/stalking. Accessed 27 May. 2020.

Mullen, P. E., Pathé, M., \& Purcell, R. (2000). Stalkers and their victims. Cambridge University Press. Retrieved from http://catdir.loc.gov/catdir/samples/cam032/99044607.pdf.

National Police Agency of Japan. (2020). Response to stalker and domestic violence cases. Retrieved from https://www.npa.go.jp/safetylife/seianki/stalker/R1_ponti.pdf.

NPO Humanity. Retrieved from https://www.npo-humanity.org/en/.

Smith, S. G., Zhang, X., Basile, K. C., Merrick, M. T., Wang, J., Kresnow, M., \& Chen, J. (2018). The National Intimate Partner and Sexual Violence Survey (NISVS): 2015 Data Brief - Updated Release. Atlanta, Georgia. National Center for Injury Prevention and Control, Centers for Disease Control and Prevention. Retrieved from https://www.cdc.gov/violenceprevention/pdf/2015data-brief508.pdf.

Trouble Kaiketsu Detective Agency LLC. Koganei stalker attempted murder case. (2016) Retrieved from https://xn--lck1a7b2mb.jp/casefile_item/koganei

Trouble Kaiketsu Detective Agency LLC. Zushi Stalker murder case. (2012) Retrieved from https://xn--lck1a7b2mb.jp/casefile_item/zushi

Trouble Kaiketsu Detective Agency LLC. Okegawa Stalker murder case. (1999) Retrieved from https://xn--lck1a7b2mb.jp/casefile_item/okegawa 
Yoshimatsu, I. (2015) Fighting for new laws to protect women in Japan. [Video file]

Retrieved from http://www.tedxkyoto.com/events/tedxkyoto-2015/fighting-for-newlaws-to-protect-women-in-japan-ikumi-yoshimatsu-tedxkyoto. 


\title{
SOME ISSUES OF THE PROCEEDINGS UNDER ARTICLE 66 OF THE ADMINISTRATIVE PROCEDURE CODE IN THE CONTEXT OF THE ACTIVITY CARRIED OUT BY THE FARMERS
}

\author{
Svetlana Tsonchovska ${ }^{1}$ \\ ЗА НЯКОИ ВЪПРОСИ НА ПРОИЗВОДСТВОТО ПО ЧЛ. 66 ОТ \\ АДМИНИСТРАТИВНОПРОЦЕСУАЛНИЯ КОДЕКС В КОНТЕКСТА НА \\ ОСЪЩЕСТВЯВАНАТА ОТ ЗЕМЕДЕЛСКИТЕ ПРОИЗВОДИТЕЛИ ДЕЙНОСТ
}

\section{СВЕТЛАНА ЦОНЧОВСКА}

\begin{abstract}
The process of creating and approving the final dedicated layer of "Allowable Areas" is a complex factual set of administrative and procedural actions by the administration that assists farmers to declare their plots with which they want to participate in the relevant support campaign.

In view of the fact that the final order of the Minister of Agriculture, Food and Forestry is, by its legal nature, an individual administrative act which affects the rights and legitimate interests of individual farmers in the course of their activities to one degree or the other, it is also subject to of judicial review of its legality.

Keywords: administrative act, order, challenge

JEL Codes: $K 23$

\section{Въведение}

Министерството на земеделието, храните и горите създава в системата за идентификация на земеделските парцели специализиран слой "Площи, допустими за подпомагане", който включва площите в добро земеделско състояние в рамките на всеки физически блок, въз основа на критериите на Наредба № 5 от 10 март 2010г. за условията за допустимост за подпомагане на земеделските парцели по схеми за плащане на площ и за общите и регионални критерии за постоянни пасища. Съгласно чл. 16г, ал. 4 от Наредба № 105 от 22 август 2006 г. за условията и реда за създаване, поддържане, достьп и ползване на Интегрираната система за администриране и контрол - министьрьт на земеделието и храните одобрява със заповед окончателния специализиран слой "Площи в добро земеделско състояние", но като подзаконов нормативен акт, наредбата не може да урежда въпроси извън очертания със закона предмет - с нея не може да се създава първична уредба на правомощие на министьра на земеделието и храните, което не е предвидено в закона.
\end{abstract}

\footnotetext{
${ }^{1} \mathrm{PhD}$ Student in "Law and History" Faculty, South-West University "Neofit Rilski”, Blagoevgrad, tsonchovska@abv.bg ORCID iDhttps://orcid.org/0000-0001-6933-4699
}

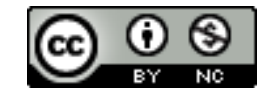

This work is licensed under a Creative Commons Attribution-NonCommercial 4.0 International License. 


\section{1.Правна уредба}

При нормотворчеството на текущото законодателство, както и на подзаконовите нормативни актове в различните социални сфери, съществено значение имат не само оправомощените субекти на законодателна инициатива, респ. държавните органи, реализиращи своята компетенция чрез издаването на юридически нормативни актове, но и неправителствените организации за защита на разнородните интереси на гражданите. Последните играят ролята на групи за натиск и/или групи по интереси, които „лобират“ за една или друга актуална обществена кауза (Мирчева, 2012). Това се отнася както до приемането на действащия понастоящем Административнопроцесуален кодекс (АПК, 2006), така и до откриването на производството по издаване на общи административни актове, което се оповестява публично чрез средствата за масово осведомяване, чрез изпращането на проекта до организации на заинтересованите лица или по друг подходящ начин (чл. 66, ал. 1 от АПК).

Съгласно чл. 16б, ал. 1, изр. 1 от Наредба № 105 от 22 август 2006 г. за условията и реда за създаване, поддържане, достъп и ползване на Интегрираната система за администриране и контрол (Наредба № 105, 2006), всяка година след приключване на обновяването по чл. 16а, ал. 2 Министерството на земеделието, храните и горите открива производство по чл. 66 от АПК за одобряване на изготвения слой.

\section{2. Производство по одобряване на изготвения специализиран слой „Площи, допустими за подпомагане}

От 2012 г. с измененията на Наредба № 105 (2006) и създаването на нов чл. 16б, всяка година след приключване на обновяването на слоя Министерството на земеделието и храните (сега Министерство на земеделието, храните и горите), открива производство по чл. 66 от АПК за одобряване на изготвения специализиран слой "Площи, допустими за подпомагане".

Откриването на производството се оповестява чрез:

1. публикуване на обява в един централен ежедневник;

2. публикуване на обявява на интернет страниците на Министерството на земеделието, храните и горите и на Дьржавен фонд "Земеделие" (ДФЗ);

3. изпращане на съобщения до браншови организации на земеделски стопани.

Уведомяването за откриване на производството включва:

a) на първо място основните съображения за изготвяне на специализирания слой "Площи, допустими за подпомагане";

б) на второ място възможността заинтересованите лица, т.е. земеделските стопани, кандидатстващи по отделните схеми, да се запознаят с изготвения специализиран слой в общинските служби по земеделие и в Областните дирекции "Дьржавен фонд "Земеделие" по местонахождение на площите и да подадат предложения и възражения за включване или невключване на определени физически блокове или части от тях в него ("Физически блок" е непрекъсната площ земя, ограничена от трайни топографски елементи).

Предвидена е възможност за земеделските стопани, а така също и за представителите на браншовите организации, представляващи определени земеделски стопани, в едномесечен срок от оповестяване на откриването на такова производството да се запознаят с включването в специализирания слой "Площи, допустими за подпомагане" на физическите блокове или частите от тях, в които стопанисват земеделски площи - чл. 16в, ал. 1 от Наредба № 105 (2006).

Реално самото запознаване би могло да се извърши в общинската служба по земеделие по местонахождението на площите, като за тази цел се използва сайтьт на 
ДФЗ, секция "Система за индивидуална справка по Директни плащания", чрез преглед на съответните физически блокове или части от тях върху Цифровата ортофото карта /ЦОФК/ и евентуално констатиране дали конкретните площи попадат в специализирания слой.

В случай, че земеделските стопани, респективно представителите на браншовите организации на земеделски стопани, констатират несъответствия, то същите биха могли в едномесечния срок да подадат своите предложения и възражения до министъра на земеделието, храните и горите по одобрен образец - чрез автоматично генериране в секция "Система за индивидуална справка по Директни плащания" от интернетстраницата на ДФ3, за включване, респективно невключване на определени физически блокове или части от тях в специализирания слой "Площи, допустими за подпомагане".

След изтичане на едномесечния срок и след извършване на проверки на получените предложения и възражения и отстраняване на установените пропуски и грешки Министерството на земеделието, храните и горите изготвя окончателен специализиран слой "Площи, допустими за подпомагане". Окончателният специализиран слой "Площи, допустими за подпомагане" се одобрява със заповед на министъра на земеделието, храните и горите и въз основа на него Разплащателна агенция извършва окончателна оторизация и плащания на площ за съответната стопанска година и приема заявления за подпомагане през следващата година - чл. 16г от Наредба № 105 (2006).

Заповедта на министьра на земеделието, храните и горите, с която се одобрява обхвата на специализирания слой, подлежи на оспорване по реда на Административнопроцесуалния кодекс пред Върховния административен съд (Хрусанов, 2002; Стоянов, 2009; Пенчев, Тодоров, Ангелов \& Йорданов, 2006).

\section{3. Тълкувателно дело № 1/2015 г.}

През 2015 г. по искане на Главния прокурор на Република България, отправено до Общото събрание на колегиите във Върховния административен съд, е образувано тълкувателно дело № 1/2015 г. за приемане на тълкувателно решение по въпрос относно характера на актовете на органите на ДФЗ - РА по чл. 26, ал. ал. 1, т. 3 и чл. 33 от Наредба № 9 от 2008 г. на министьра на земеделието и горите за условията и реда за предоставяне на безвъзмездна финансова помощ по мярка "Създаване на стопанства на млади фермери" по Програмата за развитие на селските райони за периода 2007 - 2013 г. (2008) и подлежат ли те на съдебно обжалване по реда на АПК.

С допълнително искане председателят на Върховния административен съд е поискал допълнително да се включи и втори въпрос, свързан с противоречивото прилагане на Закон за подпомагане на земеделските производители (ЗПЗП, 1998), а именно:

„Допустим ли е самостоятелен съдебен контрол на заповедта на министьра на земеделието и храните, издадена на основание чл. 16г, ал. 4 (предишна ал. 2) от Наредба № 105 от 22.08.2006 г. за условията и реда за създаване, поддържане, достъп и ползване на Интегрираната система за администриране и контрол (2006), с която се одобрява окончателният специализиран слой "Площи, допустими за подпомагане " като част от системата за идентификация на земеделските парцели?”.

Интерес представлява именно втория въпрос.

С Тълкувателно решение № 8 от 11.12.2015 г. Общото събрание на колегиите на Върховния административен съд се е произнесло по въпроса.

Съгласно мотивите на решението, Специализираният слой "Площи, допустими за подпомагане", чието наименование съгласно чл. 16г от Наредба № 105 (2006) преди 
изменението с ДВ, бр. 16/2015 г., е било специализиран слой "Площи в добро земеделско състояние", представлява геореферирана графична база данни за площите, допустими за подпомагане за съответната кампания, изграден на база ортофото и сателитни изображения за територията на страната. Тази електронна база е част от Системата за идентификация на земеделските парцели (СИЗП), която пък по силата на чл. 30, ал. 2, т. 2 от ЗПЗП (1998) е част от Интегрираната система за администриране и контрол (ИСАК). Специализираният слой се състои от площите, за които се счита, че отговарят на изискванията за подпомагане. Този слой се актуализира основно с използването на сателитни или самолетни изображения, от които е изготвена цифровата ортофото карта, а също така и чрез отразяване на резултати от теренни проверки на характеристики на физическите блокове.

По-нататък, съдиите от ВАС приемат, че в системата се включват данни от картата на възстановената собственост и регистрите към нея или от кадастралната карта и регистрите към нея. На основание чл. 30, ал. 4, т. 2 от ЗПЗП (1998) СИЗП се създава и поддържа от Министерството на земеделието и храните (сега Министерство на земеделието, храните и горите), като на основание чл. 33, ал. 2 от ЗПЗП (1998) министьрьт на земеделието и храните (сега министъра на земеделието, храните и горите) организира създаването и актуализирането на цифрова ортофото карта за територията на страната.

Съгласно чл. 16б, ал. 1, изр. 1 от Наредба № 105 (2006), всяка година след приключване на обновяването по чл. 16а, ал. 2 Министерството на земеделието, храните и горите открива производство по чл. 66 от АПК за одобряване на изготвения слой. Съдът приема се, че това производство представлява сложен фактически състав на процедура, провеждана от министъра на земеделието и храните чрез съответните областни дирекции "Земеделие", която завършва със заповед на министьра на земеделието и храните по чл. 16г, ал. 4 (предишна ал. 2) от Наредба № 105 (2006), с която се одобрява окончателният слой. Според поддържащите това становище тази заповед слага край на производството пред административния орган и с нея се създават съответните права за земеделските производители, свързани със заявените от тях за подпомагане земеделски площи, които попадат в одобрения окончателен слой.

Мнението на съдиите е, че решаващ в случая е правният ефект на административния акт - дали засяга субективни права или законни интереси на граждани или юридически лица, а в този случай, според тях, такова засягане е налице. По изложеното в тълкувателното решение от този критерий следва да се ръководят и съдилищата. Обосновават правото на съдебно обжалване на административния акт с разпоредбата на чл. 120, ал. 2 от Конституцията на Република България (1991) и Решение № 21 от 26 октомври 1995 г. по к. д. № 18/1995 г. за тълкуване на разпоредбата на чл. 120, ал. 2 от Конституцията (1991) на Конституционния съд (1995), според които подлежат на атакуване пред съдилищата всички административни актове, включително и тези, които по своя характер са вътрешнослужебни.

Друг аргумент на съда е, че производството по създаването и одобряването на окончателния слой представлява един сложен фактически състав от административнопроцесуални действия на администрацията, която подпомага земеделските стопани да заявят своите парцели, с които искат да участват в съответната кампания за подпомагане.

Именно за улеснение на земеделските стопани, ВАС е приел, че за тях е от решаващо значение дали стопанисваната земя е включена в слоя или не, тъй като от една страна това обуславя правото им да получат субсидии, а от друга - да не нарушат 
изискването за коректно заявяване на площите за подпомагане и свързаното с това евентуално санкциониране.

Ето защо заповедта на министьра, издадена на основание чл. 16г, ал. 4 (предишна ал. 2) от Наредба № 105 (2006), е акт, с който се засягат конкретни права и законни интереси на земеделския производител, и този акт подлежи на съдебен контрол за законосъобразност. Това е така, тъй като тази заповед слага край на производството пред административния орган - министьра на земеделието, храните и горите. С нея се създават съответните права за земеделските производители, свързани със заявените от тях за подпомагане земеделски земи, които попадат или не в одобрения окончателен слой. Посоченото по-горе води до извод, че по отношение на отделния земеделски производител заповедта е индивидуален административен акт (Сивков \& Зиновиева, et al., 2015). Тя има непосредствено значение за него и от нея зависи възникването и упражняването на правото на подпомагане по схемите и мерките за подпомагане, посочени в ЗПЗП (1998). По своя характер тази заповед съставлява сьвкупност от множество индивидуални административни актове. Тя има конкретно определено съдържание и засяга единствено отделните лица, претендиращи право на подпомагане въ3 основа на един или повече имоти, включени или не в същата. Производството по оспорване на заповедта следва да се проведе по реда на АПК - „глава десета“ - раздел I - „Оспорване на индивидуални административни актове“ (2006).

Върховния административен съд сочи още, че освен това, съдебно обжалване на заповедта на министъра не е изключено с изрична законова разпоредба, а това означава, че административният акт може да бъде обжалван по силата на чл. 120, ал. 2 от Конституцията (в този смисъл е и Решение № 21 от 26 октомври 1995 г. по к. д. № 18/1995 г. за тълкуване на разпоредбата на чл. 120, ал. 2 от Конституцията (1991) на Конституционния съд (1995), съгласно което подлежат на атакуване пред съдилищата всички административни актове, с които се засягат права и интереси на граждани и юридически лица. Със заповедта пряко се засягат правата на земеделските производители във връзка с включването в допустимия слой на всички заявени от тях земи, респективно с неуважаването на направените от тях възражения по заповедта на основание чл. 16б, ал. 1 от Наредба № 105 (2006). Тази заповед се явява окончателният завършващ акт на проведената процедура пред министъра на земеделието и храните, поради което подлежи на съдебен контрол за законосъобразност.

Нещо повече, за да функционира Разплащателната агенция, тя действа в условията на обвързана компетентност и няма как да извърши окончателна оторизация и плащания на площ за съответната година и да приеме заявление за подпомагане през следващата година, ако парцельт на съответното лице не е включен в заповедта по чл. 16г, ал. 4 от Наредба № 105 (2006). Това е и причината, обосноваваща прекия и непосредствен правен интерес на земеделския производител да оспорва заповедта (Трифонова, 2015).

Предвид гореизложеното, Общото събрание на колегиите на Върховния административен съд, е приел, че е ,допустим сьдебен контрол на заповедта на министьра на земеделието и храните, издадена на основание чл. 16г, ал. 4 (предишна ал. 2) от Наредба № 105 от 22.08.2006 г. за условията и реда за създаване, поддържане, достып и ползване на Интегрираната система за администриране и контрол, с която се одобрява окончателният специализиран слой "Площи в добро земеделско състояние“.

Тълкувателното решение е подписано с особено мнение от десет съдии, които приемат, че заповедта на министьра на земеделието и храните, с която се одобрява окончателният слой, не представлява административен акт, с който пряко се създават 
или засягат права и интереси на отделните субекти. По силата на тази заповед не настъпва непосредствено промяна в правната сфера на кандидатите за подпомагане, а се извършва обновяване на информацията, съдържаща се в СИЗП. Възможността за подаване на възражения и предложения от земеделските производители, преди да бъде одобрен окончателният слой, не може да служи като аргумент за тезата, че със заповедта на министьра пряко се засягат техни права или законни интереси (Стоянов, 2009).

Ето защо, те застьпват тезата, че не настьпва промяна в правната сфера на кандидата за подпомагане, а се извършва обновяване на информацията, съдържаща се в СИЗП, т.е. тази заповед е насочена само към длъжностните лица, поддържащи тази система и същата не подлежи на съдебен контрол.

\section{Заключение}

По изложените от Върховния административен съд съобржения, и предвид характера на заповедта, която по своята правна същност, според мен, представлява индивидуален административен акт, то становището ми е, че същата следва да подлежи на съдебен контрол по реда на Глава десета от АПК. 


\section{Библиография}

Hrusanov, D. (2002). Osporvane na administrativnite aktove. Sofia: Sibi

[Хрусанов, Д. (2002). Оспорване на административните актове. София: Сиби].

Mircheva, V. (2012) Lobizmat - efektiven mehanizam za zashtita interesite na grajdanite, V: Naukata, obrazovanieto I izkustvoto prez 21 vek. Godishnik, tom IV, I chast, Blagoevgrad: Sayuz na uchenite, klon Blagoevgrad. [Мирчева, В. (2012) Лобизмът - ефективен механизъм за защита интересите на гражданите, В: Науката, образованието и изкуството през 21 век, Годишник, том IV, I част, Благоевград: Съюз на учените, клон-Благоевград.]

Penchev, K., I. Todorov, G. Angelov, B. Yordanov. (2006). Komentar na administrativno protsesualnia kodeks. Sofia: Siela. [Пенчев, К., И. Тодоров, Г. Ангелов, Б. Йорданов (2006). Коментар на административно проиесуалния кодекс. София: Сиела].

Sivkov, Ts., D. Zinovieva, G. Dimitrov, E. Panayotova, R. Nikolova, S. Yankulova, G. Cherneva, K. Milcheva. (2015). Administrativno pravo. Spetsialna chast. kurs lektsii. Sofia: Sibi. [Сивков, Ц., Д. Зиновиева, Г. Димитров, Е. Панайотова, Р. Николова, С. Янкулова, Г. Чернева, К. Милчева (2015). Административно право. Специална част. курс лекции. София: Сиби].

Stoyanov, E. (2009). Sadebniyat kontrol varhu individualnite administrativni aktove. Sofia: Siela. [Стоянов, Е. (2009). Съдебният контрол върху индивидуалните административни актове. София: Сиела].

Trifonova, D. (2015). Spetsifiki na administrativnoto proizvodstvo i dogovaryaneto pri usvoyavaneto na sredstvata ot ES. sp.,Praven svyat”, br. 4. [Трифонова, Д. (2015). Специфики на административното производство и договарянето при усвояването на средствата от ЕС. сп.,Правен свят", бр. 4].

\section{Нормативни актове и решения}

Administrativnoprotsesualen koeks (2006). [Административнопроцесуален кодекс] Retrieved from: https://www.lex.bg/laws/ldoc/2135521015.

Konstitutsiya na Republika Balgariya (1991). [Конституция на Република България] Retrieved from: https://www.parliament.bg/bg/const.

Naredba № 5 ot 10 mart 2010 g. za usloviyata za dopustimost za podpomagane na zemedelskite partseli po shemi za plashtane na plosht I za obshtite I regionalni kriterii za postoyanni pasishta (2010). [Наредба № 5 от 10 март 2010 г. за условията за допустимост за подпомагане на земеделските парцели по схеми за плащане на площ и за общите и регионални критерии за постоянни пасища (2010)] Retrieved from https://www.dfz.bg/assets/6185/55555_9.pdf.

Naredba № 9 ot 2008 g. na ministara na zemedelieto I gorite za usloviyata I reda za predostavyane na bezvazmezdna finansova pomosht po myarka "Sazdavane na stopanstva na mladi fermeri" po Programa za razvitie na selskite raioni za perioda 2007 - 2013 g. (2008). [Наредба № 9 от 2008 г. на министьра на земеделието и горите за условията и реда за предоставяне на безвъзмездна финансова помощ по мярка "Създаване на стопанства на млади фермери" по Програмата за 
развитие на селските райони за периода 2007 - 2013 г.] Retrieved from: https://www.dfz.bg/assets/51/NAREDBA_9_ot_3042008_g_za_usloviqta_i_reda_za predostavqne_na_bezvyzmezdna_finansova_pomos_po_mqrka_pdf.

Naredba № 105 ot 22 avgust 2006 g. za usloviyata I reda za sazdavane, poddarzhane, dostap I polzvane na Integriranata sistema za administrirane I kontrol (2006). [Наредба № 105 от 22 август 2006 г. за условията и реда за създаване, поддържане, достъп и ползване на Интегрираната система за администриране и контрол] Retrieved from: https://www.mzh.government.bg/odzplovdiv/Libraries/\%D0\%9D\%D0\%B0\%D1\%80\%D0\%B5\%D0\%B4\%D0\%B1\%D0\% B8/105_22_08_2006.sflb.ashx.

Reshenie № 21 ot 26 oktomvri 1995 g. po k. d. № 18/1995 za talkuvane na razporedbata na chl. 120, al. 2 ot Konstitutsiyata (1991) na Konstitutsionniya sad (1995). [Решение № 21 от 26 октомври 1995 г. по к. д. № 18/1995 г. за тълкуване на разпоредбата на чл. 120, ал. 2 от Конституцията (1991) на Конституционния съд (1995)] Retrieved from: http://www.constcourt.bg/bg/Acts/GetHtmlContent/e39376f0-507d-4de9-929438c567ae0263.

Talkuvatelno reshenie № 8 ot 11.12.2015 g. na Obshtoto sabranie na kolegiite na Varhovniya administrativen sad (2015). [Тълкувателно решение № 8 от 11.12.2015 г. на Общото събрание на колегиите на Върховния административен съд (2015)] Retrieved from:

http://www.sac.government.bg/TD_VAS.nsf/d038edcf49190344c2256b7600367606/ b6e9f1260b3b3521c2257f0e00309723? OpenDocument.

Zakon za podpomagane na zemedelskite proizvoditeli (1998). [Закон за подпомагане на земеделските производители] Retrieved from: https://www.lex.bg/laws/ldoc/2134406656. 